EVELYN ROBERTA ARAÚJO BARRETO DE SOUZA

\title{
A ATUALIDADE DOS PROJETOS DE PAZ PERPÉTUA NO DIREITO INTERNACIONAL CONTEMPORÂNEO
}

\author{
DisSertaÇÃo de MeSTRAdo \\ Orientadora: Profa. Associada Dra. Cláudia Perrone Moisés
}

FACULDADE DE DIREITO DA UNIVERSIDADE DE SÃO PAULO SÃO PAULO 2013 


\title{
EVELYN ROBERTA ARAÚJO BARRETO DE SOUZA
}

\section{A ATUALIDADE DOS PROJETOS DE PAZ PERPÉTUA NO DIREITO INTERNACIONAL CONTEMPORÂNEO}

\author{
Dissertação de Mestrado apresentada à Banca \\ Examinadora, no âmbito do Programa de Pós- \\ Graduação da Faculdade de Direito da Universidade de \\ São Paulo, como exigência parcial para a obtenção do \\ título de Mestre em Direito Internacional e Comparado, \\ sob orientação da Professora Associada Doutora Cláudia \\ Perrone Moisés.
}

Versão corrigida em 11 de novembro de 2013. A versão original, em formato eletrônico (PDF), encontra-se disponível na Comissão de Pós-Graduação da Unidade

\section{FACULDADE DE DIREITO DA UNIVERSIDADE DE SÃO PAULO SÃO PAULO}


FOLHA DE APROVAÇÃO

Evelyn Roberta Araújo Barreto de Souza

\section{A ATUALIDADE DOS PROJETOS DE PAZ PERPÉTUA NO DIREITO INTERNACIONAL CONTEMPORÂNEO}

Aprovada em: 16/09/2013

\section{Banca Examinadora}

Professora Associada Dra. Cláudia Perrone Moisés Instituição: Universidade de São Paulo-USP

Assinatura:

Professora Dra Liliana Lyra Jubilut

Instituição: Universidade Católica de Santos-UNISANTOS

Assinatura:

Professor Associado Dr. Gustavo Ferraz de Campos Monaco Instituição: Universidade de São Paulo-USP

Assinatura: 
À minha querida mãe, LEONOR, pelo amor incondicional, pela sublime vocação da maternidade $e$ pelo incentivo entusiasta e inabalável em todos os meus projetos, sejam eles de "paz perpétua" ou não, desde sempre...

Para BRUNO, pelo privilégio de tê-lo como irmão e por ser, ao seu modo particular, o mais perto de moral kantiana que conheço;

À VÓ TININHA, in memoriam, "minha deusa lar", lá em cima muito feliz por mais um passo dado de sua neta;

Por fim, a todos aqueles que por atos, palavras ou pensamentos contribuem de alguma forma para a perpétua construção da paz no mundo. 


\section{AGRADECIMENTOS}

Antes de tudo, agradeço a Professora Associada Dra. Cláudia PerroneMoisés, por ter profetizado que eu seria sua "orientanda do coração". A ela, agradeço pelas preciosas aulas e discussões filosóficas que serviram de grande inspiração em minhas pesquisas sobre a temática kantiana no direito internacional. Pela compreensão e confiança no presente trabalho e principalmente por me devolver o gosto e a crença na vida acadêmica: muito obrigada!

Agradeço, ao Professor Titular de Direito do Trabalho da Universidade de São Paulo, Dr. Cássio Mesquita Barros, representante do Brasil na OIT por 16 (dezesseis anos), que me permitiu conhecer, mesmo que de forma reflexa no âmbito de minha atuação profissional, a importância in concreto de uma Organização Internacional e dos estudos dos diferentes ordenamentos jurídicos na seara do Direito Comparado.

Não poderia deixar de fazer um agradecimento especial, aos funcionários da Secretaria da Pós-Graduação e do Departamento de Direito Internacional e Comparado da Faculdade de Direito da Universidade de São Paulo, citando as atenciosas e solícitas Fátima Cortinhal, Cláudia Koga e Fernanda Targino.

Agradeço aos colegas dos bancos acadêmicos da Faculdade de Direito da Universidade de São Paulo, em especial a Renata Nagamine, Gabriela Saab e Luiz Ricardo Miranda e ao querido amigo Luiz Fabrício Thaumaturgo Vergueiro, companheiro na Academia de Direito Internacional da Haia, que tanto colaboraram com sugestões, críticas e materiais de estudo e pesquisa na reta final de conclusão do trabalho.

Agradeço imensamente à Cristiane Nogaroto Pinheiro, dileta amiga e sócia, pela compreensão, paciência e principalmente pelo "pronto atendimento" nas questões de informática durante todo período do programa de mestrado e ao Dr. Elson Ferreira Junior, “o querido vizinho" pela hábil resolução das questões burocráticas com as quais me deparei algumas vezes ao longo do mestrado. 


\section{A Lucas Anielo Scarapicchia, Rodrigo Miranda, Paulo Arthur Coelho,}

Vagner Araújo e Ioná Bacht, cujos laços de amizade transbordaram os portões da Rua Maria Antônia e as reuniões do grupo de estudos de Direito Internacional do Mackenzie, pelo constante apoio e carinho para com a minha pessoa, nos momentos difíceis dessa caminhada que ora chega ao fim.

Agradeço também, aos queridos tios, Jean Carlos de Souza e Maria Angélica Silva Souza (tia Kali), família com quem sempre pude contar, pelas palavras e gestos de acalanto nesta e em todas as outras etapas de minha vida, inclusive nas que estão ainda para se iniciar.

Por fim e não menos importante, agradeço a todos colegas, amigos e familiares de cuja companhia me afastei durante o período de estudos, mas que independentemente da reciprocidade, de uma forma ou de outra se fizeram presente em minha vida. 
“(...) pressionados por seu próprio risco, embora sem consideração legal, eles se oferecem como árbitros e desse modo preparam com antecedência um futuro grande corpo político (Staatskörper), do qual o passado não deu nenhum exemplo. Embora este corpo político (Staatskörper) por enquanto seja somente um esboço grosseiro, começa a despertar em todos os seus membros como que um sentimento: a importância da manutenção do todo; e isto traz a esperança de que, depois de várias revoluções $e$ transformações, finalmente poderá ser realizado um dia aquilo que a natureza tem como propósito supremo, um Estado cosmopolita universal, como o seio no qual podem se desenvolver todas as disposições originais da espécie humana." (Kant Ideia de uma História Universal de um Ponto de Vista Cosmopolita) 


\section{RESUMO}

O presente trabalho argumenta, primordialmente, que a Organização das Nações Unidas e, antes dela, a Liga das Nações seriam traduções, na prática, de ideias modernas para a construção da paz. Na tradição do pensamento ocidental em que essas ideias se inscrevem, destacam-se o sistema da teoria da paz no pensamento kantiano, sobretudo, as ideias reunidas no projeto de paz perpétua de Kant. O trabalho se assenta sobre o pressuposto de que há uma correlação do projeto desenvolvido por Kant e o direito internacional contemporâneo, da qual seriam mostras as Organizações Internacionais. Já por força desse pressuposto, o seu tema seria relevante por estar inscrito na gênese do direito internacional.

Palavras-chave: Projeto de paz perpétua. Institucionalização da paz. Direito internacional contemporâneo. Organização das Nações Unidas. 


\begin{abstract}
This dissertation argues, basically, that the UN and the League of Nations, before it, translate into practice modern ideas to the construction of peace. In the tradition of the modern thought, in which these ideas are inscribed, it highlights the Kantian system of the theory of peace, above all, the ideas collected in the project of perpetual peace of Kant. The dissertation presupposes that there is a correlation between the project elaborated by Kant and contemporary international law, of whom the international organizations would be clear signs. Already by force of this understanding, its theme would be inscribed in the genesis of international law.
\end{abstract}

Keywords: Project of perpetual peace. Institutionalization of peace. Contemporary international law. United Nations Organization 


\title{
LISTA DE ABREVIATURAS
}

\author{
a.C. - antes de Cristo \\ AG - Assembleia Geral \\ CS - Conselho de Segurança \\ d.C. - depois de Cristo \\ OI - Organização Internacional \\ OIS - Organizações Internacionais \\ ONU - Organização das Nações Unidas \\ SdN - Sociedade das Nações
}

UNESCO - Organização das Nações Unidas para a Educação, a Ciência e a Cultura 


\section{SUMÁRIO}

INTRODUÇÃO 12

\section{CAPÍTULO 1. FUNDAMENTOS TEÓRICOS DO DIREITO INTERNACIONAL} COMO ANTECEDENTES HISTÓRICOS DOS PROJETOS DE “PAZ PERPÉTUA"

1.1. Os precursores do direito internacional: as doutrinas clássicas.......................39

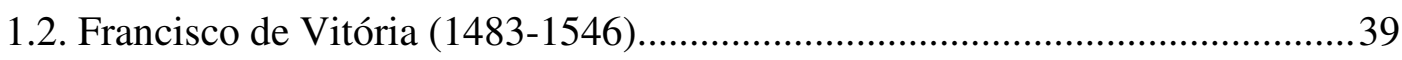

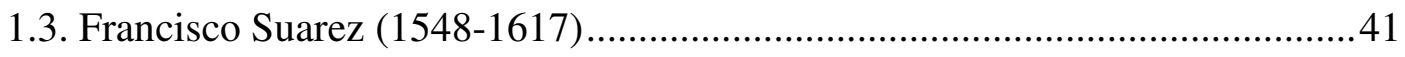

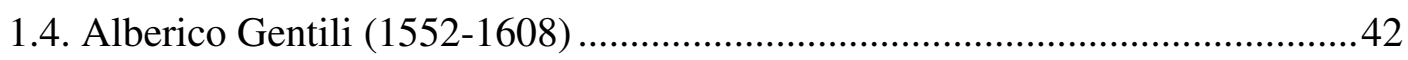

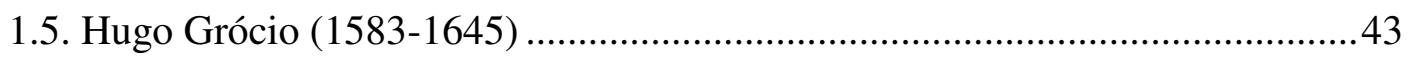

\section{CAPÍtUlO 2. A TRADIÇÃO DOS PROJETOS DE "PAZ PERPÉTUA" NO} PENSAMENTO OCIDENTAL

2.1. William Penn: "Ensaio para uma paz presente e futura da Europa por meio da fundação de uma Assembleia, um Parlamento ou uma Câmara de Estados da Europa" .54

2.2. Abbé de Saint-Pierre: "Projeto para tornar perpétua a paz na Europa". .62

2.3. Jean-Jacques Rousseau: "Extrato e Julgamento do Projeto de Paz Perpétua de Abbé de Saint-Pierre"

3.1. Breve introdução ao pensamento kantiano: critérios morais e racionais na investigação da paz

3.2. Apresentação da estrutura do projeto .79

3.2.1. Análise dos artigos preliminares 81

3.2.2. Análise dos artigos definitivos 84

3.2.3. A garantia e o artigo secreto para uma paz perpétua futura 85

3.2.4. A discussão sobre a moral e a política na paz: os apensos 87 


\section{CAPÍTULO 4. O PROJETO DE PAZ DE KANT E O DIREITO INTERNACIONAL}

CONTEMPORÂNEO

4.1. Alguns apontamentos atuais sobre a influência dos elementos kantianos no direito internacional

4.2. O direito cosmopolita kantiano: um estudo do terceiro artigo definitivo e sua influência no direito internacional contemporâneo

CAPÍtUlO 5. A BUSCA DA PAZ PERPÉtUA NA ATUALIDAdE: AS ORGANIZAÇÕES INTERNACIONAIS

5.1. O direito internacional contemporâneo e a realização institucional da paz .....95

5.1.1. Da Liga das Nações à Organização das Nações Unidas.........................96

5.2. Assembleia Geral da ONU como reflexo do pensamento de paz kantiano.... 100

CONCLUSÃO 103

REFERÊNCIAS 106

\section{ANEXO - ILUSTRAÇÃO}

I. MAPA DE REORGANIZAÇÃO DA EUROPA DO DUQUE DE SULLY (MAXIMILIEN DE BETHUNE)

\section{APÊNDICE}

I. TÉCNICAS PARA UMA ALTERAÇÃO DA DISPOSIÇÃO HUMANA EM PROL DA PAZ MUNDIAL POR CARL GUSTAV JUNG: RESPOSTA A UMA SOLICITAÇÃO DA UNESCO EM 1948. 


\title{
INTRODUÇÃO
}

\begin{abstract}
"A construção da paz e a durabilidade desta, como premissas de ordenação humana do mundo: cabe enfatizar, de ordenação teleologicamente humana do mundo! Tão fácil de se desejar, como complexo para se construir". (Paulo Borba Casella)
\end{abstract}

Nas primeiras linhas de "The Changing Structure of International Law", FRIEDMANN, conecta de maneira inexorável o direito, a sociedade e a história. A partir dessa conexão estabelecida, somos levados a crer que o estudo do direito, particularmente do direito internacional, não pode prescindir do elemento histórico.

Sob esse prisma, interessante observar que a percepção do direito internacional como produto de seu tempo e meio cultural não é nova. Nesse exato sentido, cabe citar Serge A. Baron Korff $(1923)^{2}$ e Otfried Nippold (1924) ${ }^{3}$, dentre os primeiros a utilizar a abordagem mencionada em seus cursos na Academia de Direito Internacional em Haia. ${ }^{4}$

Pois bem, como se pode inferir, as ideias podem ter curso durante séculos, como é exemplo o ideal da construção da paz no direito internacional, objeto de estudo do presente trabalho, até vir esse ideal traduzir-se na prática ${ }^{5}$.

A pertinência do tema reside no fato de que a investigação acerca do estabelecimento de uma paz no mundo, como se pretende encetar, é certamente umas das ideias mais antigas da humanidade e ao mesmo tempo uma preocupação constante e atual, conforme bem assevera Casella, no trecho em destaque.

\footnotetext{
${ }^{1}$ FRIEDMANN, Wolfgang. The changing structure of international law. New York: Columbia University Press, 1964. p. 7.

${ }^{2}$ KORFF, Serge A. Introduction à l'histoire du droit international. Recueil des Cours, Haye, v. 1, p. 5-23, 1923. (Collected Courses of The Hague Academy of International Law).

${ }^{3}$ DU NIPPOLD, O. Le développement historique droit international depuis le Congrès de Vienne. Recueil des Cours, Haye, v. 1, n. 2, p. 1-121, 1924. (Collected Courses of The Hague Academy of International Law).

${ }^{4}$ CASELLA, Paulo Borba. Fundamentos do direito internacional pós-moderno. São Paulo: Quartier Latin, 2008. p. 450.

${ }^{5}$ Id. Ibid., p. 212.
} 
"A tradução do ideal de construção da paz na Europa, na linha de Charles Irénée Castel, dito o Abbé de SAINT-PIERRE, comentado por $G$. W. LEIBNIZ. Foi retomado e anotado por Jean-Jacques ROUSSEAU, embora fosse este bastante cético em relação ao direito internacional, como também pelo enciclopedista D'ALEMBERT, antes de ser levado à formulação definitiva por Immanuel KANT. Desde o final do século XVIII, percorre, ao longo do tempo, seu tortuoso caminho, passa inclusive por Max SCHELER (1931), até o bicentenário da formulação kantiana, conforme examina Jürgen HABERMAS (1995)" .

Tendo em vista a finalidade desta pesquisa, cabe agora de forma introdutória discorrer acerca do sentido da simbólica da paz que a humanidade, no decorrer da história ocidental, procurou construir.

Entendemos por simbólica da paz o conjunto de expressões, discursos, mitos e ritos cotidianos, por meio dos quais a humanidade buscou expressar sua valoração acerca do conceito de paz.

Todavia, orientados pelo nosso propósito temático e sobremaneira seu espectro, optamos por definir exordialmente, a simbólica da paz como a expressão da autoconsciência do ser humano em relação ao seu convívio em sociedade, imprimindo à noção do conceito de "paz" uma conotação de serenidade, tranquilidade e concórdia entre os povos.

Em sequência, apresentaremos de forma sintética, um iter da construção da paz na tradição grega e alguns apontamentos sobre o seu tratamento na modernidade ${ }^{7}$.

Na perspectiva da tradição mitológica grega, Hesíodo apresenta no poema épico $^{8}$ Teogonia $^{9}$, a deusa Eirene, Paz, como uma das três Horas $^{10}$. As outras duas são a Eunomia $^{11}$, Ordem ou Disciplina e a Diké, Justiça. As Horas na mitologia grega são divindades da natureza, que tem por função assegurar o equilíbrio da vida em

${ }^{6}$ CASELLA, Paulo Borba. op. cit., p. 212-214.

${ }^{7} \mathrm{O}$ conceito de paz na modernidade bem como no Medievo, será retomado de forma mais minuciosa no primeiro capítulo do trabalho.

${ }^{8}$ A Teogonia teria sido escrita por volta de 700 a.C.

${ }^{9}$ Transliteração para “Genealogia dos Deuses". Do grego theogonia: theos (deus) + genea (origem).

${ }^{10}$ As Horas são deusas filhas de Têmis e de Zeus.

${ }^{11}$ Importante dizer, que apesar da distinção de significado dos vocábulos, em algumas traduções encontramos a deusa Eunomia como Equidade. 
sociedade. Moradora do Olimpo, Eirene era perseguida por Ares, o deus grego que personifica a guerra.

Eirene, também conhecida como a "deusa dos frutos", era representada tendo em suas mãos um ramo de oliveira, ou o menino Plutão, deus da riqueza, ou um caduceu (espécie de archote virado para baixo com espigas de trigo) ou ainda uma cornucópia (vaso em forma de chifre com frutos e flores).

Fácil perceber ante as múltiplas representações da "deusa da paz" grega, acima mencionadas, tratar-se de um símbolo que evoca prosperidade, abundância e fartura.

Em 371 a. C, ano da celebração do tratado de paz que pôs fim aos conflitos entre Atenas e Esparta, uma estátua de bronze de Eirene foi erguida na praça do mercado de Atenas, local de grande circulação. Infere-se pela escolha do local, a função de protetora e guardiã da polis grega que é atribuída a essa deusa pelos gregos antigos.

Ato contínuo, com esfacelamento da cristandade medieval, os fundamentos religiosos e místicos sucumbem ante a necessidade de uma justificativa não religiosa da aspiração da humanidade à paz.

Em adição, o surgimento dos Estados nacionais e o aparecimento da racionalidade moderna, são fatores que contribuíram para redimensionar a simbólica da paz no ocidente.

Em especial no período do Iluminismo, autores começam a pesquisar os pilares teóricos de uma ordem de paz baseada na razão. Em seu dizer, Casella novamente enuncia.

"Foi no tempo do Iluminismo que se cria a história do direito internacional como novo campo de estudo, ainda relutante em chamálo de ciência. Trata-se da conscientização do trajeto já percorrido, a preparar o caminho para o futuro: a construção da utopia, com a multiplicação das formulações dos projetos para tornar perpétua a paz na Europa - do Abbé de SAINT-PIERRE 1713) a Immanuel KANT, no Ensaio sobre a paz perpétua (1795), com vários autores, entre esses dois marcos, ao longo do século XVIII ${ }^{22 " .}$

\footnotetext{
${ }^{12}$ ACCIOLY, Hildebrando; SILVA, Geraldo Eulálio do Nascimento e; CASELLA, Paulo Borba. Manual de direito internacional público. 17. ed. São Paulo: Saraiva, 2009. p. 47.
} 
Sob esse enfoque, introduz-se como método reflexivo teórico da investigação da paz, no âmbito do direito e da filosofia, uma tradição de vários projetos para estabelecer ou manter a paz no mundo ocidental.

Assim, o primeiro capítulo do trabalho procura mostrar, mesmo que sinteticamente, o fluxo histórico do Direito Internacional Público; no sentido de afirmar a existência de um direito internacional é inerente à figura de um Estado soberano institucionalizado.

Nesse sentido, o capítulo traz alguns apontamentos sobre o "Direito das Gentes", que tende a evocar um sentido muito mais amplo do que a própria designação “direito internacional". À medida que, revela a noção de um direito comum a todas "as gentes", independente da necessidade de uma coletividade organizada (Estados), recaindo na tônica contemporânea dos indivíduos como novos sujeitos do Direito Internacional.

Outrossim, o capítulo vestibular busca consignar a importância de determinadas correntes filosóficas e conceitos que auxiliaram posteriormente para a elaboração dos projetos de paz perpétua. Em especial a elaboração do conceito de direito natural enunciado pela "escola estóica” de Zenão de Cítio, no século III a. C..

Busca também, introduzir institutos jurídicos próprios do direito internacional, tais como a Arbitragem, mecanismo de solução de conflitos extremamente utilizado nos projetos de paz perpétua, como se verá, a diplomacia, as Embaixadas e os Consulados.

Por fim, o primeiro capítulo disserta sobre alguns autores ditos como os precursores do Direito Internacional Público como disciplina autônoma.

O segundo capítulo do trabalho, apresenta alguns projetos de paz perpétua, com ênfase nos projetos oriundos do século XVIII, pois nesse século, pareceu-nos ser quase uma obsessão a busca pela paz e a consequente titulação nas pesquisas e obras publicadas com a adjetivação de "perpétua", como se verá.

Acerca desse capítulo, importante tecer algumas ponderações sobre a escolha dos projetos apresentados. 
A escolha, em um primeiro momento, pautou-se em dois aspectos: no fluxo temporal dos projetos e na raridade dos textos em português. Dois dos autores e projetos apresentados no trabalho, William Penn e Emeric Crucé, são praticamente desconhecidos no Brasil.

Deixando-se desde já consignado, de que não se fará uma análise exegética dos textos. Até porque nos dois casos acima mencionados, o que se fez foi uma tradução para o idioma pátrio, buscando ao máximo manter-se a ideia trazida nas versões originais, ou seja, no inglês e no francês respectivamente.

Far-se-á sim, uma apresentação dos objetivos dos projetos com a preocupação de trazer à tona algumas contribuições teóricas, filosóficas ou políticas para o desenvolvimento sistemático da investigação da paz no direito internacional.

Esclareça-se ainda, que o capítulo, tem por condão servir de arcabouço teórico, para a teoria de paz perpétua no pensamento de Kant, que será objeto de capítulo próprio e sequente.

Ainda nesse sentido, há uma apresentação dos projetos do Abbé de SaintPierre e Rousseau, corroborando do entendimento de Soromenho-Marques, para quem a pugna kantiana pela paz, parece num primeiro momento, conjugar alguns elementos das reflexões setecentistas, tais como as apresentadas pelos dois autores ${ }^{13}$.

Nessa concepção, entendemos que para além de repisar os argumentos setecentistas de seus antecessores, Kant avança na elaboração não para mais um projeto de paz ordinário, mas sim, conforme podemos depreender nos dicionários filosóficos de uso corrente, o filósofo caminha para um verdadeiro sistema da teoria de paz na modernidade.

A estrada tracejada por Kant transporta o leitor no sentido de que a paz perpétua é a síntese do múltiplo, numa unidade articulada em um todo orgânico, motivo pelo qual, o projeto de paz perpétua do autor foi analisado de forma destacada no terceiro capítulo.

\footnotetext{
${ }^{13}$ MARQUES, Viriato Soromenho. História e política no pensamento de Kant. Portugal: Publicações Europa-América, 1994. p. 92.
} 
Por esse motivo, resta imprescindível, mesmo que brevemente, uma introdução ao pensamento kantiano que encontra lugar no início do terceiro capítulo, que em verdade, é o centro norteador de todo o trabalho.

Desta feita, o capítulo "Kant e um projeto filosófico para a paz perpétua”, foi dividido e ponderado de forma compartimentada dos demais projetos.

No tocante a análise do projeto kantiano em si mesmo, o terceiro capítulo ainda traz num segundo momento, uma divisão binária de estrutura e de conteúdo, por meio de uma análise compartimentada dos seis artigos preliminares e dos três artigos definitivos aptos a instituir a paz entre os Estados.

Cumpre ainda dizer, que ao final do capítulo, apresenta-se a discussão sobre a moral e política na paz pela apresentação dos apensos. E também, a digressão sobre uma possível garantia e o artigo secreto para uma paz perpétua futura.

Em retrospectiva, a pesquisa em tela, procura estabelecer a correlação da atualidade dos projetos de paz perpétua no direito internacional contemporâneo, por meio da eleição do projeto kantiano à luz da tarefa da institucionalização da paz.

A seguir, o quarto capítulo traz à baila o debate hodierno da tridimensionalidade kantiana, consubstanciada nas palavras de Soraya Nour.

"O direito, até Kant, tinha duas dimensões (...) em uma nota de rodapé na Paz perpétua, Kant acrescenta uma terceira dimensão: o direito cosmopolita, direito dos cidadãos do mundo, que considera cada individuo não membro de seu Estado, mas membro, ao lado de cada Estado, de uma sociedade cosmopolita" ${ }^{14}$.

Pretende-se, ao término desse capítulo, constatar de forma delimitada, as três dimensões do direito no "Projeto de Paz Perpétua" do filósofo de Königsberg: o jus civitatis do direito interno; o jus gentium do direito internacional público que rege as relações dos Estados entre si; e o jus cosmopoliticum, o direito cosmopolita que diz

\footnotetext{
${ }^{14}$ NOUR, Soraya. À paz perpétua de Kant: filosofia do direito internacional e das relações internacionais. São Paulo: Martins Fontes, 2004. p. 54-55.
} 
respeito aos homens e Estados em suas relações exteriores e sua interdependência como cidadãos de um Estado universal da humanidade.

A fim de responder os anseios da busca da paz perpétua na contemporaneidade, o quinto e último capítulo tece uma consideração sobre o percurso histórico da realização institucional da paz no desenvolvimento das Organizações Internacionais no direito internacional atual.

Sob esse influxo, especial destaque será dado em duas tentativas; a experiência da Liga das Nações e a fundação na Organização das Nações Unidas.

No âmbito da ONU, será comentada a influência do pensamento kantiano através da atuação da Assembleia Geral, inclusive em sua competência residual para recomendar medidas que possibilitem manter ou restabelecer a paz; e em menor grau; com o Conselho de Segurança que é o órgão de competência originária.

Por fim, há no trabalho um anexo que traz a ilustração de um "Mapa de reorganização da Europa”, pensado por Duque de Sully em seu projeto de paz perpétua. Além de um apêndice sobre as técnicas para uma alteração da disposição humana da paz mundial, elaborado à pedido da UNESCO em 1948, por Carl Gustav Jung.

Busca-se colocar em debate, no presente trabalho, o fato de que Kant não se limitar apenas e tão somente a elaboração de um projeto de paz; segundo aponta Sérgio Viera de Mello "ele nos propõe, há dois séculos, o esboço de um verdadeiro edifício conceitual e de uma estrutura empírica capazes de superar contingência e conflito e instaurar relações de confiança e cooperação entre as nações" ${ }^{15}$.

\footnotetext{
${ }^{15}$ MELLO, Sérgio Vieira de. A consciência do mundo: a ONU diante do irracional na História. In: MARCOVITCH, Jacques (Org.). Sérgio Vieira de Mello: pensamento e memória. 1. ed. São Paulo: Saraiva, 2004. p. 47.
} 


\section{CAPÍTULO 1. FUNDAMENTOS TEÓRICOS DO DIREITO INTERNACIONAL COMO ANTECEDENTES HISTÓRICOS DOS PROJETOS DE "PAZ PERPÉTUA"}

É indubitável que a evolução histórica do Direito Internacional Público esteja intrinsecamente ligada à sua fundamentação teórica, às fontes e ao seu desenvolvimento no curso do tempo, sempre almejando, sobretudo, um estado de paz e harmonia entre as comunidades humanas, fossem organizadas em torno de clãs, nações ou, mais recentemente, em Estados institucionalizados ${ }^{16}$.

Já na antiguidade, era possível encontrar não somente um direito internacional consuetudinário, mas também, convencional, erigido por tratados internacionais, do que são provas: a) o tratado empreendido pelo rei Eannatum, datado de aproximadamente 3100, a.C., regulamentando as fronteiras do reino de Lagash com o reino vizinho de Umma (cidade-estado da Mesopotâmia), inclusive com a designação de um árbitro para dirimir eventuais conflitos (o rei Misilim, de Hish); b) o tratado estabelecido entre Ramsés II, faraó egípcio, e Hattisuli, rei dos Hititas, em matéria de extradição (tal como entendido o instituto à época), celebrado em 1820 a.C.; c) o livro chinês I King, elaborado cerca de 2500 a.C., contendo uma ampla narração de costumes considerados obrigatórios na relação entre dinastias da época; d) o Talmud babilônico; e) o Código de Manu ${ }^{17}$, do século II a.C., ambos representando codificações do Direito vigente à época, inclusive internacional ${ }^{18}$.

\footnotetext{
16“ A estruturacão do direito internacional como disciplina autônoma das ciências jurídicas foi devida, principalmente, à transferência do debate da guerra justa (guerra legítima) e a que não o era, baseada em consideracões filosóficas e ideológicas que, no nível do direito concebido como regime jurídico de relacões internacionais nesta situacão (guerra legal). No decurso de toda a história da humanidade é notável o desenvolvimento de regras que, apesar das diferenças fundamentais entre os conceitos ideológicos de tipo político, moral, cultural e socio-econômico que separavam diferentes civilizações, tinham um conteúdo muito semelhante no tocante ao comportamento das situações bélicas." SWINARSKI, Christophe. Direito internacional humanitário: como sistema de proteção internacional da pessoa humana (principais noções e institutos). São Paulo: Ed. Revista dos Tribunais; USP/NEV, 1990. p. 19-20.

17،Por exemplo, no Código de Manu, escrito em 200 a.C., encontram-se regras relacionadas a comportamento em combate. O Código declarou que armas farpadas ou envenenadas eram proibidas, que soldados feridos deveriam ser tratados e que combatentes que se rendiam deveriam ser poupados."
} 
Logo, este estudo vestibular tem por objetivo trazer de forma sintética o desenvolvimento do Direito Internacional Público como disciplina, na sua gênese, por meio de uma narrativa contextualizada de alguns fatos históricos e sobremaneira pela análise das contribuições teóricas e filosóficas dos chamados "precursores do direito internacional"19.

No final da Idade Média, com o crescimento dos Estados nacionais, surge o Direito Internacional moderno, reconhecendo-se como seus precursores juristas e estudiosos dos séculos XVI e XVII, todos europeus - e quase todos católicos, com alguns protestantes -, que tentaram articular normas de conduta ligadas ao Estado, por vezes introduzindo nele noções já bem estabelecidas na doutrina religiosa que praticavam, como o polêmico conceito de "guerra justa"20.

Importante noticiar, acerca dos chamados temas universais do direito internacional desde a mais remota Antiguidade, que Paulo Borba Casella aponta a presença de quatro grandes áreas que permeiam de forma destacada a evolução da disciplina: a guerra e a regulação das relações hostis (jus ad bellum e jus in bello); a diplomacia e as missões especiais, para fins de negociação; as transações, com destaque para os tratados; e a cooperação, lato sensu, extradição de criminosos, obras de interesse comum, $v . g .{ }^{21}$.

Nesse sentido, cumpre salientar que a história do direito internacional deve ser concebida como a de um fenômeno social específico, e que, apesar de estar estreitamente ligada à história geral, os períodos de ambas não coincidem necessariamente ${ }^{22}$.

BOUVIER, Antoine A. Direito internacional humanitário e direito dos conflitos armados. Williamsburg (EUA): Instituto para Treinamento em Operações de Paz, 2011. p. 4.

${ }^{18}$ ARIOSI, Mariângela. Conflitos entre tratados Internacionais e Leis internas: o judiciário brasileiro e a nova ordem internacional. Rio de Janeiro: Renovar, 2000. p. 44-45.

19، A história do Direito da Guerra determina a trajetória do próprio Direito Internacional Público, condicionando de maneira decisiva a elaboração de todo conjunto de normas deste último. $\underline{O}$ s próceres do Direito Internacional, mencionando só a Hugo Grócio, Francisco de Vitória ou Albérico Gentile, consideravam todos que as normas das relações internacionais deveriam se organizar ao redor do problema central da legalidade da guerra." SWINARSKI, Christophe. op. cit., p. 19.

${ }^{20}$ DINSTEIN, Yoram. Guerra, agressão e legítima defesa. 3. ed. Barueri: Manole, 2004. p. 92.

${ }^{21}$ CASELlA, Paulo Borba. Direito internacional no Tempo Antigo. São Paulo: Atlas, 2012. p. 464.

${ }^{22}$ DINH, Nguyen Quoc; DAILLIER, Patrick; PELLET, Alain. Direito internacional público. Tradução: Vítor Marques Coelho. 2. ed. Lisboa: Calouste Gulbenkian, 2003. p. 43. 
Tendo em vista o pressuposto de que todo estudo há de ser iniciado pela definição de seu objeto, faz-se necessário antes de adentrar propriamente em tais contribuições teóricas, situar e definir o Direito Internacional Público.

Em um primeiro momento, para tal definição, será adotado o que chamamos de acepção contemporânea do termo, ou seja, o conceito mais atual da doutrina, para que de forma indutiva e gradativa, possa-se notar a evolução do mesmo ao longo do trabalho, por meio das definições de cada período estudado ou de determinada proposta doutrinária ${ }^{23}$.

Comumente a doutrina clássica aponta a divisão entre direito interno e direito internacional, apoiando-se em um corte metodológico e didático, no intuito de melhor organizar o estudo da Ciência do Direito de forma sistemática.

A este respeito, temos que o chamado direito interno é aquele que rege as relações jurídicas no interior do sistema jurídico nacional ${ }^{24} \mathrm{e}$ em contrapartida, o direito internacional, em sua concepção atual, seria o conjunto de regras ou princípios destinados a reger os direitos e deveres internacionais tanto dos Estados e de certos organismos interestatais, quanto dos indivíduos ${ }^{25}$.

É possível constatar que a definição supra é bastante abrangente, vez que por muito tempo prevaleceu na doutrina a visão tradicional de que o Direito Internacional Público seria o conjunto de regras e princípios reguladores das relações entre os Estados Nacionais, estes seu sujeitos originários, como se verifica no intitulado direito internacional clássico.

\footnotetext{
${ }^{23}$ “A expressão de Direito Internacional Público é relativamente recente e não foi aceita de modo pacífico pelos doutrinadores. (...) A colocação do adjetivo "Público" desenvolveu-se nos países de lingua latina, a fim de distinguir do Direito Internacional Privado. Ao acrescentar o adjetivo "público" à expressão DI vem do século XVIII, mas só foi consagrada em meados do século XIX. Tal fenômeno não ocorre nos países de língua anglo-saxã: na Inglaterra e EUA usa-se "International Law" para DI Público e "Conflicts of Law" para o DI Privado, e na Alemanha, "Volkerrecht" (Direito das Gentes) para o DI Público e "Privat Internationales Recht" para o DI Privado. A denominação de Direito Internacional Público encontrou acolhida na maioria das línguas latinas: Droit International Public, Diritto Internazionale Publico, Derecho Internacional Publico e Direito Interrnacional Público." MELLO, Celso Duvivier de Albuquerque. Curso de direito internacional público. 13. ed. Rio de Janeiro: Renovar, 2001. p. 69.

${ }^{24}$ ACCIOLY, Hildebrando; SILVA, Geraldo Eulálio do Nascimento e; CASELLA, Paulo Borba. op. cit., p. 9.

${ }^{25}$ ACCIOLY, Hildebrando. Tratado de direito internacional público. 3. ed. São Paulo: Quartier Latin, 2009. v. 1, p. 27.
} 
Sabe-se, conforme bem ponderou Hans Kelsen em seu "Principles of International Law" (1952), que "qualquer tentativa de definir um conceito deve proceder de determinado uso linguístico, do sentido corriqueiro da palavra pela qual pretendemos designar o respectivo conceito". ${ }^{26}$

Com efeito, temos que a construção da linguagem é uma das questões cruciais para o direito, e no caso específico do direito internacional, torna-se mais complexa em razão da multiplicidade de atores e idiomas.

A expressão "Direito Internacional Público" hoje consagrada como a nomenclatura da disciplina em apreço, é relativamente recente. Tal designação é oriunda de international law, que fora utilizada pela primeira vez por Jeremy Bentham (17481832), jurista inglês, em 1780 no livro "Introduction to the Principles of Morals and Legislation”, em oposição aos termos national Law ou municipal law. ${ }^{27}$

Em verdade, a intenção do autor era dar uma denominação mais precisa para a expressão "Law of nations", haja vista que, ao contrário da língua inglesa, onde nations

\footnotetext{
${ }^{26}$ KELSEN, Hans. Princípios do direito internacional. Tradução: Ulrich Dressel e Gilmar Antonio Bedin. Ijuí: Unijuí, 2010. p. 29.

${ }^{27}$ BENTHAM, Jeremy. An introduction to the principles of morals and legislation. New York: Dover, 2007. p. 326-328. Chapter XVII - Of the Limits of the penal branch of Jurisprudence. $\$ 2$. Jurisprudence, it branches. Jurisprudence, local-universal-internal and internacional.
}

(...) $\underline{X X V}$. In the second place, with regard to the political quality of the persons whose conduct is the object of law. These may, on any given occasion, be considered either as members of the same state, or as members of different states: in the fist case, the law may be referred to the head of internal, in the second case, to that of international jurisprudence.

Now as to any transactions which may take place between individuals who are subjects of different states, these are regulated by internal laws, and decided upon by the internaltribunals, of the one or the other of states: the case is the same where the sovereign of the one has any immediate transactions with a private member of the other: the sovereign reducing himself, pro re natâ, to the condition of a private person, as often as he submits his cause to either tribunal; whether by claiming a benefit, or defending himself against a burthen. There remain then the mutual transactions between sovereigns, as such, for the subject of that branch of jurisprudence which may be properly and exclusively termed international.

With what degree of propriety rules for the conduct of persons of this description can come under the appellation of laws, is a question that the must rest till the nature of the thing called a law shall have been more particulary unfolded.

It is evident enough, that international jurisprudence may, as well as internal, be censorial as well as expository, unauthoritative as well as authoritative. - 326 e 327.

$\underline{X X V I . I n t e r n a l}$ jurisprudence, again, may either concernall the members of a state indiscriminately, or such of them only as are connected in the way of residence, or otherwise, with a particular district. Jurisprudence is accordingly sometimes distinguished into national and provincial. But as the epithet provincialis hardly applicable to the districts so small as many of those which have laws of their own are wont to be, such as towns, parishes, and manors; the term local (where universal jurisprudence is plainly out of question) or the term particular, though this latter is not very characteristic, might either be more commodious. -327 e 328 . 
conserva a polissemia de ter o significado de nação, estado ou país; em francês e demais línguas latinas o mesmo não ocorre, propiciando uma incongruência semântica.

Atente-se que Bentham buscou enfatizar o uso do prefixo “inter”, tal qual Francisco de Vitória o fizera no século XVI, na clara tentativa de assinalar a aplicação do direito "entre" os sujeitos.

Cumpre ainda destacar, que foi somente na tradução francesa de "Introduction to the Principles of Morals and Legislation", feita por Étienne Dumont e publicada na Suíça em 1802, que o qualificativo "público" foi acrescentado ao termo originário "direito internacional", no firme propósito de distinguir a disciplina do conflict of laws, assim conhecido o chamado "direito internacional privado", nos países de língua anglo-saxã.

Essa distinção binária entre direito internacional público e direito internacional privado, encontra plena aceitação nos programas de ensino, do que são exemplos os prestigiosos cursos ministrados anualmente pela Academia de Direito Internacional da $\mathrm{Haia}^{28}$, sendo que o último, de forma peremptória, é acompanhado do qualificativo privado, ao passo que a expressão "direito internacional", sem nenhum qualificativo refere-se ao direito internacional público, dada a origem inglesa do termo, já devidamente elucidada.

Compartilhamos desse juízo, e apenas no intuito de não tornar o texto muito "poluído", optamos por utilizar a expressão direito internacional em detrimento de direito internacional público. Portanto, toda vez que se fizer referência ao direito internacional, neste trabalho, referimo-nos ao ramo público da disciplina.

\footnotetext{
${ }^{28}$ Desde sua criação em 1923, custeada pela Carnegie Foundation, de Washington, a Academia de Direito Internacional da Haia ocupa instalações anexas ao Palácio da Paz, imediatamente ao lado de duas das mais importantes instituições judiciárias internacionais: a Corte Internacional de Justiça e a Corte Permanente de Arbitragem Internacional. É uma centro de pesquisa e ensino de Direito Internacional Público e Privado, que visa ao aperfeiçoamento e desenvolvimento de estudos científicos avançados, dos aspectos jurídicos das relações internacionais. Esta missão, alinhada por seus fundadores com a corrente de pensamento "paz através do Direito", mantêm-se relevante até hoje. Para cumprir com sua missão, a Academia logrou sucesso tanto em preservar as tradições oriundas das Conferências de Paz da Haia, de 1899 e 1907, quanto em adaptar-se às mais recentes necessidades de um mundo que passa por profundas modificações. THE HAGUE ACADEMY OF INTERNATIONAL LAW. History. Disponível em: $<$ http://www.hagueacademy.nl/?history>. Acesso em: 13 nov. 2012.
} 
Inquestionável que nos dias atuais a denominação direito internacional integrou-se de forma sedimentada ao uso corrente, fazendo com que possíveis tentativas de novas construções terminológicas não logrem êxito.

Vale lembrar, contudo, que até o aparecimento do livro de Bentham, outra denominação obtinha a predileção da doutrina: "Direito das Gentes", ou Law of nations ${ }^{29}$ ou ainda Völkerrecht.

O "Direito das Gentes" consistia, prima facie, em uma tradução literal do jus gentium $^{30}$ romano, porém, em respeito ao rigor terminológico ora adotado, não devem ser confundidos, sobretudo porque originalmente tinham significados distintos, e assim eram utilizados pelos precursores da disciplina, como veremos adiante.

Acerca do jus gentium romano, preciosa lição apresenta Guido Fernando Silva Soares:

\begin{abstract}
"Tratava-se de um corpo de normas que regulava, no interior do Império Romano, os direitos dos indivíduos (como a personalidade, as capacidades), seus relacionamentos interpessoais (como família e as sucessões, os contratos e os efeitos dos atos lícitos e ilícitos), alguns aspectos de direito criminal e, sobretudo, as normas sobre a atividade de produzir a norma jurídica (a jurisdictio, devendo destacar-se a existência e a atuação de um magistrado especializado em questões que envolvessem um estrangeiro: $o$ praetor peregrini).(...) jus gentium espraiou-se pelos povos conquistados, que bem o aceitaram, por suas qualidades de maior precisão e perfeição, em relação aos direitos costumeiros locais e tradicionais, ou bem tiveram que aceitá-lo, na condição de povos subjugados(...)". ${ }^{31}$
\end{abstract}

Todavia, ao final do século XVII a denominação jus gentium delineou-se no sentido de termo técnico, designando o conjunto de normas para regular as relações entre estados independentes ${ }^{32}$.

\footnotetext{
${ }^{29}$ Termo já devidamente explicado.

30 "Jus gentium (of Roman law) had it's origins in private law, having subsequently entered also the realm of the conceptual universe of the law of nations. It originally consisted of common principles governing legal relations in general. Gradually the concept of jus gentium was enlarged, so as to encompass what came to be know as the general principles of law(...)”. TRINDADE, Antônio Augusto Cançado. International law for humankind: towards a new jus gentium. Leiden: Martinus Nijhoff, 2010. p. 9.

${ }^{31}$ SOARES, Guido Fernando Silva. Curso de direito internacional público. São Paulo: Atlas, 2002. p. 24.

${ }^{32}$ CASELLA, Paulo Borba. Direito internacional no tempo antigo, cit., p. 442.
} 
Cumpre dizer que a expressão jus gentium foi utilizada por Samuel Pufendorf (século XVII), no sentido de direito natural, em seus "Elementorum jurisprudentiae universalis" e também por Isidoro de Sevilha em "Etimologias ${ }^{33, "(633), ~ q u e ~ a f i r m a v a: ~ “ ~} A$ lei natural é comum a todas as nações". ${ }^{34}$

Sob este prisma, nos dizeres do Professor Vicente Marotta Rangel, temos que: "Durante muitos séculos o termo jus gentium foi empregado ao lado do direito natural (jus naturale), para designar um direito comum a todos os homens, "quod naturalis ratio inter omnes homines constituit ${ }^{35}$ ".

Posteriormente, a partir da visão cristã advinda da fase final do Império Romano, foi-se elaborando as bases do que passaria a ser o "Direito das Gentes", destacando-se nesse contexto a escolástica de Santo Agostinho e São Tomás de Aquino ${ }^{36}$.

Entendemos que a expressão "Direito das Gentes" evoca um sentido muito mais amplo do que o trazido pelo jus gentium, e pela própria designação "direito internacional", à medida que revela a noção de um direito comum a todas "as gentes", independente da necessidade de uma coletividade organizada (Estados), recaindo na tônica contemporânea dos indivíduos como novos sujeitos do Direito Internacional ${ }^{37}$.

Essa abordagem é dada no conceito enunciado por Montesquieu em "Do Espírito das Leis" (1748), acerca do Direito das Gentes: "Considerados como habitantes de um planeta tão grande, a ponto de ser necessário que nele existam

\footnotetext{
33 “(...) espécie de enciclopédia, na qual resume o conjunto dos conhecimentos de seu tempo, compulsando extensamente fontes antigas. Estas serviram, ao lado de AGOSTINHO, como uma das bases para a atividade intelectual, no Ocidente, durante cerca de mil anos. (...)”, in: CASELLA, Paulo Borba. Direito internacional no tempo antigo, cit., p. 460.

${ }^{34}$ MORRIS, Clarence (Org). Os grandes filósofos do direito. Tradução: Reinaldo Guarany. São Paulo: Martins Fontes, 2002. p. 61.

${ }^{35}$ RANGEL, Vicente Marotta. Prefácio. In: VATTEL, Emmerich. O direito das gentes ou princípios da lei natural aplicados à condução e aos negócios das nações e dos governantes. Tradução: Ciro Mioranza. Ijuí: Unijui, 2008. p. XLVIII.

36 “(...) Thomas Aquinas (1225-1274) did consider the concept of jus gentium in his Summa Theologica. In his view, jus gentium did not need the authority of the legislator, as it was apprehended by natural reason itself (being thus more perfect than positive law), disclosing awareness of the temporal dimension and being endowed with a universal validity. (...) The preceptsof jus gentium, in Aquina's view, were universally valid and fulfilled natural necessities of human life; they reflected a kind of human self-understanding (...)”. TRINDADE, Antônio Augusto Cançado. op. cit., p. 12.

${ }^{37}$ Prova desta maior abrangência é a retomada da expressão por George Scelle no seu "Précis de Droitdes Gens" (1932-1934).
} 
diferentes povos, existem leis nas relações que esses povos mantêm uns para com os outros: o Direito das Gentes. 38

Ressalte-se, que a utilização de uma ou outra definição (jus gentium, "Direito das Gentes”, ou direito internacional), suscita interferência recíproca entre os conceitos. Tal interferência é bastante comum, principalmente com a utilização de "direito das gentes" no sentido de designar o direito internacional clássico, como poderá ser constatado em alguns teóricos do DI.

No século XVI, a fórmula latina jus inter gentes foi adotada por Francisco de Vitória, ao substituir na célebre definição de Gaio nas Institutas, "quod vero naturalis ratio inter omnes homines constituit...vocaturque jus gentium" o vocábulo latino homines por gentes ${ }^{39}$.

Novamente, em 1650 a expressão "inter gentes" foi utilizada pelo inglês Richard Zouch, em conjunto com "jus fetiale”, em sua obra "Juris et judici fetiales, sive juris inter gentes et quaestionorum de eodemexplicatio”(Exposição do Direito e Processo dos feciais, ou o Direito entre as nações). Sendo que o "jus fetiale” era o conjunto de normas utilizadas, em Roma, nas relações com as nações estrangeiras, possuidoras de um caráter jurídico e ao mesmo tempo nitidamente religioso ${ }^{40}$.

Ainda no tocante à questão terminológica, outras nomenclaturas foram propostas para a disciplina, todavia nenhuma obteve sucesso na doutrina: "droit entre lesgens” (D’Aguesseau); “Droit Public Internacional” (A. Mérignhac); "Droit Public de l'Europe" (Mably); "Direito Público Externo" (Hegel); "Direito Interpúblico"

\footnotetext{
${ }^{38}$ MONTESQUIEU, Charles-Louis de Secondat. Do espírito das Leis. Tradução: Jean Melville. São Paulo: Martin Claret, 2002. p. 21. (Livro Primeiro: Das leis em geral. Capítulo I: Das Leis quanto às suas relações para com os diversos seres).

39 “(...) when the dichotomy jus gentium/jus inter gentes emerged, the international legal order had not yet displayed a strictly inter-State dimension. The roots of the distinction between jus gentium and jus inter gentes can be found as early as in the wrintings of the founding fathers of the discipline in the XVIth and XVIIth centuries, but by then two notions referred to an emerging law of nations comprising also people and individuals. (...) The historical transformation of jus gentium into jus inter gentes - this latter primarily concerned with ensuring the co-existence and co-ordination of its subjects - was also prompted by the absence or lack of an international legislature and an international judiciary, wich only in recent decades began to take shape (...)”. TRINDADE, Antônio Augusto Cançado. op. cit., p. 14.

${ }^{40}$ MELLO, Celso Duvivier de Albuquerque. op. cit., v. 1, p. 155.
} 
(Retortillo); "Direito Social Universal” (Zeballos); "jus interpotestates”(Taube) e por fim "Staatenrech" ou "jus publicum civitatum" (Kant). ${ }^{41}$

Julgamos de bom alvitre, vermos a definição proposta por Kant, vez que mais adiante será dedicado ao filósofo um estudo minucioso acerca de sua de sua teoria de paz na modernidade.

Desse modo, temos em sua obra "Doutrina do Direito" na qual o autor tratou de enunciar o próprio conceito de doutrina e direito, o que segue:

“(...) O direito das cidades ou dos Estados na relação entre si, direito que se chama bastante impropriamente de direito dos povos ou de gentese que deveria, na verdade, se chamar direito público dos Estados (jus publicum civitatum), é agora o que temos que examinar sob o nome de direito de gentes"

Igualmente, dignas de nota são as expressões suscitadas por Philip Caryl Jessup e John Rawls. O primeiro propôs transnational law, ou seja, "direito transnacional" (1956), com o objetivo de abranger todos os princípios que regem os fatos que ultrapassem as fronteiras estatais. Em adição, sustentou que a designação comporta em si mesma tanto o direito público quanto o privado, constituindo um novo ramo da Ciência do Direito ${ }^{43}$.

Em 1999, John Rawls publica “O Direito dos Povos”, e logo na introdução explicita que pretende com esta designação referir-se a uma concepção política particular do direito e da justiça, com aplicação aos princípios e normas do Direito e da prática internacional, asseverando ainda, que o "Direito dos Povos", deriva do jus gentium tradicional e que a expressão latina “jus gentium intra”, refere-se aos direitos que todos os povos possuem em comum ${ }^{44}$.

\footnotetext{
${ }^{41}$ MELLO, Celso Duvivier de Albuquerque. op. cit., v. 1, p. 69.

${ }^{42}$ KANT, Immanuel. Doutrina do direito. Tradução: Edson Bini. 2. ed. São Paulo: Ícone, 1993. Segunda Parte: Seção II: Direito de Gentes. p. 191.

${ }^{43}$ MELLO, Celso Duvivier de Albuquerque. op. cit., v. 1, p. 70.

${ }^{44}$ RAWLS, John. O direito dos povos. Tradução: Luís Carlos Borges. 2. ed. São Paulo: Martins Fontes, 2004. p. 3.
} 
Superada a questão terminológica, passaremos na sequência, ao exame da tradição no pensamento ocidental de algumas contribuições teóricas que serviram de arcabouço jurídico para o fomento do aparecimento dos chamados "projetos de paz perpétua" e para o desenvolvimento do direito internacional.

Contudo, convém explicitar que em um estudo sobre a tradição dos projetos de paz perpétua no pensamento ocidental, duas questões devem ser abordadas inicialmente: o enfoque cronológico e o eixo territorial.

Sob essa perspectiva, e em consonância com o aludido objetivo deste estudo preambular, far-se-á um breve relato sobre a construção teórica do direito internacional, cujo enfoque recairá de forma reflexa na Idade Moderna e no plano europeu, por meio das contribuições doutrinárias dos precursores e demais autores selecionados neste capítulo.

Isto ocorre porque, durante um longo período, a história do direito internacional confundiu-se em larga escala com a história europeia ${ }^{45}$ : a paz de Vestfália $^{46}$ (1648) deu origem, na Europa, ao Estado Moderno e, em consequência, foi também o vertedouro das doutrinas basilares da disciplina sob a ótica de ciência jurídica contemporânea.

Contudo, acreditamos que o direito internacional não é uma criação moderna e principalmente por constituir-se um fenômeno social deve ele ser considerado à luz de um todo evolutivo e não de maneira compartimentada.

Apresentados esses apontamentos iniciais, explanaremos acerca de alguns institutos e correntes filosóficas que permearam o direito internacional nos primeiros períodos da história da humanidade e as contribuições que esses trouxeram para a elaboração de conceitos, que na atualidade, são intrínsecos à própria existência da disciplina.

\footnotetext{
${ }^{45}$ DINH, Nguyen Quoc; DAILLIER, Patrick; PELLET, Alain. op. cit., p. 39.

46 “(...) Vestfália (1648) pode ser escolhido como referência e ponto fundamental de instauração do que viria a ser sistema "moderno" de equilíbrio de poder entre as potências da época na Europa, ao mesmo tempo em que se pode mostrar como este marco se inscreve em contexto de continuidade histórica, $e$ perde sentido se for destacado e se achar desvinculado do tempo e do contexto no qual foi encetado. $O$ fracionamento político obrigou à institucionalização das regras de convivência entre as unidades (...)”., in: CASELLA, Paulo Borba. Direito internacional no tempo antigo, cit., 2012.
} 
No período Antigo, analisaremos dois expoentes no tocante ao grau de sofisticação dos institutos jurídicos internacionais cuja repercussão das análises filosóficas e políticas encontram paralelos nos demais períodos históricos, motivo pelo qual recebem a denominação de "Antiguidade Clássica”: Grécia e Roma ${ }^{47}$.

Nesse sentido, a Grécia representa um dado excepcional na Antiguidade para o direito internacional. Esta excepcionalidade reside tanto nas análises filosóficas, científicas e políticas legadas à humanidade quanto ao conjunto de inter-relações construídas dentro do mundo helenístico ${ }^{48}$.

Especial destaque há de ser dado à filosofia grega, ante a contribuição ímpar do conceito de direito natural elaborado pela "escola estóica" ${ }^{49}$ de Zenão de Cítio, no século III a. C., que de forma salutar propagava um conjunto de normas de pertinência universal, constituindo o primeiro momento do movimento "jusnaturalista", para o qual a natureza é a fonte da lei ${ }^{50}$.

\begin{abstract}
"Eram normas racionais e lógicas; e, como os preceitos da "lei da natureza" estavam arraigados na inteligência humana, seguia-se daí que tais normas não poderiam ser restritas a uma nacão ou a um grupo determinado, mas aplicavam-se ao mundo inteiro. Esse elemento de universalidade é fundamental para as doutrinas modernas do direito internacional, e a elevação estoica da faculdade humana de dedução lógica ao pináculo supremo da descoberta do direito natural prefigura as filosofias racionalistas do Ocidente. Além de ser um conceito fundamental da teoria do direito, o direito natural é essencial para a compreensão do direito internacional, e é também um precursor indispensável do atual interesse pelos direitos humanos ${ }^{, 51}$.
\end{abstract}

\footnotetext{
${ }^{47}$ Fustel de Coulanges, em sua obra "a Cidade Antiga", agrupou o estudo dessas duas cidades, sob o fundamento de que se tratava de dois povos oriundos de dois ramos de uma mesma raça, e que guardadas as devidas proporções possuíram também as mesmas instituições e os mesmos princípios de governo. Este estudo "agrupado", proposto pelo autor, mostra-se útil na medida em que percebemos as influências recíprocas no desenvolvimento das questões afetas ao estrangeiro, na guerra e paz, nas civilizações clássicas. FUSTEL DE COULANGES, Numa Denis. A cidade antiga: estudo sobre o culto, o direito e as instituições da Grécia e de Roma. Tradução: Roberto Leal Ferreira. São Paulo: Martin Claret, 2009.

${ }^{48}$ SHAW, Malcom N. Direito internacional. São Paulo: Martins Fontes, 2010. p. 14.

${ }^{49}$ Acerca da ética estóica: “(...) A ética estóica caminha no sentido de postular a independência do homem com relação a tudo o que o cerca, mas, ao mesmo tempo, no sentido de afirmar seu profundo atrelamento com causas e regularidades universais. A preocupação com o conceito de dever (kathékon) irrompe com uma série de consequências histórico-filosóficas que haveriam de marcar nuances anteriormente existentes. Razão, dever, felicidade, sabedoria e autonomia relacionam-se com proximidade (...), in: BITTAR, Eduardo C. B.; ALMEIDA, Guilherme Assis de. Curso de filosofia do direito. 8. ed. São Paulo: Atlas, 2010. p. 173.

${ }^{50} \mathrm{O}$ segundo momento da chamada corrente jusnaturalista será visto adiante na visão de Hugo Grócio.

${ }^{51}$ SHAW, Malcom N. op. cit., p. 15.
} 
A despeito de referida contribuição e em clara contradição, sem dúvida havia um relacionamento de profunda hostilidade entre os gregos e outros povos, então denominados bárbaros ${ }^{52}$.

Essa constante hostilidade propiciou um "direito da guerra" extremamente duro para com o "inimigo". Na Grécia antiga o estado de paz associava-se necessariamente à existência de um pacto prévio com prazo determinado. Em Atenas, o juiz dos estrangeiros recebia o nome de polemarca, sendo encarregado dos assuntos bélicos e de todas as relações com os inimigos, assim denominados os estrangeiros.

Com o decorrer do tempo, foram sendo estabelecidas regras no sentido de atenuar o rigor da guerra ou pelo menos discipliná-la. Ótimo exemplo é o programa de humanização da guerra entre as cidades gregas, apresentada por Platão no livro V de sua obra "A República", conforme demonstra o pequeno trecho do diálogo entre Polemarco e Sócrates:

471 a-e(...) - "Sendo Gregos, não devastarão a Grécia, nem incendiarão as casas, nem proclamarão seus inimigos todos os habitantes de cada cidade, homens, mulheres e crianças, mas aos poucos adversários causadores da discórdia. E, por todos estes motivos, nem quererão devastar o território deles, pensando que a maior parte dos habitantes são seus amigos, nem arrasar as habitações, e manterão a sua dissensão até os culpados serem forçados, pelos inocentes que sofrem, a expiar a sua culpa.

- Eu, pela minha parte, concordo que é assim que os nossos cidadãos devem comportar-se com os seus adversários. Com os bárbaros, devem proceder como atualmente os Helenos uns contra os outros $(\ldots)^{53 \%}$.

Imperioso notar que o mundo grego conheceu e praticou diversos institutos do direito internacional tais como conhecemos hoje, dentre os quais podemos citar: os

\footnotetext{
52““(...) Em todos os periodos da civilização grega, imperava o entendimento de que a guerra seria o estado normal das relações entre os povos, entrecortadas por breves periodos de paz, o que explica em parte, a educacão da juventude, bastante centrada nos valores militares (...)”, in: SOARES, Guido Fernando Silva. op. cit., p. 23.

${ }^{53}$ PLATÃO. A República. Tradução: Pietro Nassetti. São Paulo: Martin Claret, 2003. Livro V, p. 167-168.
} 
tratados, a arbitragem como meio de solução de litígios, o princípio da necessidade da declaração da guerra, o direito de asilo e a inviolabilidade dos embaixadores ${ }^{54}$.

Em especial, quanto à arbitragem encontrou o instituto um meio social favorável à sua prática. Contavam os gregos com a arbitragem obrigatória e a facultativa, em exata consonância com os modelos mais atuais de legislação arbitral.

Impossível deixar de enxergar que os romanos distinguiram-se dos demais povos da Antiguidade. Muito dessa distinção é oriunda da capacidade extraordinária do mundo romano de sistematizar o seu Direito em graus específicos de complexidade, muito superior às demais civilizações da época. A contribuição romana apresenta uma acentuada particularidade: realizou-se principalmente mediante instituições do seu Direito interno ${ }^{55}$.

Nesse sentido, podemos citar os "sacerdotes feciais" que desde os tempos da monarquia, deveriam ser obrigatoriamente consultados antes de se iniciar uma guerra ou se concluir a paz. A existência dessas consultas e dos complicados procedimentos para a declaração da guerra encontra razão no propósito de congregar a opinião pública, colimando os esforços dos cidadãos ante a latência da guerra.

O instituto do jus fetiale existiu na antiga Roma, desde os dias dos reis até o final da era republicana. Os fetiali eram corporações de sacerdotes encarregados de uma série de obrigações, algumas delas referentes ao início da guerra. Via de regra, os detentores do poder político em Roma não podiam declarar guerra sem a aprovação prévia e explícita, de natureza ritualística, exarada pelos fetiali ${ }^{56}$.

Fácil inferir que o jus fetiale era originalmente uma norma interna romana, de caráter consuetudinário, que ao mesmo tempo continha inegavelmente elementos internacionais.

(...) O direito fecial é de natureza religiosa. Para compreendermos porque se destina a reger as relações internacionais, devemos lembrar que Roma as coloca sob o signo da religião a fim de merecer a proteção divina nas suas relações com os estrangeiros. A aplicação e a

\footnotetext{
${ }^{54}$ ACCIOLY, Hildebrando. Tratado de direito internacional público, cit., v. 1, p. 85.

${ }^{55}$ TRUYOL Y SERRA, Antonio. História do direito internacional público. Tradução: Henrique Barrilaro Ruas. Lisboa: Instituto Superior de Novas Profissões, 1996. p. 28. (Coleção Estudos Gerais).

${ }^{56}$ DINSTEIN, Yoram. op. cit., p. 87-88.
} 
interpretação deste direito estão mesmo confiadas a religiosos, sacerdotes feciais, que são, ao mesmo tempo, verdadeiros embaixadores romanos. Gozam nesta qualidade de inviolabilidade. Atentar contra as suas pessoas é ofender os deuses. O direito fecial também estabeleceu a distinção entre guerra justa e guerra injusta $(\ldots)^{57}$.

Entre o fim da República e o princípio do Império, oriundo da expansão, e por consequência, do contato com os outros povos e principalmente do grande número de estrangeiros em Roma, o jus gentium veio preencher uma lacuna jurídica existente para os "não-romanos", vez que para os romanos havia o jus civile.

O jus gentium, mesmo pertencente ao direito interno romano, diferenciou-se exponencialmente do formal jus civile. Sem dúvidas, essa diferenciação é oriunda da atuação do praetor peregrinus (magistrado dos estrangeiros), pois esse possuía uma larga margem de liberdade quando da aplicação do jus gentium, em função da flexibilidade exigida no âmbito de aplicação do mesmo em detrimento do rigoroso formalismo do jus civile.

Desde o período antigo, era unicamente o fato de o indivíduo pertencer ou não a uma determinada gens romana, que o possibilitava ao reconhecimento da cidadania. O Direito Romano clássico previa que aquele que pertencesse a um determinado clã romano, tinha a possibilidade de reconhecimento da sua cidadania. Isto porque gens e familiae eram consideradas organismos anteriores ao Estado. O pertencer a uma gens também era pressuposto da liberdade, elemento essencial à concepção de cidadania do pensamento romano ${ }^{58}$.

Todo homem livre era um cidadão da cidade que o originou ${ }^{59}$. Eram excluídos do direito à cidadania, sofrendo limitações à capacidade jurídica, as mulheres, as crianças, os escravos, os apátridas e os estrangeiros, embora, em relação aos últimos,

\footnotetext{
${ }^{57}$ DINH, Nguyen Quoc; DAILLIER, Patrick; PELLET, Alain. op. cit., p. 48.

${ }^{58}$ DAL RI JUNIOR, Arno. Evolução histórica e fundamentos político-jurídicos da cidadania. In: OLIVEIRA, Odete Maria de (Orgs.). Cidadania e nacionalidade: efeitos, perspectivas, nacionais, regionais, globais. 2. ed. Ijuí (RS): Ed. Ijuí, 2003. p. 30.

59“"A utilização deste instituto vem apresentada com muita clareza pela história do cidadão romano Saulo de Tarso, mais conhecido no ocidente como São Paulo. Em alguns versículos do livro Atos dos Apóstolos, Lucas conta como, em várias ocasiões, São Paulo conseguiu impor sua liberdade de cidadão romano, limitando, e às vezes, até impedindo, a ação das autoridades romanas que perseguem os cristãos. $\underline{\boldsymbol{O} \text { grito }}$ Civis Romanus Sum, tantas vezes utilizado por São Paulo, é a afirmacão desesperada de um direito perante a autoridade romana, materializado na forma de um forte sistema de garantias jurisdicionais $e$ de protecãa à pessoa." DAL RI JUNIOR, Arno. op. cit., p. 38.
} 
seja notório que Roma reconhecia a validade de ordens jurídicas estrangeiras, conforme ensinamento de Ulpiano ao reconhecer validade ao testamento deixado por estrangeiro (peregrinus), secundum leges suae civitatis.

Outro aspecto relevante a tratar é o do caráter da universalidade do jus gentium em Roma. Esse caráter universal deve-se muito à retomada do pensamento estóico grego por Marcus Tullius Cícero (106-43 a. C.) em sua clássica formulação de lei natural - "Lex est ratio summa, insita in natura, quae iubet quaefacienda sunt prohibet que contraria ${ }^{60 ",}$. -, posteriormente prolongada em uma teoria do próprio jus gentium, motivo pelo qual ambos foram durante muitos séculos empregados no mesmo sentido

Coube a Cícero a tarefa de descrever o Direito Romano de sua época. No entanto, ele o fez dentro de uma prospecção tipicamente filosófica, fincando suas raízes nos fundamentos naturais. A esse respeito:

\begin{abstract}
"Assim, para definir o Direito, o ponto de partida será aquela Lei suprema que pertence a todos os tempos e já estava em vigor quando não existia lei escrita, nem Estado constituído. (...) Buscarei a raiz do Direito na Natureza, que será nossa mestra e guia no curso desta discussão ${ }^{61}$.

\section{(...) Logo, devemos reconhecer que nosso universo é uma comunidade única, constituída pelos deuses e pelos homens ${ }^{, 62}$.}

Dentro dessa visão ciceroniana, pode-se compreender a relação dos romanos com a guerra, que em um primeiro momento foi exercida como resposta à ofensa praticada por outros povos, ou para defender, fortalecer ou recuperar províncias do Império. Assim sendo, não havia um espírito de agressão, ganância ou vaidade imperial ${ }^{63}$. Pois, para Cícero, a guerra só poderia ser justificada quando a paz não pudesse ser alcançada de outro modo.

\footnotetext{
${ }^{60}$ VAlENTE, Pe. Milton S. J. A ética estóica em Cícero. Caxias do Sul: Educs, 1984, p. 465 apud CÍCERO, Marcos Túlio. Tratado das Leis. Tradução: Marino Kury. Caxias do Sul: Educs, 2004.

${ }^{61}$ CÍCERO, Marcos Túlio. op. cit., p. 48-49.

${ }^{62}$ Id. Ibid., p. 50.

${ }^{63}$ CASELLA, Paulo Borba. Direito internacional no tempo antigo, cit., p. 325.
} 
Nota-se também, o desenvolvimento dos conceitos de guerra justa, cooperação e hospitalidade por meio dos tratados que poderiam ser de três espécies: de amizade (amicitia); de hospitalidade (hospitium) $e$ de aliança (foedus).

O amicitia conferia ao estrangeiro uma garantia de vida e inviolabilidade de bens, e em contrapartida ele se comprometia a não auxiliar os inimigos de Roma. Já o “hospitium" ou "hospitium publicus" tinha uma natureza mais ampla do que o tratado de amizade, pois estipulava de um modo geral a hospitalidade pública para com os estrangeiros e a recíproca tutela jurídica nas relações de direito privado ${ }^{64}$.

Os tratados de aliança, de seu turno, se dividiam em duas categorias. O foedus aequum era um tratado de aliança defensiva, que incluía deveres de assistência mútua, já o foedus iniquum impunha à outra parte obrigações unilaterais, como por exemplo, o dever de apoio à Roma em caso de ofensiva contra outra cidade ${ }^{65}$. Esta nomenclatura dos tratados romanos tem sua origem em parte no caráter inerente da religiosidade dos atos jurídicos romanos, pois o tratado, para ter validade, advinha necessariamente de um ato religioso.

"Assinar um tratado é uma expressão completamente moderna; os latinos diziam ferir um cabrito, icerehaedus ou foedus; o nome da vítima mais comumente empregada para isso permaneceu na língua usual para designar o ato inteiro" $"$.

Insta, ainda, dizer que os princípios jurídicos básicos como pacta sunt servanda, e a boa-fé tinham plena aplicação nos tratados celebrados pelos romanos.

Os romanos também contribuíram para a cristalização do conceito de "guerra justa", haja vista que a guerra (bellum justum) somente poderia ser declarada havendo justa causa (justa causa belli). ${ }^{67 .}$

Quanto à guerra justa, foi ela mencionada no "Res gestae divi Augusti" (1314 a. C.), aonde o então imperador Augusto, em seu $76^{\circ}$ ano de vida, mandou registrar em

\footnotetext{
${ }^{64}$ MELLO, Celso Duvivier de Albuquerque. op. cit., v. 1, p. 155-156.

${ }^{65}$ TRUYOL Y SERRA, Antonio. op. cit., p. 30.

${ }^{66}$ FUSTEL DE COULANGES, Numa Denis. A cidade antiga: estudo sobre o culto, o direito e as instituições da Grécia e de Roma, cit., p. 225.

${ }^{67}$ CASELLA, Paulo Borba. Direito internacional no tempo antigo, cit., p. 325.
} 
latim e grego o fato da consolidação do Império e a ampliação de suas fronteiras terem ocorrido "sem travar guerra injusta com qualquer tribo". ${ }^{6}$

Nesse contexto, pode-se inserir também a "pax romana", que era uma situação de relativa pacificação existente entre os povos subjugados pelo Império Romano, no sentido de existir uma communitas christiana ${ }^{69}$.

Por derradeiro, importante destacar que o cosmopolitismo é um dado marcante na civilização romana, manifestando-se na receptividade e na estreita relação da presença da cultura grega em Roma, em quase todas as suas nuances dentre as quais podemos destacar a filosofia, a poesia e o teatro.

O início da Idade Média é dado com o fim do Mar Mediterrâneo como "mare nostrum romano", e o deslocamento do eixo da vida histórica para o norte, o que ocasionou o fracionamento da unidade indissolúvel do Império Romano, levando à fragmentação e a instauração do feudalismo, modo de organização social e político que marca este período.

Toda e qualquer análise sobre a Idade Média do Ocidente deve ser realizada sob a ótica de uma herança cristã oriunda do último período do Império Romano, pois é justamente nessa perspectiva de continuidade de períodos históricos, e à luz da existência de uma única religião organizada e incorporada na figura da Igreja Católica, que poderemos encontrar a razão da existência de certos institutos jurídicos e correntes doutrinárias de cunho teológico $^{70}$ que contribuíram de forma ímpar para o contínuo desenvolvimento do direito internacional e também para a investigação da paz na modernidade.

\footnotetext{
${ }^{68}$ CASELLA, Paulo Borba. Direito internacional no tempo antigo, cit., p. 317.

${ }^{69 ، L a}$ pérdida de las virtudes cívicas que caracterizaran al pueblo romano a impulses del despotismo imperial; el abandono y la molicie que hubieron de caracterizarlo y lo llevaron a abandonar su defensa en mercenarios extranjeros, provocaron la destrucción del poderoso estado romano y la invasión por parte de los bárbaros y ocupación por parte de éstos, de los territorios que habían constituido su dominio. Con la desaparición del Imperio Romano de Occidente a manos de los bárbaros retornó la lucha entre pueblos." UGARTE, José Manuel. Los conceptos jurídicos e políticos de la seguridad y la defensa. Buenos Aires: Plus Ultra, 2003. p. 19.

70 “(...) O cristianismo enquanto tal não é uma filosofia. De fato, uma filosofia é constituída pela razão, ao passo que o cristianismo é uma religião revelada. (...) os temas da fé cristã foram realmente o plano de partida de uma reflexão filosófica original (...)", in: VERGEZ, André; HUISMAN, Denis. História dos filósofos ilustrada pelos textos. Tradução: Lélia de Almeida Gonzáles. 6. ed. Rio de Janeiro:Freitas Bastos, 1984. p. 92.
} 
Dessa forma, restou que a religião, ao lado do legado comum do Império Romano, constituíram fortes influências "unificantes" que se contrapunham de forma radical à estrutura atomizada existente. O imperium mundi romano transformou-se, paulatinamente, no imperium christianum ${ }^{71}$.

Assim sendo, temos que no ocidente, o Medievo caracterizou-se pela autoridade suprema da Igreja organizada e pela abrangente estrutura de poder que ela comandava. A Europa inteira professava uma só religião ${ }^{72}$ e nesse contexto, o direito eclesiástico tinha relevante importância e correlata aplicação com o direito internacional da época.

Como consequência dessa estrutura, temos a centralização do poder de decisão na figura do Papa, chefe espiritual da Cristandade. Suas decisões eram universalmente respeitadas, avocando para si o papel de "árbitro supremo e permanente" de todo período medieval, intervindo ex officio entre as partes em conflito e por muitas vezes conseguindo evitar a guerra entre elas.

A atuação do Papa em intervenções ou mediações em litígios entre príncipes, barões medievais ou mesmo entre ordens religiosas detentoras de extensas propriedades rurais, contribuiu para o fomento da prática da arbitragem ${ }^{73}$ no período, instituto jurídico que posteriormente exerceu um importante papel na Modernidade na solução de disputas entre Estados ${ }^{74}$, como poderá notar-se nos projetos de "paz perpétua" oriundos do período que serão objeto de análise em capítulo próprio.

A Igreja, contrária às guerras privadas entre os príncipes feudais, contribuiu de forma ímpar no sentido de humanizar ${ }^{75}$ as guerras medievais condenando a crueldade de certas práticas, culminando, no final século X, no movimento pela "Paz de Deus":

"Os cavaleiros faziam o juramento de respeitá-la. Ela proibia a
destruição das colheitas e dos instrumentos agrícolas. Ela impunha o
respeito aos camponeses, aos comerciantes, aos peregrinos, às
mulheres, aos viajantes e a todos os seus bens. Foram formadas

\footnotetext{
${ }^{71}$ Muitos autores conferem a este período a denominação de "Respublica Christiana", no sentido de um corpo social hierárquico sob a direção do Papa, chefe da Igreja.

${ }^{72}$ SHAW, Malcom N. op. cit., p. 16.

${ }^{73}$ Observe-se que a arbitragem medieval tinha contornos próprios específicos com natureza de salvaguardas, tais como: o juramento, a ocupação pelo árbitro de castelos e a garantia dada por terceiros.

${ }^{74}$ SOARES, Guido Fernando Silva. op. cit., p. 26.

${ }^{75} \mathrm{~A}$ formação de exércitos permanentes por volta do século XV, também ajudou no desenvolvimento de regras práticas relativas à guerra, concorrendo fortemente para a humanização desta.
} 
diversas “ligas para a manutenção da Paz” (Poitiers,1000). Este instituto de caráter altamente humanitário tinha também um aspecto eminentemente prático, que era o de evitar o flagelo da fome, tão comum no período medieval ${ }^{, 76}$.

Outrossim, no final do século XI, surge a noção de "guerra santa" para justificar a ação das Cruzadas promovidas pelos papas. As Cruzadas também corroboraram para a criação de um sentimento de solidariedade entre as nações cristãs, o que, com o tempo, culminou no surgimento dos princípios de direito internacional.

Em 1027, no Concílio de Elna, foi delineada a “Trégua de Deus”, que proibia a guerra em determinadas horas, dias da semana e estações do ano, no intuito de permitir a todos o cumprimento de seu “dever dominical”. Em 1095, o Papa Urbano II, ao pregar a Cruzada, trouxe uma noção de "guerra santa" para justificar a ação da Igreja. ${ }^{77}$

É justamente na Idade Média que encontramos pela primeira vez a divisão binária clássica do direito internacional em direito da guerra e direito da paz e, por conseguinte, também as noções de guerra justa e guerra injusta receberam novas definições à luz da doutrina cristã.

"O Cristianismo teve influxo essencial no desenvolvimento de um pensamento mais elaborado referente às relações dos povos. Trazia consigo o princípio da unidade do gênero humano, mas, diversamente do cosmopolitismo dos estóicos, conciliou o universalismo com um sentido mais positivo e realista das diferenças históricas (étnicas, linguísticas, religiosas e culturais) dos povos, das gentes, no quadro dessa unidade ${ }^{, 78}$.

Nesse sentido, dentre as numerosas e significativas contribuições dos pensadores do medievo para o desenvolvimento do direito internacional, cabe destacar a formulação de um conceito de guerra justa com base na síntese e na conciliação dos postulados religiosos com os postulados gregos ${ }^{79}$.

\footnotetext{
${ }^{76}$ MELLO, Celso Duvivier de Albuquerque. op. cit., v. 1, p. 156.

${ }^{77}$ Id. Ibid., p. 157.

${ }^{78}$ TRUYOL Y SERRA, Antonio. op. cit., p. 37.

${ }^{79}$ BITTAR, Eduardo C. B.; ALMEIDA, Guilherme Assis de. op. cit., p. 208.
} 
As bases jurídicas da Respublica Christiana encontram-se, principalmente, na obra De Civitate Dei, escrita por Agostinho de Hipona ${ }^{80}$, mais conhecido no ocidente como Santo Agostinho, que contextualizou uma nova forma de conceber o mundo e as relações entre os homens, numa concepção universal da comunidade política, que refletiria claramente a condição jurídica do indivíduo na Idade Média.

Esse ideal de cosmopolitismo tem como base a comunhão fraterna dos fiéis, que se realiza na "Igreja vivente em Cristo". Num momento de grande fragmentação política, foi a teoria de Santo Agostinho que conseguiu criar um vínculo entre os vários ordenamentos e, por isso, perpetuar-se por toda a Idade Média ${ }^{81}$.

Apesar de reconhecido como personagem inerentemente religiosa e devotada aos temas pastorais, Santo Agostinho é criticado por alguns autores acerca da visão utilitarista do Direito Internacional que esposava em relação à Guerra Justa ${ }^{82}$

Por fim, cabe citar alguns fatores que ao final da Idade Média prepararam o terreno para o crescimento e a solidificação das doutrinas e regras do futuro direito internacional clássico, no período da modernidade.

O movimento das Cruzadas fomentou o desenvolvimento do comércio entre o Oriente e o Ocidente, relações essencialmente marítimas, desembocando no nascimento de um verdadeiro direito do mar que vigorava tanto em tempo de paz como em tempo de

\footnotetext{
${ }^{80}$ Agostinho Aurélio (354-430 d.C.) foi teólogo e filósofo e é considerado um dos pais da igreja católica apostólica romana. Por influência de Santo Ambrósio converteu-se ao cristianismo, abandonando o maniqueísmo ao qual tinha aderido por nove anos. Após ter trabalhado em uma série de obras sobre o espiritualismo neoplatônico, foi consagrado bispo de Hipona (391). Dedicou-se principalmente à discussão de temas teológicos e pastorais, polemizando com movimentos heréticos. Suas principais obras são "A cidade de Deus" e "Confissões".

${ }^{81}$ DAL RI JUNIOR, Arno. op. cit., p. 40.

82“"Como os imperadores romanos eram pagãos, a Igreja adotou uma postura pacífica, e até mesmo proibiu os cristãos de se alistar como soldados. Contudo, depois que o Cristianismo havia se tornado a religião oficial do Império, nos tempos de Constantinopla, a Igreja se viu compelida a alterar sua visão sobre a guerra: daquele momento em diante, os cristãos deveriam derramar seu sangue pelo bem do império. Evidentemente, a Igreja teve de encontrar bases teológicas para uma mudança tão radical em seus conceitos fundamentais. Isso foi feito por Santo Agostinho, que reviveu a doutrina do bellum justum como dogma moral. Em sua obra, De Civitate Dei, Santo Agostinho anunciou o princípio fundamental de que guerra era um fenômeno lamentável, mas que os erros provocados pelas mãos do adversário impunham 'a necessidade de se promover a guerra justa' (De Civitate Dei contra Paganos, Livro XIX, § VII)”. DINSTEIN, Yoram. op. cit., p. 89.
} 
guerra, merecendo menções: as "leis de Rodes", a "Tábula Amalfitana", as regras ou "leis de Oléron", o "Consolato del Mare" e as "Leges Wisbuenses" 83.

Outro fator foi a formação das ligas das cidades comerciais para a proteção do comércio e de seus cidadãos, dentre elas a mais famosa foi a "Liga Hanseática", constituída no fim do século XIII. Inclusive, no intuito de proteger os comerciantes "no estrangeiro", surge a instituição dos cônsules em cidades não-cristãs.

Na baixa Idade Média, há também o desenvolvimento da diplomacia com a criação dos "Ministérios dos Negócios Estrangeiros" e das embaixadas permanentes, claramente esse desenvolvimento é oriundo do costume da época de enviar e receber legações permanentes, sendo que no início somente os papas tinham essa prerrogativa.

\section{Os precursores do direito internacional: as doutrinas clássicas}

A expressão "fundadores do direito internacional" foi retirada de uma obra coletiva publicada em 1904, "Les Fondateurs du Droit Internacional”, com célebre introdução de Antoine Pillet ${ }^{84}$.

Optamos pela denominação "precursores", com o recorte metodológico ora efetivado, tendo em mente a contribuição primordial dos autores seguintes, no que diz respeito ao progressivo desenvolvimento do Direito Internacional.

\subsection{Francisco de Vitória (1483-1546)}

Iniciando por um recorte cronológico, reconhecemos, para os fins deste estudo, a personagem de Francisco de Vitória ${ }^{85}$, notoriamente reconhecido como um dos

\footnotetext{
${ }^{83}$ ACCIOLY, Hildebrando. Tratado de direito internacional público, cit., p. 89.

${ }^{84}$ MELLO, Celso Duvivier de Albuquerque. op. cit., v. 1, p. 163.

${ }^{85}$ Francisco de Vitória (1483 - 1546 d.C) foi teólogo neo-escolástico e um dos fundadores da tradição filosófica da chamada "Escola de Salamanca". Entrou na Ordem dos Pregadore em 1504. A dignidade e os problemas morais da condição humana formam o cerne em torno do qual se desenvolveu toda a sua obra. Não escreveu pessoalmente todas as suas obras, pois que algumas delas resultaram apenas de apontamentos tomados pelos seus alunos, e que passaram a circular sob a forma de sebentas.
} 
precursores do Direito Internacional Público ${ }^{86}$, como o conhecemos hoje.

A maior contribuição de Vitória ao Direito Internacional derivou das análises que fez acerca da conquista da América pela coroa espanhola, e das subsequentes guerras travadas com a população indígena que ali residia, consolidada no livro De Indis et de Jure Belli Relectiones ${ }^{87}$.

Vitória rejeitava a premissa de que os índios (considerados pagãos por não ostentarem a fé católica) estivessem, somente por isso, privados de direitos ${ }^{88}$.

Sustentou que, para ser admissível, a guerra contra os índios, assim como contra qualquer outra comunidade, mesmo cristã, deveria ser justa. Partindo dessa premissa, contudo, Vitória considerou justa a guerra empreendida contra as relativamente bem organizadas civilizações indígenas, encontradas nos novos territórios conquistados, em virtude da "resistência injusta" à livre circulação, comércio, e propagação dos ideais cristãos pelos hispânicos ${ }^{89}$.

Em seus argumentos, reelaborou velhas doutrinas, lançando as bases do Direito Internacional e do conceito de Estado soberano modernos, articuladas em três principais vertentes: a) configuração da ordem mundial como sociedade natural de Estados soberanos; b) teorização de uma série de "direitos naturais" dos povos e dos Estados; e c) reformulação da doutrina cristã de guerra justa, que passou a ser entendida como forma de sanção jurídica às injúrias sofridas ${ }^{90}$.

\footnotetext{
86“"Francisco de Vitória, cujo papel proeminente na fundação do direito internacional já é aceito há muito tempo pela crítica historiográfica, é um autor de extraordinária modernidade, em muitos aspectos mais avançado do que aqueles que são conhecidos como outros pais-fundadores que lhe sucederam: Francisco Suarez, Alberico Gentili e Hugo Grotius." FERRAJOLI, Luigi. A soberania no mundo moderno. Tradução: Carlo Coccioli, Marcio Lauria Filho. 2. ed. São Paulo: Martins Fontes, 2007. p. 6.

${ }^{87}$ Traduzida no Brasil como: Os índios e o direito da guerra. Tradução: Ciro Mioranza. Ijuí: Unijuí, 2006.

88“"Avant tout, il pose, comme principe général, que les Indiens, avant l'arrivée des Espagnols, étatient les maîtres lègitimes de leurs choses publiques et privées. Une fois cette proposition ètablie, c'est aux Espagnols à démonstrer la légalité de leur enterprise en Amérique. Dans ce but, Vitoria analyse les raisons alléguées par les Espagnols, à l'appui de leur conduite outre mer et il les classifie sous deux grand titres, à savoir titres illégitgimes par lesquels les ont pu tomber aux mains des Espagnols et titres légitimes par lesquels les barbares ont pu tomber entre le mains des Espagnols. Dans l'analyse de ces trois rubriques, Vitoria expose les principes de droit des gens qui l'ont rendu immortel.' BARCIA TRELLES, Camilo. Francisco de Vitoria et l'ecole moderne du droit international. Recueil des Cours, Haye, t. 17, v. 2, n. 1, p. 196-200, 1927. (Collected Courses of The Hague Academy of International Law).

${ }^{89}$ DINSTEIN, Yoram. op. cit., p. 90.

${ }^{90}$ FERRAJOLI, Luigi. op. cit., p. 7.
} 
O direito à guerra torna-se, assim, o fundamento e o critério de identificação de um Estado, ao qual é reservada a prerrogativa legal de usar licitamente da força (proibição de guerras privadas), sendo, ainda, sinal de sua emancipação da communitas que dominou a Europa medieval.

Por isso, se diz que a moderna sociedade das nações e o moderno direito internacional continuam a repousar sobre as fundações conceituais de Vitória, mais de quinhentos anos depois. Sua inteligência e sua lógica, na elaboração de normas internacionais, moralmente justas e legalmente coerentes, foi sempre equiparada a um agudo senso prático, de realização do possível a seu tempo ${ }^{91}$.

\subsection{Francisco Suarez (1548-1617)}

Praticamente dando continuidade aos pressupostos lançados por Vitória, Francisco Suarez ${ }^{92}$ delineou hipóteses de conflito, e densificou o conceito de guerra justa $^{93}$.

Coube a Suarez, principalmente em sua obra De Legibus, extrapolar formulações a respeito da lei, do direito e da justiça para um âmbito universal, em que as relações entre os Estados são reguladas pelo jus gentium, doutrina de origem romana por ele revisitada a partir dos ensinamentos de Francisco de Vitória.

Sua concepção de sociedade internacional é semelhante à de Vitória, entendendo o surgimento do Direito Internacional como uma necessidade da sociedade.

É considerado um filósofo e jurista de grande envergadura na esfera do Direito Internacional por ser autor de tratados que se dedicavam especificamente a esse

\footnotetext{
${ }^{91}$ ACCIOLY, Hildebrando; SILVA, Geraldo Eulálio do Nascimento e; CASELLA, Paulo Borba. op. cit., p. 644.

${ }^{92}$ Francisco Suarez (1548 - 1617 d.C) foi jesuíta, filósofo e jurista. Nascido de família fidalga, com tradição militar, iniciou seus estudos em Direito na Universidade de Salamanca, que abandonou para ingressar na Companhia de Jesus - ordem dos jesuítas, conhecida por sua forma de organização paramilitar. Tendo tomado o hábito, em 1571, toda a sua vida foi dedicada ao ensino. Começou em Ávila e Segóvia (1575), passando a Valladolid (1576-80), Roma (1580-85), Alcalá (1585-93), Salamanca (1593-97) e, finalmente, em Coimbra (1597-1615), à época em que Portugal e Espanha tiveram fizeram parte do mesmo reino unido.

93 "Segundo Suarez 'qualquer injúria grave contra a honra de alguém' seria causa justa para uma guerra." DINSTEIN, Yoram. op. cit., p. 91.
} 
tema, e não que abordavam, dentre outros assuntos, tal ramo da ciência jurídica, além de ser responsável pela disseminação da disciplina em vários centros de excelência na Europa de sua época ${ }^{94}$.

\subsection{Alberico Gentili (1552-1608)}

De origem italiana, mas posteriormente radicado na Inglaterra, em virtude de perseguições religiosas sofridas por seu pai protestante, na época da inquisição, coube a Alberico Gentili ${ }^{95}$ a contribuição de pregar a secularização do Direito Internacional ${ }^{96}$, até então ainda excessivamente vinculado ao estudo filosófico do jusnaturalismo, com fundamento divino.

Suas obras de Direito Internacional foram De Legationibus Libri Tres, Hispanicae Advocationis Libri Duo, e De Iuri Belli Libri Tres. A Primeira originou-se da consulta da Rainha Elisabeth sobre a legitimidade da prisão do embaixador espanhol, que tramara contra a vida da monarca, ocasião em que sustentou a imunidade dos diplomatas.

\footnotetext{
${ }^{94 ، D e ~ t o u s ~ l e s ~ t h e ́ o l o g i e n s ~ i n t e r n a t i o n a l i s t e s ~ e s p a g n o l s, ~ S u a r e z, ~ c o m m e ~ d i t ~ B r o w n ~ S c o t t, ~ e n ~ e m p l o y a n t ~ u a n ~}$ expression moderne, est celui qui a eu «la melillure presse». Est-ce hasard de fortune? Non; peut-être le serait-ce si Suarez ê̂t passé à la postérité comme un auteur de traités qui abrda spécifiquement l'étude des questions internationales. Ce n'est pas le cas du penser grenadin. Suarez fut un philosophe, et un philosophe de grande envergure. Son ouvre: De legibus, das le pages de laquelle il exposa ses conceptions sur le droit des gens, constitue, pour employer un terme moderne, une véritble encyclpopédie juridique. Cela explique que l'apport de Suarez en tant que philosophe ne puvait être dédaigné par tous ceux qui s'occpèrent d'étudier le trajet de la pensée huamaine. Suarez étaint ainsi uni à la postérité par son apport philosophique personnel, d'accord avec la régle selon laquele l'accessoire suit le pricipal, l'étude de Suarez théologien devait conduire par déduction logique à celle de Suarez. internationaliste.» BARCIA TRELLES, Camilo. Francisco Suarez (1548-1617): les théologiens espagnols du XVI siècle et l'école moderne du Droit international). Recueil des Cours, Haye, v. 43, p. 388-553, 1933. (Collected Courses of The Hague Academy of International Law).

${ }^{95}$ Alberico Gentili (1552-1608 d.C), nasceu de uma família nobre na cidade de San Ginesio, parte da atual região de Marcas (centro da Itália). Estudou Direito na Universidade de Perugia. Foi encarregado de revisar as leis vigentes em sua cidade natal, de onde teve que fugir dois anos depois com seu pai, médico renomado, e com um de seus irmãos, em virtude da fé protestante. Os três foram inicialmente para Ljubljana, capital da Eslovênia, depois para as cidades universitárias alemãs de Tübingen e Heidelberg. Em 1580 chegou à Inglaterra, onde foi nomeado professor catedrático de Direito Civil na Universidade de Oxford. Manteve sua cátedra até a morte, mas dedicou-se cada vez mais à advocacia, tendo sido admitido a oficiar perante a nobilíssima Corte do Almirantado, na qual se aplicava o Direito Civil continental, e não o Direito Comum inglês. Ficou conhecido pelo trabalho desempenhado como advogado da Embaixada da Espanha na Inglaterra.

96“Even before Grotius, Alberico Gentili (author of De Jure Belli, 1598) sustained, by the end of the sixteenth century, that it is Law that regulates the relationships among the members of the universal societas gentium 918. In his De Jure Belli Libri Tres (1612), A. Gentili held that the law of nations was "established among all human beings", being "observed by all mankind." TRINDADE, Antônio Augusto Cançado. op. cit., p. 254.
} 
No Iuri Belli, estabeleceu a diferença entre guerra pública e guerra particular, declarando que somente a primeira é uma luta justa das armas públicas, considerando na guerra privada uma forma de banditismo, sem amparo jurídico qualquer.

Finalmente, em Hispanicae Advocationis, defendeu o direito da Inglaterra de dar asilo a espanhóis que fugissem dos holandeses, e declarou inválido o "Direito à Caça”, pelo qual pretendiam as autoridades holandesas invadir o território inglês em perseguição a seus súditos ${ }^{97}$.

Deve-se em grande parte ao estudo de Alberico Gentili a enunciação da máxima ainda vigente Par in Parem non Habet Imperium - entre pares não há império essencial às relações diplomáticas entre os países ${ }^{98}$.

Durante a vida, suas obras não ganharam tanto destaque, até que, em 1874, foi recuperada pelo professor Erskine Holland, da Universidade Oxford, e em seguida enaltecida pelo jurista italiano Pasquale Mancini.

\subsection{Hugo Grócio (1583-1645)}

Este autor ${ }^{99}$ internacionalista foi responsável pela consolidação definitiva do Direito Internacional como ciência jurídica autônoma, desligada da política, da filosofia

\footnotetext{
${ }^{97}$ MELLO, Celso Duvivier de Albuquerque. op. cit., v. 1, p. 164.

98“"Nacida en él ámbito del derecho internacional público, la regla que aquí evocamos parte de la premisa según la cual el igual no ejercita su autoridad sobre su igual, o sea, que entre pares no hay imperio. Así arribamos a que un Estado no puede válidamente llevar ante sus propios tribunales a su igual, esto es, a otro Estado." ZUCCHERINO, Ricardo Miguel. Derecho internacional privado. Buenos Aires: Lexis Nexis, 2008. p. 182. No mesmo sentido, enaltecendo o papel de Gentili em contenciosos internacionais no século XIX: TETSUYA, Toyoda. Theory and politics of the law of nations: political bias in international law discourse of seven German Court counciliors in the seventeenth and eighteenth centuries. Leiden: Brill, 2011.

${ }^{99}$ Hugo Grócio (1583-1645 d.C), nasceu em Delft, na Holanda. Era um profundo humanista, destacando-se como jurista, filósofo, teólogo, músico, astrônomo, poeta e historiador. Menino prodígio, começou a compor versos aos oito anos e com onze anos entrou para a Universidade de Leidein para estudar Direito. Doutourou-se em 1598, em 5 de Maio, na Universidade de Orleans, ao acompanhar a uma missão diplomática à França Johan van Oldenbarnevelt (advogado, então Primeiro Ministro dos Países Baixos Unidos) Henrique IV, rei da França, comentou que Grócio, que tinha 15 anos, era o verdadeiro "milagre da Holanda"). Sua vida permaneceu aventurosa, pois, em 1632, foi prometida a quantia de 2000 guildes como prêmio por sua cabeça, obrigando-o a fugir em Abril para Hamburgo, na Alemanha, onde passará três anos. Em 1634 foi nomeado pelo conde Axel Oxenstierna Embaixador da Suécia em Paris. Começou a trabalhar em Paris em 1635, ajudando a negociar um tratado para dar fim à Guerra dos Trinta Anos. Ficou ali até ser chamado de volta em 30 de Dezembro de 1644 por carta da Rainha Cristina. Deixou Paris com a família, partindo para Estocolmo, mas em Agosto seu navio naufragou no, e teve que aportar
} 
e, em especial, da teologia ${ }^{100}$.

No Direito Internacional, deixou como legado: De Jure Praede, De Mare Liberum, e De Jure Belli ac Pacis.

De Jure Praede trata do Direito de Presa. Surgiu de uma consulta da Companhia das Índias Orientais, que versava sobre a legitimidade do apresamento de um navio português, Santa Catarina, no estreito de Málaca. Os escrúpulos da companhia se limitavam ao fato de que a Reforma, com seu puritanismo, considerava ímpio qualquer ato de hostilidade. Os seus originais não foram inicialmente publicados, por tratarem de consulta particular. Foram localizados em leilão de 1864, e publicados somente em 1868.

Em Mare Liberum, baseado em excerto do livro anterior, Grócio defende a liberdade dos mares, em que teria o objetivo de defender os interesses da Holanda no comércio com o Oriente, então sob negociação com a Espanha na chamada "Paz da Antuérpia”.

Finalmente, em De Jure Belli ac Pacis, faz o primeiro estudo sistemático de Direito Internacional, em que pese ter ali tratado de assuntos atualmente analisados pelo Direito Internacional Privado.

Nessa obra ele se mostra partidário do que atualmente denomina-se "Escola Eclética" ${ }^{101}$, isto é, daquela corrente de pensamento que concebe a coexistência de direito em outro barco, oito dias depois, dadas as severas tempestades. Morreu de exaustão em Lubeck, na Alemanha. Suas palavras finais teriam sido: "Mesmo tendo compreendido muitas coisas, nada realizei".

100“"Mesmo repropondo a idéia vitoriana de uma universitas societas gentium (comunidade universal das gentes), Grotius, de fato, torna o direito das gentes autônomo não apenas em relação à moral e à teologia, mas também em relação ao direito natural, definindo-o id quod Gentium omnium aut multarum vim obligandi accepit (o que por vontade de todas ou de muitas gentes assume força de obrigação): ou seja, como aquele cuja força obrigatória depende do consenso de todos ou da maior parte dos Estados e, mais exatamente, daqueles que Grotius chama de moratiores (mais civis).” FERRAJOLI, Luigi. op. cit., p. 17-18.

101"Hugo Grotius was well acquainted with natural law doctrine as it was discussed in his contemporary world. His profound and almost universal knowledge included not only theology, classics and law but also, and last but not least, philosophy. Grotius method of dealing with philosophical questions is characterized by a special form of eclecticism. (...) By his eclecticism Grotius not only gained the reputation of being a "homo eruditissimus", a man of highest erudition. There are many authors who consider that Grotius should also be qualified as an outstanding philosopher." AGO, R.; SCHIEDERMAIR, W; RIPHAGEN, A; TRUYOL SERRA; FEENSTRA, R. Commemoration of the Fourth Centenary of the Birth of Grotius. Recueil des Cours, Haye, v. 232, n. 1, p. 399, 1992. (Collected Courses of The Hague Academy of International Law). 
natural ao lado do direito voluntário, sendo que o último não poderia estar em contradição com o primeiro ${ }^{102}$.

Também apresenta um direito comum a todos os povos, válido para a guerra e na guerra, de forma que a paz só possa ser desenvolvida de acordo com normas explícitas, argumentando assim, contra a doutrina da guerra justa e possibilitando a doutrina da mediação e da arbitragem nas questões de guerra e paz, estabelecendo, portanto, um direito de paz para toda a humanidade.

Grócio é por muitos estudiosos do direito, considerado como o responsável pela consolidação definitiva do Direito Internacional como ciência jurídica autônoma, desligada da política, da filosofia e, em especial, da teologia.

\begin{abstract}
"Mesmo repropondo a idéia vitoriana de uma universitas societas gentium (comunidade universal das gentes), Grotius, de fato, torna o direito das gentes autônomo não apenas em relação à moral e à teologia, mas também em relação ao direito natural, definindo-o id quod Gentium omnium aut multarum vim obligandi accepit (o que por vontade de todas ou de muitas gentes assume força de obrigação): ou seja, como aquele cuja força obrigatória depende do consenso de todos ou da maior parte dos Estados e, mais exatamente, daqueles que Grotius chama de moratiores (mais civis) ${ }^{103}$ ".
\end{abstract}

\footnotetext{
${ }^{102}$ MELLO, Celso Duvivier de Albuquerque. op. cit., v. 1, p. 165.

${ }^{103}$ FERRAJOLI, Luigi. op. cit., p. 17-18.
} 


\title{
CAPÍTULO 2. A TRADIÇÃO DOS PROJETOS DE "PAZ PERPÉTUA" NO PENSAMENTO OCIDENTAL
}

\begin{abstract}
"Nunca a mente humana concebeu um esquema mais nobre, mais belo ou útil do que o de uma paz perpétua e universal (...) e nunca um escritor mereceu mais respeito do que quem sugeriu os meios de por em prática esse esquema". (Rousseau)
\end{abstract}

$\mathrm{Na}$ tradição do pensamento ocidental, os denominados projetos de "paz perpétua" possuem por objetivo estabelecer ou manter a paz no plano europeu ou mundial e em sua maioria, apresentam elementos e propostas semelhantes, tais como: a união dos Estados (cristãos ou não) e a utilização da arbitragem para a solução dos conflitos.

Quanto à apresentação dos projetos e a designação nominativa de cada um, em razão da multiplicidade de autores e idiomas, nos quais os textos foram escritos à época da publicação, importante advertir desde logo que se tentou ao máximo preservar a tradução original dos escritos.

Conforme asseverado na introdução, a busca da paz não é uma novidade dos séculos XVII e XVIII. Nesse sentido, servem de paradigmas, alguns autores clássicos, juristas ou não que, de um modo ou de outro, ao longo da história ocidental, pensaram a paz, ou então, propuseram-na como ideal político de contínuo horizonte de busca.

No intuito de adotar a melhor didática para estruturar o capítulo, obedecerá a exposição uma ordem cronológica das contribuições teóricas e dos projetos escolhidos para apresentação. Por fim, insta dizer que, por óbvio esse estudo não tem por pretensão efetuar uma apresentação exauriente e sim conforme preconizado no introito do trabalho.

Ainda quanto à estrutura narrativa ora proposta, salienta-se que ante a relevância e influência dos projetos, reservou-se uma análise em apartado ${ }^{104}$ para os textos de Willian Penn, Abbé de Saint-Pierre e Jean-Jacques Rousseau.

Ante esses apontamentos iniciais, passa-se a apresentação das referidas contribuições teóricas e projetos de paz, de forma contextualizada, na sequência.

${ }^{104}$ As análises dos mencionados projetos se encontram nos sub-capítulos. 
Na Idade Média, mesmo que superficialmente, alguns nomes e textos que corroboraram para o desenvolvimento da investigação da paz. Todavia, imperioso atentar, que toda e qualquer análise sobre o Medievo Ocidental, deve ser realizada sob a ótica de uma herança cristã oriunda do último período do Império Romano.

Assim sendo e à luz da existência de uma única religião organizada e incorporada na figura da Igreja Católica, podemos encontrar a razão da existência de certos institutos jurídicos e correntes doutrinárias de cunho teológico característicos do período em apreço, como é exemplo a escolástica.

Logo, é possível constatar que o cristianismo ${ }^{105}$ inaugurou uma nova forma de conceber o mundo e as relações entre os homens, numa concepção universal da comunidade política que refletiria claramente a condição jurídica do indivíduo no período medieval.

Nesse diapasão, o homem batizado de acordo com os apostolados católicos, torna-se também um ente "investido da personalidade da Igreja", e, por conseguinte, apto a participar da "Casa de Deus". Essa construção tem por base a comunhão fraterna dos fiéis, que se realiza na igreja.

Dentro dessa visão, mesmo sendo considerado um autor de transição, podemos inserir Agostinho de Hipona, mais conhecido no ocidente como Santo Agostinho $^{106}$. Vez que as bases jurídicas da respublica christiana encontram-se principalmente, em sua obra De Civitate Dei (A cidade de Deus - 413-427 d.C).

Para Santo Agostinho, a verdadeira paz só poderia estar no bem, pontuando ainda o autor que, para que fosse verdadeira, a paz não deve estar vinculada apenas às ações, mas também deve ser ela intrínseca a própria a alma do indivíduo.

\footnotetext{
105 “(...) O cristianismo enquanto tal não é uma filosofia. De fato, uma filosofia é constituída pela razão, ao passo que o cristianismo é uma religião revelada. (...) os temas da fé cristã foram realmente o plano de partida de uma reflexão filosófica original (...)", in: VERGEZ, André; HUISMAN, Denis. op. cit., p. 92.

${ }^{106}$ Agostinho Aurélio (354-430 d.C.) foi teólogo e filósofo e é considerado um dos pais da Igreja Católica Apostólica Romana. Por influência de São Ambrósio converteu-se ao cristianismo, abandonando o maniqueísmo ao qual tinha aderido por nove anos. Após ter trabalhado em uma série de obras sobre o espiritualismo neoplatônico, foi consagrado bispo de Hipona (391). Dedicou-se principalmente à discussão de temas teológicos e pastorais, polemizando com movimentos heréticos.
} 
Santo Agostinho, apesar de reconhecido como personagem inerentemente religiosa e devotada aos temas pastorais, é criticado por sua visão do conceito de "guerra justa $^{107}$ - bellum justum”, por ele esposada, conforme bem elucida o trecho em destaque.

\begin{abstract}
"Como os imperadores romanos eram pagãos, a Igreja adotou uma postura pacífica, e até mesmos proibiu os cristãos de se alistar como soldados. Contudo, depois que o Cristianismo havia se tornado a religião oficial do Império, nos tempos de Constantinopla, a Igreja se viu compelida a alterar sua visão sobre a guerra: daquele momento em diante, os cristãos deveriam derramar seu sangue pelo bem do império. Evidentemente, a Igreja teve de encontrar bases teológicas para uma mudança tão radical em seus conceitos fundamentais. Isso foi feito por Santo Agostinho, que reviveu a doutrina do bellum justum como dogma moral. Em sua obra, De Civitate Dei, Santo Agostinho anunciou o princípio fundamental de que guerra era um fenômeno lamentável, mas que os erros provocados pelas mãos do adversário impunham 'a necessidade de se promover a guerra justa' (De Civitate Dei contra Paganos, Livro XIX, $\S$ VII) ${ }^{108, " . ~}$
\end{abstract}

Ainda nesse sentido, cita-se o francês Pierre Dubois (1250-1312), discípulo de São Tomás de Aquino, e sua “De recuperatione Terrae Sanctae”, publicada em 1309, que tinha por objetivo a união dos soberanos cristãos para enfrentar os infiéis e reconquistar os lugares considerados santos para a Igreja Católica.

Quase da mesma época é o tratado “De Monarchia”, de Dante Alighieri, publicado em 1315, no qual o conhecido autor florentino cogitava o estabelecimento de uma monarquia universal ${ }^{109}$.

Outro projeto medieval famoso é o do também francês Antoine Marini adotado pelo Rei da Boêmia, Jorge Podiebrad ou de Podébrady, em 1461. O projeto do autor em tela, prevê a existência de uma Assembleia Confederal que teria competência para declarar a guerra e concluir a paz.

\footnotetext{
${ }^{107}$ Não obstante a opção pela simbólica da paz ocidental como fio condutor da dissertação, achamos interessante colacionar o fragmento em destaque. Importante dizer que no final do século XI surge a noção de "guerra santa" para justificar a ação das Cruzadas promovidas pelos Papas. As Cruzadas, também corroboraram para a criação de um sentimento de solidariedade entre as nações cristãs, o que, com o tempo, culminou no surgimento dos princípios de direito internacional.

${ }^{108}$ DINSTEIN, Yoram. op. cit., p. 89.

${ }^{109}$ ACCIOLY, Hildebrando. Tratado de direito internacional público, cit., v. 2, p. 11.
} 
Em 1517, Erasmo de Roterdã publicou a "Querela Pacis”, obra na qual “a paz" aparece como um ente personificado que defende a sua própria posição. Em a “Querela da paz”, Erasmo esboça a imagem de uma ordem cristã à qual seriam submetidos todos os interesses particulares dos Príncipes e dos Estados.

Ainda que Erasmo aceite a existência de Estados singulares, acima dele ele coloca a republica christiana, a Cristandade que, na opinião do autor, tinha a tarefa de manter ou instaurar a paz por meio de um sistema de acordos e do estabelecimento de tribunais de arbitragem que seriam compostos de estudiosos, sacerdotes e políticos.

Criticando as condições políticas do seu próprio tempo, Erasmo exorta, finalmente, o Papa, o Imperador e os reis, como representantes do príncipe ideal, isto é, Cristo.

A Querela Pacis de Erasmo não surtiu o sucesso imediato e esperado. Apesar disso, essa obra de influenciou muito o pensamento de paz nos séculos seguintes.

Importante destacar a contribuição de Emeric Crucé ${ }^{110}$, monge francês que publicou em Paris (1623) "O Novo Cynée" ou "Discurso sobre as oportunidades e sobre os meios para estabelecer uma paz geral assim como a liberdade de agir em todo mundo ${ }^{111}$ ".

Pautando-se na volatilidade da vontade dos homens, Crucé propõe que a paz seja assinada e organizada de tal maneira que possa ser mantida não somente pela geração que a estabeleceu, mas também pelas gerações futuras.

Em suas meditações sobre a paz, o monge percebe que somente dissertar sobre os benefícios advindos da paz, não seria o suficiente para alcançá-la, prescindo de algo mais audacioso para chegar ao resultado almejado: um verdadeiro plano para paz, um "projeto".

Nesse esteio, Crucé é considerado o primeiro a estabelecer a paz em um caráter verdadeiramente internacional, pois inclui em seu projeto os Estados não cristãos,

\footnotetext{
${ }^{110}$ Segundo biógrafos, dúvidas ainda pairam quanto ao nome verdadeiro do monge francês, encontrando-se em seus escritos as seguintes opções: Émeric Crucé, Émeric Lacroix, Crucaeus, Cruceus ou ainda Crucejus. Poucos detalhes sobre sua vida são conhecidos, inclusive sua data de nascimento, entretanto, considera-se que ele tenha nascido por volta de 1590 vivendo até aproximadamente 1648.

${ }^{111}$ Tradução do original em francês: "Le Nouveau Cynée" ou "Discours d'État représentant les occasions et moyens d'etablir une paix générale et la liberte de commerce par tout le monde", in LEDERMANN, László. Les précurseurs de l'organisation internacionale. Nêuchatel: Èditions de la Baconnière, 1945. p. 69.
} 
por crer que as nações estão associadas por um laço natural e, consequentemente, indissolúvel que independe da religião.

Em seu "projeto de paz", prevê um Conselho Permanente com sede em Veneza. Propõe, também, a intensificação das trocas comerciais além do estabelecimento de um sistema monetário mundial único.

Ressalte-se que o autor escreveu seu "projeto de paz" inspirado por um pacifismo profundo. Sonhava que os homens pudessem transitar entre os mais diversos países sem dificuldades, podendo-se comunicar, sem preconceitos regionais, visando que o planeta Terra fosse um local comum a todos, uma espécie de cidade global.

Outro pensador desta época é Maximiliano de Béthune, mais conhecido como Duque de Sully, ministro do Rei Henrique IV, cujo projeto ${ }^{112}$ foi escrito entre 1611 e

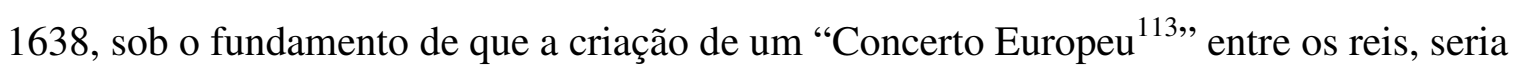
vantajoso tanto para os soberanos como para seus súditos.

Sucintamente, seu escrito visava à destruição da hegemonia da Casa da Áustria ${ }^{114} \mathrm{e}$, consequentemente, o estabelecimento de um equilíbrio europeu. O equilíbrio dar-se-ia por meio de uma espécie de Federação ${ }^{115}$ entre os reis (associados), que seria regida por um conjunto de normas e princípios estruturados.

\footnotetext{
${ }^{112}$ Em anexo ao presente trabalho, há uma ilustração de um mapa de reorganização da Europa proposto pelo Duque de Sully.

113“Sempre fui de opinião [diz o Duque de Sully a Henrique IV] que os Reis de França não devem jamais aspirar a fazer conquistas contra os Príncipes seus vizinhos, pois isso suscita os ciúmes, a inveja e o ódio de todos os demais, e eles se verão obrigados a despesas tão grandes que esmagarão seus povos por meio de taxas e impostos, e finalmente acabarão por se arrepender por não se contentarem com um Estado grande, esplêndido, fértil e populoso como o que possuem, a fim de cuidá-lo com o amor e boavontade de seus povos e do qual se pode usufruir tão bem que fornecerão sempre em abundância tesouros e riquezas, e desde agora Vossa Majestade conquistará a reputação de ser o Príncipe mais amado, sábio, venturoso e político que existe em todo o Universo". BÉTHUNE apud SAINT-PIERRE, Abbé de. Projeto para tornar perpétua a paz na Europa. Tradução: S. Duarte. São Paulo: Imprensa Oficial; Brasília: Ed. da UnB, 2003. p. 661. (Coleção Clássicos IPRI).

114“Página 407 na representação aos Príncipes da Casa de Áustria reinantes na Espanha. Que já não mais estando por conseguinte obrigados a qualquer despesa para defender e conservar seus Estados, poderiam governar pacificamente todos esses belos Estados e aperfeiçoá-los simultaneamente, de forma a diminuir de tal maneira suas despesas que suas economias montariam ao dobro de suas quotas-parte dos recursos e contribuições para a manutenção dos exércitos gerais da Cristandade contra os turcos." Id. Ibid., p. 665.

115“Artigo VI. Nenhum dos Associados poderá usar de agressão ou conquistar terras de outrem sem o consentimento dos Associados, e mesmo quando houver conquistado alguma coisa, terá obrigação de colocá-la à disposição de todos os demais." Id., loc. cit.
} 
Cada membro da Federação não poderia abandoná-la, sob pena de sofrer sanções ${ }^{116}$, inclusive de cunho violento, por parte dos outros membros. A Federação seria composta por grupos regionais e sua direção seria realizada em conjunto pelos membros.

O Duque de Sully relata em sua obra que a proposta por ele sistematizada, originariamente idealizada pelo próprio rei Henrique IV, obteve considerável aceitação já naquela época por outros reis da Europa ${ }^{117}$.

O projeto em apreço, também trazia uma proposta de livre comércio para seus associados (reis participantes da Federação), prevendo inclusive, a elaboração de um regramento comum para a livre navegação nos mares ${ }^{118}$.

Os eventuais conflitos surgidos nesse "Concerto Europeu" seriam resolvidos por meio da arbitragem, conduzida pelos membros da Federação, com tomada de decisões por maioria de $\operatorname{votos}^{119}$.

\footnotetext{
116“"Uma vez estabelecida a República Muito Cristã, nenhum dos Associados poderá deixá-la ou dela separar-se sem atrair contra si a má-vontade de todos os demais e até mesmo a agressão deles mediante guerra, se for o caso." SAINT-PIERRE, Abbé de. op. cit., p. 666.

"Artigo 19 da instrução. Página 399. Tomo 3. Mais: convir que se algum dos que assinarem a associação vierem a separar-se ou a desinteressar-se dela, serão perseguidos como inimigos por todos os demais conjuntamente." Id. Ibid., p. 667.

117، "Página 458 do Tomo 3. Parece que o Rei James, e sobretudo o Príncipe de Gales, encantaram-se com o projeto de Sociedade Européia proposto por Henrique IV a fim de tomar perpétua a paz e expulsar os turcos da Europa.

Que as Províncias Unidas e o Rei da Dinamarca haviam aprovado o projeto desde 1605.

Que o Rei da Suécia se mostrou mais entusiasmado do que qualquer outro com esse desígnio.

Que a Nobreza, as Cidades e Povos da Hungria, Baixa-Áustria, Boêmia, Morávia, Silésia e Luzácia, às primeiras notícias deste projeto afirmaram terem maior necessidade de retenção do que de demanda.

Que a Senhoria de Veneza disse considerar uma glória seguir os magníficos desígnios de tão grande Rei. Que o Duque de Savoia desejava impacientemente sua execução.

Que os Príncipes e Cidades Imperiais Protestantes da Germânia e os suíços também afirmaram aprovar esses desígnios.

Menciona-se que Henrique negociou com o Papa em 1605 a respeito do projeto, assim como com o Duque da Baviera, com o Duque de Saxe e com os Eleitores Católicos, com o Duque de Florença, com o Duque de Mantua, de Modena, com Gênova e Luca." Id. Ibid., p. 671-672.

118، Página 68. Parece adequado estabelecer um ordenamento para a navegação, especialmente no que diz respeito às viagens de longo curso, para que o mar seja tão livre quanto a terra para todos os Estados Cristãos e para que tenham igualdade de tráfego e comércio em todas as Índias e outros lugares." Id. Ibid., p. 675.

${ }^{119}$ Artigo 10 da instrução. Página 398. Tomo 3. Além disso, convir com os associados que se houver divergências entre eles, deverão confiar a decisão à Arbitragem de seus amigos comuns, que a julgarão por maioria de votos sem luta." Id. Ibid., p. 667.
} 
Nesse ponto, Sully preconiza que a arbitragem é o único método eficaz de resolução de conflitos a ser adotado, por decorrer de motivos fundados na própria natureza humana ${ }^{120}$.

As ideias do autor serviram de inspiração para o projeto de paz perpétua do Abbé de Saint-Pierre, cuja análise consta neste capítulo, tanto que o religioso dedicou em sua obra um excerto intitulado "Das memórias do Duque de Sully sobre o grande projeto de Henrique, o Grande, para estabelecer na Europa uma Organização Geral, uma Arbitragem Permanente e uma proteção recíproca entre os Soberanos Cristãos ${ }^{121}$ ”.

Jurista inglês conhecido, Jeremy Bentham, também escreveu um projeto de "paz perpétua" intitulado "Um Plano para uma Paz Universal e Perpétua", que é parte integrante dos ensaios encontrados em seus Principles of International Law, publicados postumamente em 1843.

Em seu projeto, Bentham, traz duas propostas fundamentais ${ }^{122}$ : reduzir e fixar as forças de cada nação que compõe o sistema europeu e emancipar as colônias de cada uma.

Outras ideias abordadas pelo autor em sua obra são: a publicidade com a supressão da diplomacia secreta; a necessidade de uma codificação do Direito Internacional $^{123}$ e a proibição de medidas que ofendam a liberdade de comércio.

\footnotetext{
120"(...) a convenção de Arbitragem Europeia não será apenas possível, mas será impossível que a longo prazo, em circunstâncias favoráveis durante as diferentes crises dos Estados, quando essas reflexões salutares sobre as imensas vantagens de uma organização geral se tornarem comuns, eles não resolvam finalmente acordar uma Arbitragem permanente para resolver suas controvérsias futuras.

Dessa forma, já não me contento em dizer que esse Tratado é muito factível e que essa instituição é muito praticável e que é muito possível; sustento agora, por motivos de proporção fundados na própria natureza humana, que é absolutamente impossível que um dia ele não seja executado. A única coisa incerta é o momento em que será executado, e ouso dizer que esse momento está mais próximo do que se acredita." SAINT-PIERRE, Abbé de. op. cit., p. 686-687.

${ }^{121}$ Id. Ibid., p. 658.

${ }^{122}$ The following plan has for its basis two fundamental propositions:--1. The reduction and fixation of the force of the several nations that compose the European system; 2. The emancipation of the distant dependencies of each state. Each of these propositions has its distinct advantages; but neither of them, it will appear, would completely answer the purpose without the other." BENTHAM, Jeremy. Essay IV: a plan for an universal and perpetual peace (1843), from The Works of Jeremy Bentham v. 2, edited by John Bowring (Edinburgh: William Tait, 1843). Disponível em: <http://perpetualpeaceproject.org/resources/bentham.php>. Acesso em: 21 mar. 2013.

${ }^{123} \mathrm{~A}$ expressão "Direito Internacional" hoje consagrada como a nomenclatura da disciplina, é relativamente recente. Tal designação é oriunda de international law, que fora utilizada pela primeira vez pelo autor em 1780 no livro "Introduction to the Principles of Morals and Legislation",em oposição aos termos national Law ou municipal law. Segue o trecho.
} 
Importante destacar, que o inglês reconhece os proveitos econômicos e as vantagens advindas das colônias européias, todavia, pugna pela desistência de todas pelos países, em razão dos seguintes motivos: economizar os custos civis e militares com defesa do território colonial; evitar o perigo da guerra por estar forçando a obediência dos colonos e por fim diminuir a corrupção na esfera pública além de simplificar o quadro de funcionários do governo.

No que tange a fixação e redução dos exércitos nacionais ${ }^{124}$, o autor considera tal medida honrosa e não humilhante para os países, pois a redução não seria imposta a um país somente, mas a todos.

Ademais, Bentham sustenta em seu "projeto de paz", a criação de um Congresso Europeu, para o qual cada nação enviaria dois deputados. As sessões do Congresso seriam públicas e também seria de competência desse Congresso emitir opiniões e divulgá-las nos domínios de cada Estado individualmente.

BENTHAM, Jeremy. An introduction to the principles of morals and legislation, cit., p. 326-328, Chapter XVII - Of the Limits of the penal branch of Jurisprudence.\$ 2. Jurisprudence, it branches. Jurisprudence, local-universal-internal and internacional.

(...) $\underline{X X V}$. In the second place, with regard to the political quality of the persons whose conduct is the object of law. These may, on any given occasion, be considered either as members of the same state, or as members of different states: in the fist case, the law may be referred to the head of internal, in the second case, to that of international jurisprudence.

Now as to any transactions which may take place between individuals who are subjects of different states, these are regulated by internal laws, and decided upon by the internal tribunals, of the one or the other of states: the case is the same where the sovereign of the one has any immediate transactions with a private member of the other: the sovereign reducing himself, pro re natâ, to the condition of a private person, as often as he submits his cause to either tribunal; whether by claiming a benefit, or defending himself against a burthen. There remain then the mutual transactions between sovereigns, as such, for the subject of that branch of jurisprudence which may be properly and exclusively termed international.

With what degree of propriety rules for the conduct of persons of this description can come under the appellation of laws, is a question that the must rest till the nature of the thing called a law shall have been more particulary unfolded.

It is evident enough, that international jurisprudence may, as well as internal, be censorial as well as expository, unauthoritative as well as authoritative. - Id. Ibid., p. 326-327.

$\underline{X X V I . ~ I n t e r n a l ~ j u r i s p r u d e n c e, ~ a g a i n, ~ m a y ~ e i t h e r ~ c o n c e r n a l l ~ t h e ~ m e m b e r s ~ o f ~ a ~ s t a t e ~ i n d i s c r i m i n a t e l y, ~ o r ~}$ such of them only as are connected in the way of residence, or otherwise, with a particular district. Jurisprudence is accordingly sometimes distinguished into national and provincial. But as the epithet provincialis hardly applicable to the districts so small as many of those which have laws of their own are wont to be, such as towns, parishes, and manors; the term local (where universal jurisprudence is plainly out of question) or the term particular, though this latter is not very characteristic, might either be more commodious. - Id. Ibid., p. 327-328.

${ }^{124 ، " W h a t s o e v e r ~ n a t i o n ~ s h o u l d ~ g e t ~ t h e ~ s t a r t ~ o f ~ t h e ~ o t h e r ~ i n ~ m a k i n g ~ t h e ~ p r o p o s a l ~ t o ~ r e d u c e ~ a n d ~ f i x ~ t h e ~ a m o u n t ~}$ of its armed force, would crown itself with everlasting honour. The risk would be nothing--the gain certain. This gain would be, the giving an incontrovertible demonstration of its own disposition to peace, and of the opposite disposition in the other nation in case of its rejecting the proposal. The utmost fairness should be employed. The nation addressed should be invited to consider and point out whatever further securities it deemed necessary, and whatever further concessions it deemed just." Id. Ibid. 


\subsection{William Penn: "Ensaio para uma paz presente e futura da Europa por meio da} fundação de uma Assembleia, um Parlamento ou uma Câmara de Estados da Europa"

William Penn ${ }^{125}$, autor inglês e considerado o "pai espiritual” dos Quackers ${ }^{126}$ americanos, possui uma vasta produção literária. Além de seu "projeto de paz perpétua", objeto do presente estudo, escreveu muitos textos de temática cristã, a maioria em defesa do mencionado grupo religioso.

A primeira publicação ${ }^{127}$ do "Ensaio para uma Paz Presente e Futura da Europa por meio da fundação de uma Assembleia, um Parlamento ou uma Câmara de

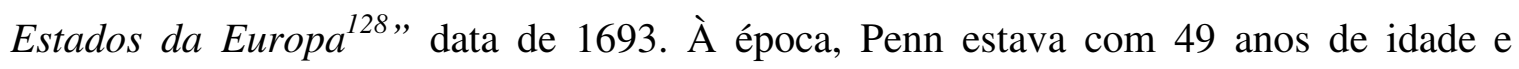
esperava que a "proposta de seu projeto", pudesse efetivamente ajudar a desenvolver uma paz com justiça na Europa ${ }^{129}$.

Em apertada síntese, o autor propõe que os soberanos europeus deveriam estabelecer um Parlamento dotado de poder coercitivo e de representação ponderada $^{130}$. Participariam desse Parlamento cerca de noventa estados ${ }^{131}$, que deveriam pautar suas relações em uma ordem política corporativa fundamentada no direito e na renúncia à violência.

\footnotetext{
${ }^{125}$ William Penn é lembrado na história moderna como o fundador da Pensilvânia, um dos 50 Estados dos Estados Unidos da América. Em 1682, Penn foi nomeado pelo rei Charles II, proprietário e governador da região. A palavra que dá origem ao nome Pensilvânia, deriva de "Penn's woods" (floresta de Penn).

${ }^{126}$ Os Quackers ou "The Society of friends" é a designação dada aos grupos religiosos oriundos do movimento protestante britânico do século XVII. Penn tornou-se um quacker em 1667. Resumidamente, os "quackers" possuem por doutrina religiosa viver em recolhimento a pureza moral, a prática ativa do pacifismo, da solidariedade e da filantropia. De bom alvitre dizer, que em 1947 os comitês ingleses e americanos do "Auxílio Quacker Internacional” receberam o prêmio Nobel da Paz.

${ }^{127}$ Importante dizer, que o escrito de William Penn acerca de uma "possível paz presente e futura para a Europa", foi praticamente ignorado por quase dois séculos. Contudo, o texto começou a ser novamente editado com o início da Primeira Guerra Mundial.

${ }^{128}$ Tradução do original: An Essay Towards the Present and Future Peace of Europe by the Establishment of anEuropean Dyet, Parliament or Estates. Também são encontradas, mais comumente na literatura afeta ao tema de "paz perpétua", formas compactadas da designação do projeto de William Penn, tais como: "Ensaio para conseguir a Paz Presente e Futura da Europa", "Ensaio para chegar à paz presente e futura da Europa" ou ainda "Projeto para chegar à paz presente e futura da Europa".

${ }^{129}$ Penn utiliza a expressão "este quarto (1/4) do mundo" para se referir ao continente Europeu.

${ }^{130}$ TRUYOL Y SERRA, Antonio. op. cit., p. 100.

${ }^{131}$ Digno de nota dizer, que quando da redação do projeto, Penn foi a favor da admissão do Império Otomano e da Rússia.
} 
Sob o influxo desses apontamentos, será apresentada uma análise do "ensaio de paz" de Willian Penn, respeitando-se a estrutura ternária de sua redação original, que o divide em: prefácio, capítulos (dez ao todo) e conclusão.

Em seu prefácio, o autor, por meio da epígrafe “Ao leitor”, expõe os motivos que o motivaram escrever um "ensaio de paz". Todavia, admite de pronto, que a tarefa de que se incumbe é extremamente árdua, dizendo que tal empreitada merece um mestre muito mais gabaritado do que ele por tratar-se de assunto tão importante.

Após o prefácio, seguem os dez capítulos do "Ensaio para uma paz presente e futura da Europa por meio da fundação de uma Assembleia, um Parlamento ou uma Câmara de Estados da Europa”.

\section{CAPÍTULO PRIMEIRO - Da paz e suas vantagens.}

O autor inicia seu ensaio no primeiro capítulo com uma indagação reflexiva: se não existe a paz no mundo não pode existir outra coisa que a humanidade poderia desejar.

A partir dessa indagação, Penn demonstra que a paz antes de tudo, possibilitaria um meio fértil para a caridade e a hospitalidade entre os Estados. Ainda nesse sentido e em contrapartida de forma figurativa, a guerra seria como uma geada que tomaria das pessoas todos os confortos propiciados pela paz estabelecida ${ }^{132}$.

Destaque-se, que a paz tem o condão de conservar os bens materiais dos Estados, de forma que a riqueza acumulada possa ser futuramente investida e distribuída entre os mesmos ${ }^{133}$.

\footnotetext{
132،(...) What can we desire better than peace, but the grace to use it? Peace preserves our possessions; we are in no danger of invasions: our trade is free and safe, and we rise and lie down without anxiety. The rich bring out their hoards, and employ the poor manufacturers: buildings and diverse projections, for profit or pleasure, go on: it excites industry, which brings wealth, as that gives the means of charity and hospitality, not the lowest ornaments of a kingdom or commonwealth. But war, like the frost od '83, sizes all these comforts at once, and stops the civil channel of society." in PENN, William. The peace of Europe, the fruits of solitude. Great Britain: Everyman, 1993. p. 6.

133“"(...) Justice is the means of peace, betwixt the government and the people, and one man and company and another. It prevents strife, and at last ends it: for besides shame or fear, to contend longer, he or they being under government, are constrained to bound their desires and resentment with the satisfaction the
} 


\section{CAPÍTULO SEGUNDO - Dos significados da paz: a justiça no lugar da guerra.}

Neste segundo momento, o autor disserta sobre a justiça como fruto do governo interno de cada país, da sociedade e da concordância geral dos estados, como grande garantidora da paz. Haja vista, que ante a existência de uma "justiça acreditada", os indivíduos são forçados a pautar seus desejos e ressentimentos por meio das limitações impostas pela lei ${ }^{134}$.

\section{CAPÍTULO TERCEIRO - Do governo, o começo e o fim de todos os modelos.}

Pela leitura desse capítulo, observa-se que o autor analisa o governo como uma ferramenta contra os excessos cometidos pelos indivíduos. O cerne de seu argumento encontra guarida na ideia de que fora da sociedade cada indivíduo é o seu "próprio soberano" e faz o que deseja por sua conta e risco. No entanto, ao submeter-se à conveniência do todo, o indivíduo efetua uma troca: os seus arbítrios pela proteção oferecida pelo governo $^{135}$.

\section{CAPÍTULO QUARTO - De uma paz geral: a paz da Europa e seus significados.}

Pode-se afirmar que o quarto capítulo traz a ideia central do "projeto de paz perpétua", visto que é justamente nele que o autor aduz que os príncipes soberanos da Europa, deveriam reunir-se em uma "Assembleia Europeia" ou "Parlamento" para estabelecer regras de convívio. Argumenta ainda, que todos os conflitos entre os

\footnotetext{
law gives. Thus peace is maintained by justice, which is a fruit of government, as government, is from society, and society from consent." PENN, William. op. cit., p. 7-8.

134“(...) Justice is the means of peace, betwixt the government and the people, and one man and company and another. It prevents strife, and at last ends it: for besides shame or fear, to contend longer, he or they being under government, are constrained to bound their desires and resentment with the satisfaction the law gives. Thus peace is maintained by justice, which is a fruit of government, as government, is from society, and society from consent." Id., loc. cit.

135“Government is an expedient against confusion; a restriction upon all disorder; just weights and even balance: that one may not injure another, nor himself, by intemperance. (...) No man is judge in his own cause, which ends the confusion and blood of so many judges and executioners. For out of society every man is his own king, does what he lists, at his own peril. But when he comes to incorporate himself, he submits that royalty to the convenience of the whole, from whom he receives the returns of protection. (...)" Id. Ibid., p. 8.
} 
príncipes soberanos deveriam ser submetidos a essa Assembleia e a solução de cada conflito seria de competência da última impreterivelmente ${ }^{136}$.

Por fim, Penn suscita que na hipótese de algum soberano recusar se submeter ao mecanismo acima proposto e buscar resolver seu conflito por meio da violência, todos os outros soberanos deveriam compelir o faltoso a obedecer ao que fora decidido pela Assembleia, vez que ela representa a vontade da maioria ${ }^{137}$.

\section{CAPÍTULO QUINTO - Das causas dos conflitos e os motivos da violação da paz.}

O quinto capítulo explana acerca das três formas legítimas, enunciadas pelo autor, em que se poderia autorizar uma interrupção do "estado de paz". Seguem as hipóteses elencadas no projeto:

(a) para manter o que é de direito do estado contra a invasão de um inimigo em seu território;

(b) para a recuperação de uma posse perdida do estado e;

(c) para aumentar o domínio territorial do estado, por meio da aquisição do território de país vizinho (fronteiriço) ${ }^{138}$.

\footnotetext{
${ }^{136}$ Ainda no tocante as reuniões da Assembleia, o autor de forma minuciosa, sugeriu que essas deveriam ocorrer em uma sala redonda dotada de várias portas, para que representante pudesse adentrá-la e retirarse, quando quisesse sem maiores constrangimentos.

137،(...) Now if the sovereign princes of Europe, who represent that society, or independent state of men that was previous to the obligation of society, would, for the same reason that engaged men first into society, viz. love of peace and order, agree to meet by their stated deputies in a general diet, estates, or parliament, and there establish rules of justice for sovereign princes to observe one to another; (...) before which sovereign assembly, should be brought all differences depending between one sovereign and another (...) and if any of the sovereignties that constitute these imperial states, shall refuse to submit their claim or pretensions to them, or to abide and perform a judgment thereof, and seek their remedy by arms, or delay their compliance beyond the time prefixed in their resolutions, all the other sovereignties, united as one strength, shall compel the submission and performance of the sentence. (...)" PENN, William. op. cit., p. 9.

138“"There appears to me but three things upon which peace is broken, viz. to keep, to recover, or to add. First, to keep what is one's right, from invasion of an enemy; in which I am purely defensive. Secondly, to recover, when I think myself strong enough, that which by violence, I, or my ancestors have lost, by the arms of a stronger power; in which I am offensive: or, lastly, to increase my dominion by the acquisition of my neighbor's countries. (...)" Id. Ibid., p. 10.
} 


\section{CAPÍTULO SEXTO - Dos títulos nobiliários e os conflitos que eles podem gerar.}

Ao dedicar um capítulo inteiro aos "títulos nobiliários", podemos notar que o autor preocupou-se em tratar de um problema latente na época da feitura de seu "projeto". Aqui, ele alerta sobre os conflitos que podem emergir em razão dos títulos de nobreza, que levaram determinados príncipes soberanos ao poder. Pois, alguns desses títulos foram conquistados com o uso da violência ${ }^{139}$.

\section{CAPÍTULO SÉTIMO - Da composição dos Estados Imperiais.}

O Sétimo Capítulo, retrata a preocupação do autor sobre a dificuldade em atribuir peso ao voto de cada príncipe soberano na Assembleia. Diante desse problema, Penn propõe um sistema, no qual cada país da Europa deveria ser representado na Assembleia de acordo com o seu poderio econômico ${ }^{140}$.

\section{CAPÍTULO OITA VO - Da regulamentação dos Estados Imperiais.}

O Capítulo aborda a questão do quórum das votações na Assembleia. Restando estabelecido no projeto que qualquer decisão deveria ser aprovada por três quartos (3/4) dos votos. Penn, ao determinar um quórum qualificado para as deliberações, acreditava que dificultaria possibilidades de traição e corrupção entre os participantes.

\footnotetext{
${ }^{139}$ "But I easily foresee a question that may be answered in our way, and that is this: what is right? or else we can never know what is wrong: it is very fit that this should be established. But that is fitter for the sovereign states to resolve than me. And yet I may lead a way to the matter, I say that this title is either by a long and undoubted succession, (...) or by election, (...) or by marriage, (...) or by purchase, (...) or by conquest. (...) This last, title is, morally speaking, only questionable. (...)" PENN, William. op. cit., p. 10.

140“"The composition and proportion of this sovereign part, or imperial state does, at the first look, seem to carry with it no small difficulty what votes to allow for the inequality of the princes and states. But with submission to better judgments, I cannot think it is invincible: for if it be possible to have an estimate of the yearly value of several sovereign countries. (...)" Id. Ibid., p. 11.
} 


\section{CAPÍTULO NONO - Das objeções que podem arruinar o sistema.}

De forma meticulosa, o autor reservou este capítulo para responder possíveis "objeções in abstrato"141 que seu projeto "para uma paz presente e futura da Europa" poderia receber, aventando quatro perquirições, quais sejam:

Primeira Objeção: Enuncia que a mais rica e forte soberania da Europa jamais aceitaria um "projeto" nos termos expostos por Willian Penn.

Resposta: Com argumentos coesos advindos da ideia central de sua própria "proposta de paz", o autor consegue rebater tal objeção afirmando que a mais rica e forte soberania da Europa, isoladamente, não seria mais forte do que todas as outras soberanias juntas.

Segunda Objeção: O autor indaga si próprio acerca da fragilidade das soberanias ante a ausência de exércitos nacionais permanentes.

Resposta: O inglês tenta mostrar ao leitor um argumento contrário: as soberanias ficariam mais fortes na hipótese da ausência de exércitos nacionais permanentes. Ele fundamenta sua resposta baseando-se no remanejamento dos recursos financeiros do estado, uma vez que a receita utilizada na manutenção dos exércitos permanentes poderia ser utilizada na educação da juventude.

Interessante notar que essa educação preconizada pelo autor seria pautada pela vida simples e pelo trabalho justo, em clara sintonia com os princípios quackers esposados pelo último, em seus dizeres: "educando-os na filosofia natural, nos conhecimentos mecânicos e na arte, as gerações do porvir serão formadas por homens e não por leões ${ }^{142,}$.

Terceira Objeção: Esta objeção é a continuação da segunda objeção, pois há ainda um questionamento acerca dos reflexos decorrentes da falta de um exército permanente: a falta de um exército permanente poderia fatalmente atingir de forma imediata os jovens pobres da sociedade? Esses jovens estariam fadados à criminalidade?

\footnotetext{
${ }^{141}$ Importante esclarecer que essas objeções foram formuladas pelo próprio autor no intuito de detectar possíveis falhas e rebater futuras críticas de seu "projeto de paz".

${ }^{142}$ PENN, William. op. cit., p. 14.
} 
Resposta: William acredita que já rebateu a terceira objeção em sua resposta anterior. Entretanto, acrescenta que o empenho das soberanias na formação dos jovens da sociedade, no mínimo, possibilitaria aos pobres não mais ter que escolher entre ser soldado ou bandido.

Quarta Objeção: A última objeção abrange a questão da perda do caráter soberano dos príncipes participantes da Assembleia.

Resposta: $A b$ initio, o autor considera falsa tal objeção. Pois, em seu entendimento, os príncipes continuariam soberanos como sempre foram em seus territórios $^{143}$.

\section{CAPÍTULO DÉCIMO - Dos benefícios consectários dessa Proposta de Paz.}

O último capítulo é o corolário reflexivo do autor sobre os benefícios advindos do cumprimento de seu "projeto de paz perpétua" pelos países integrantes da Assembleia de Estados por ele imaginada. Nesse sentido, ele elenca vários benefícios oriundos da manutenção do "estado de paz", dentre os quais merecem menção os que seguem.

O primeiro benefício arrolado por Penn é de ordem espiritual e religiosa fundada na doutrina cristã, sendo possível constatar aqui, que o autor em apreço, bem como seu projeto em análise, são frutos de seu tempo e também de sua convicção religiosa.

\footnotetext{
${ }^{143 ،(. . .)}$ The strongest and richest sovereignty will never agree to it, and if it should, there would be danger of corruption than of force one time or other. I answer to the first part, he is not stronger than all the rest, and for that reason you should promote this, and compel him in to it, especially before he be so, for then, it will be to late to deal with such an one. (...) The second is that it will endanger an effeminacy of such a disuse of the trade of soldiery: that if there should be any need for it, upon any occasion, be at a loss as they were in Holland in '72. There can be no danger of effeminacy, because each sovereignty may introduce as temperate or severe a discipline in the education of youth, as they please, by low living, and due labour. Instruct them in mechanical knowledge, and natural philosophy, by operation, which is the honour of the German nobility. This would make them men: neither women nor lions: for soldiers are the other extreme of effeminacy. (...) The third objection is, that there will be great want of employment for younger brothers of families; and that the poor must either be soldiers or thieves. I have answered that in my return to the second objection. We shall have the more merchants and husbandmen, or ingenious naturalists, if the government be but any thing solicitous of the education of their youth. (...) To the last objection, that sovereign princes and states will hereby become not sovereign; a thing they will never endure. But this also, under correction, is a mistake, for they remain as sovereign at home as they ever were. (...)" PENN, William. op. cit., p. 14-15.
} 
Outro benefício apontado pelo autor é a contenção de gastos dispendidos com a preparação de um exército permanente para futuras guerras. Ainda, de forma não exauriente, outros benefícios consequentes da "paz advinda do projeto" seriam: prevenir a destruição de vilarejos nas fronteiras, as viagens tornarem-se mais pacíficas e seguras nos territórios estrangeiros, promover o cristianismo, além do estreitamento dos laços de amizade entre os príncipes soberanos ${ }^{144}$.

Em sua conclusão, William Penn realiza uma síntese dos argumentos apresentados nos capítulos e no prefácio de seu "Ensaio para uma paz presente e futura da Europa por meio da fundação de uma Assembleia, um Parlamento ou uma Câmara de Estados da Europa".

Nesse sentido, insta destacar que o autor declara que os princípios da justiça e da prudência devem estar presentes em todo e qualquer governo, em especial no continente europeu. Pois, é por esse binômio que as famílias, estados e príncipes devem ser governados em nome da conservação da paz.

$\mathrm{Na}$ concepção de que "os reinos e estados impedem os homens de serem juízes de si, anulando as paixões individuais e submetendo todos às regras da justiça, a Europa pode obter e manter a paz entre as soberanias ${ }^{145}$ ".

Por fim, propõe que os assuntos de guerra sejam julgados e avaliados por um conselho imparcial dotado de autonomia governamental, vez que, "jamais e em tempo

\footnotetext{
${ }^{144}(. .$.$) Let it not. I pray, be the least, that it prevents the spilling of so much human and Christian blood:$ for a thing so offensive to God, and terrible and afflicting to men, as that has ever been, must recommend our expedient beyond all objections, For what can a man give in exchange for his life, as well as soul? And though the chiefest in government are seldom personally exposed, yet it is a duty incumbent upon them to be tender of the lives of their people, since without a doubt, they are accountable to God for the blood that is spilt in their service. So that besides the loss of so many lives, of importance to any government, both fou labour and propagation, the cries of so many windows, parents and fatherless are prevented, that cannot be very pleasant in the ears of the government, and is the natural consequence of war in all government. (...)" PENN, William. op. cit., p. 16.

145"I will conclude this my proposal of an European, sovereign, or imperial diet, parliament, or estates, with that which I have touched upon before, and which falls under the notice of every one concerned, by coming home to their own sovereignties. That by the same rules of justice and prudence, by which parents and masters govern their families, and magistrates their cities, and estates their republics, and princes and kings their principalities and kingdoms, Europe may obtain and preserve peace among her sovereignties. For wars are the duels of princes; and as government in kingdoms and states, prevents men being judges and executioners for themselves, overrules private passions as to injuries or revenge, and subjects the great as well as the small to the rule of justice, that power might not vanquish or oppress right, nor one neighbor act independency and sovereignty upon another. (...)" Id. Ibid., p. 20-21.
} 
algum" assuntos bélicos poderão ser objeto de vingança e satisfação pessoal dos governantes dos estados soberanos.

Percebe-se claramente que William Penn fundamentou seu "projeto de paz" em uma imagem positiva do indivíduo e com isso na convicção de que uma pedagogia específica e autônoma, ou seja, pela educação se poderia garantir a renovação do homem e por conseguinte da humanidade, além dos fundamentos religiosos que permeiam todo o ensaio.

\subsection{Abbé de Saint-Pierre: "Projeto para tornar perpétua a paz na Europa"}

Segundo Truyol y Serra, o mais minucioso dos "projetos de paz perpétua" do período moderno, é indubitavelmente o do Abbé de Saint Pierre ${ }^{146}$, que acompanhou o Cardeal de Polignac no Congresso de Ultrech ${ }^{147}$.

Para a compreensão do pensamento de Saint-Pierre, devemos considerar que o autor faz parte da corrente pan-europeia da tradição do pensamento ocidental sobre a paz, a qual se agrega a maioria dos autores até agora estudados.

Todavia, o Abade se difere dos demais, por ser ele quem primeiro apresentou a ideia pan-europeia, de maneira sistêmica, como veremos no decorrer deste.

Com a intenção de apresentar à Europa de seu tempo ${ }^{148}$ uma verdadeira “Constituição Europeia", publicou no ano de 1713 impresso em três volumes seu "Projet

\footnotetext{
${ }^{146}$ Charles Irénée Castel de Saint-Pierre (1658-1743) - o Abade de Saint-Pierre - é o segundo dos cinco filhos de uma família da pequena nobreza da Baixa Normandia. Tendo perdido a mãe aos seis anos, $e$ inapto, por razões físicas, à formação militar, ele é conduzido a uma instrução eclesiástica onde descobre sua vocação: ele será um benfeitor da humanidade. Obcecado pelo interesse público - ou geral, como se mencionava na época - ele descobre que a política e as normas jurídicas são bem mais importantes do que a moral. Mas, sobretudo, ele convence-se de que as leis, e somente elas, poderão garantir a segurança e a paz. Essa constatação sustenta a elaboração do Projeto", in GOYARDFABRE, S., Projet pour rendre la paix perpétuelle em Europe (Introduction), Paris, Éditions Garnier Frères, 1981, p. 11, apud, SEITENFUS, Ricardo. Prefácio. In: SAINT-PIERRE, Abbé de. Projeto para tornar perpétua a paz na Europa, cit., p. XXIV.

${ }^{147}$ TRUYOL Y SERRA, Antonio. op. cit., p. 100.

148“Para o Abade, sua Europa contemporânea não estava configurada para evitar o clima de constantes guerras e para respeitar a execução dos acordos internacionais. Da mesma forma, o equilíbrio entre potências, como a França e a Áustria, era insuficiente para garantir a paz entre as nações europeias, bem como a paz interna em cada um desses países. Assim, para ele, as soberanias católicas - França, Inglaterra, Holanda, Portugal, Suíça, Florença, Gênova, Veneza, Dinamarca etc. - deveriam assinar um
} 
de traité pour la paix perpétuelle entre les souverains chrétiens ${ }^{149}$, , que foi resumido pelo próprio em 1728 em seu Abrégé du projet de paix perpétuelle ${ }^{150 ” . ~ I n f e l i z m e n t e ~}$ ambas versões do projeto passaram despercebidas à época.

De leitura difícil na versão original, verdade é que a obra de Saint-Pierre só obteve difusão graças ao comentário que dela fez Rousseau na publicação de 1761 de seu “Jugement sur la paix perpétuelle 151 ” que segue o “Extrait du projet de paix perpétuelle de M. l'abbé de Saint-Pierre ${ }^{152 " ~ p u b l i c a d o ~ e m ~ 1768, ~ a m b o s ~ r e d i g i d o s ~ p e l o ~ f i l o ́ s o f o ~}$ genebrino em 1758.

Fácil inferir ao longo da leitura do projeto em apreço, que o traço marcante da obra do Abade é a preocupação do religioso acerca da manutenção da política e da territorialidade da Europa ${ }^{153}$, propondo uma espécie "aliança entre os Estados soberanos cristãos" do velho continente.

Em sua obra, Saint-Pierre indica que a paz perpétua entre os Estados cristãos europeus somente será alcançada caso os soberanos venham a respeitar os princípios propostos em seu projeto.

Consoante a já aludida extensão da obra do Abbé de Saint-Pierre e a impossibilidade de realizar uma análise pormenorizada de todos os Discursos, Artigos e Objeções que integram o projeto.

Optamos por realizar um estudo agrupado no núcleo central da obra que de acordo com uma publicação de 1729, apresenta-se em cinco artigos fundamentais que não podem ser objeto de mudança.

Tratado de União e formalizar um Congresso Perpétuo. A vinculação dos soberanos católicos à sociedade europeia impediria o mau uso do poder, desestimulando iniciativas como a invasão de outros territórios ou o bloqueio ao comércio internacional", in SARFATI, Gilberto. Teorias de relações internacionais. São Paulo: Saraiva, 2005. p. 78.

${ }^{149}$ Nossa tradução: Projeto ou tratado para a paz perpétua entre governantes cristãos.

${ }^{150}$ Nossa tradução: Resumo do projeto de paz perpétua.

${ }^{151}$ Julgamento da paz perpétua.

${ }^{152}$ Extrato do projeto de paz perpétua do Abbé de Saint-Pierre.

153 “Pretextando economizar demoradas e complexas negociações entre os plenipotenciários das potências européias, o Abade, de fato, não esconde a sua pretensão: propor um texto acabado ao qual os soberanos somente expressariam a sua adesão, aportando pequenas modificações que lhes parecem indispensáveis. Portanto, o sistema proposto orienta-se pela racionalidade da ordem política, tanto interna quanto externa”. SEITENFUS, Ricardo. Prefácio, cit., p. XXXVIII. 
Ato contínuo, passemos à redação dos artigos fundamentais e uma sintética análise respectiva.

(1) A partir da conclusão do projeto, os signatários alcançariam uma aliança perpétua que propiciaria a eles e a seus sucessores uma absoluta e total segurança “contra as grandes desgraças das guerras estrangeiras e as grandes desgraças das guerras civis ${ }^{154,}$.

$\mathrm{O}$ autor propõe uma garantia mútua para proteger os Estados, seus bens e pessoas além de assegurar a completa herança de seu poder, ou seja, o respeito aos direitos hereditários.

Prescreve também que de forma gradativa, haveria uma substancial diminuição das despesas públicas em razão da economia com o armamento e, por conseguinte, um aumento efetivo da renda nacional.

O primeiro artigo fundamental reforça a ideia de que, como já falamos antes, a intenção do Abade é promover a manutenção do sistema de relação de poder entre os Estados da Europa.

(2) Os signatários contribuem individualmente, segundo suas possibilidades, para o financiamento dos custos coletivos da aliança ${ }^{155}$.

No tocante a repartição dos custos da aliança preconizada, segundo a proporcionalidade das riquezas de cada nação; o autor acredita que o financiamento da paz é preferencialmente de responsabilidade dos Estados soberanos mais ricos e desenvolvidos, porém, os países mais pobres devem participar desse financiamento de acordo com suas possibilidades.

\footnotetext{
${ }^{154}$ SEITENFUS, Ricardo. Prefácio, cit., p. xxviii.

${ }^{155}$ Id. Ibid., p. xxix.
} 
(3) Os signatários comprometem-se a não lançar mão de meios bélicos para resolver seus litígios presentes e futuros, e aceitam, em qualquer situação, a mediação e a arbitragem dos aliados ${ }^{156}$.

O segundo artigo demonstra a intenção de Saint-Pierre no sentido de resolver os conflitos entre os Estados europeus da mesma forma como seriam resolvidos os conflitos internos de cada Estado.

A mediação e arbitragem deveriam ser realizadas pelos pares, isto é, os Estados, no âmbito de uma Assembleia Geral. Essa forma de resolução de conflitos comporia o que o autor denomina de "Sistema de Paz", em contraposição ao "Sistema de Guerra". ${ }^{157}$.

A fim de expor as vantagens do sistema de resolução de conflitos entre os soberanos por meio da arbitragem sobre o sistema do uso da força (artigo fundamental que seguinte), o autor utiliza o conceito de dependência entre os Estados, com o seguinte exemplo: o soberano mais poderoso da Europa (o Rei da França segundo consta do projeto) está em relação de dependência diante dos outros soberanos tanto no sistema de força, quanto no sistema de paz.

Contudo, a grande diferença é que, no sistema de paz (arbitragem), o soberano é capaz de saber exatamente o que pode ser perdido se a decisão dos árbitros lhe for desfavorável; enquanto que no sistema de guerra (utilização da violência), se perder, o soberano não tem como medir as consequências para seu Estado ${ }^{158}$.

\footnotetext{
${ }^{156}$ SEITENFUS, Ricardo. Prefácio, cit., p. xxx.

157،No primeiro Discurso, mostrei que na atual constituição da Europa, isto é, no Sistema da Divisão e da Guerra, os Soberanos não possuem outra forma de decidir suas pretensões e de resolver suas controvérsias, senão pela destruição e aniquilamento de um ou outro dos Pretendentes; e que essas pretensões se repetiriam sempre, sem serem jamais efetivamente resolvidas. Isso, porque os Tratados não podem regulamentar claramente todas as pretensões futuras, e sem poder fazê-lo, os Soberanos não possuem até agora, qualquer garantia, qualquer seguranca suficiente do cumprimento desses Tratados.

"No Sistema da Paz, ao contrário, existe um meio seguro e eficaz de resolver sem Guerra todas as controvérsias: a arbitragem perpétua dos Soberanos da Europa continuamente representados por seus deputados reunidos em um congresso perpétuo, porque os árbitros assim unidos estarão suficientemente interessados em que seus julgamentos sejam cumpridos, e são suficientemente poderosos para realmente fazer com que o sejam, apesar da vontade e do poder daquele que deseje resistir." SAINT-PIERRE, Abbé de. op. cit., p. 112-113.

158“Se, todas as vezes que tomar as armas, o mais poderoso estiver suficientemente seguro de que o pior resultado do uso da força seria a perda dos recursos necessários para a Guerra, além dos danos sofridos por seus súditos, é possível não haver avaliado bem todas essas perdas e não havê-las comparado ao verdadeiro valor da pretensão que originou a Guerra, fosse desaconselhável correr o risco de inicia-la, No entanto, não poderá está seguro disso diante de seus inimigos, pois se estes tiverem suficiente
} 
Da mesma forma, o fato de o soberano poder confiar na arbitragem para resolver conflitos e conseguir mensurar a extensão de possíveis perdas advindas desse procedimento, reduziria o temor de ataque entre os soberanos e, consequentemente, geraria a diminuição de ataques recíprocos ${ }^{159}$.

Ainda em relação à segurança de cada soberano, entende que existe uma relação de igualdade de dependência de cada soberano em relação ao outro, na medida em que cada um está passível de ser julgado por todos os outros no caso da instauração de um julgamento ${ }^{160}$ arbitral.

(4) Todo e qualquer signatário da aliança que atentasse a sua solidez seria objeto de ações coletivas ${ }^{161}$.

Esse dispositivo prevê a aplicação de uma sanção aos Estados que não respeitarem as decisões oriundas dos referidos julgamentos e as soluções indicadas pela

\footnotetext{
superioridade na Guerra, nada os impedirá de conquistar um terço, a metade ou mesmo a totalidade de seu Estado, para ressarcir-se de perdas passadas (sic). Esse terrível inconveniente não existe no Sistema da arbitragem. O Soberano mais poderoso não perderá jamais nada além daquilo que for submetido a julgamento de seus árbitros. Suas despesas não serão grandes, suas fronteiras não serão atacadas, seu comércio não será interrompido e não haverá ressarcimento a fazer a seus inimigos. É preciso avaliar bem a importância desta vantagem." SAINT-PIERRE, Abbé de. op. cit., p. 114-115.

159،"As motivações mais fortes que podem levar os homens a causar mal a outrem são a cólera, o desejo de vingança, o receio de serem em breve surpreendidos e assassinados, a esperança de lucrar com os despojos de seu inimigo; são esses os mesmos motivos que levarão esses Chefes de família a causar esses grandes males uns aos outros, na medida em que se sintam ofendidos. (...) Ao contrário, se vivessem sob a proteção de uma arbitragem permanente, o ofendido teria diversos motivos a menos para temer seu inimigo. 1. Não recearia mais ser surpreendido e morto por ele, porque cada qual estaria seguro de que a Arbitragem condenaria o assassino à morte. 2. Não poderia esperar enriquecer-se com os despojos de seu inimigo. 3. O desejo de vingança seria até mesmo diminuído, porque estaria seguro de que a Arbitragem lhe proporcionaria ressarcimento sem que se colocasse em perigo ao reclamá-la (...)". Id. Ibid., p. 485-486.

${ }^{160 ، " M e s m o ~ q u e ~ s e ~ s u p o n h a ~ i g u a l d a d e ~ e n t r e ~ e s s a s ~ d u a s ~ e s p e ́ c i e s ~ d e ~ d e p e n d e ̂ n c i a, ~ e s s e ~ S o b e r a n o, ~ a o ~ a d o t a r ~}$ o Sistema da Paz, obtém tanto quanto cede. Afinal, ao ceder aos 23 outros Soberanos o direito e a liberdade de tomar armas contra eles quando desejar, com o objetivo de ressarcir-se, os demais também lhe estarão cedendo o direito e a liberdade que tinham de tomar armas contra ele, quando desejassem, a fim de obter justiça. Ao renunciar para sempre, no Tratado da União, a tomar contra eles o caminho da força, escolhendo a via da arbitragem para a resolver as controvérsias que ele e seus descendentes poderiam ter contra ele ou contra os futuros Chefes de sua Casa. Se ele lhes cede por esse Tratado o direito de serem árbitros perpétuos, direito que não possuíam, estarão estes também cedendo-lhe, por seu turno, o direito de ser árbitro perpétuo, direito que ele não possuía. Assim, qualquer que seja a superioridade que esse Soberano conceda aos demais Soberanos, ao estabelecê-los como árbitros perpétuos, esses outros Soberanos também estarão dando idêntica superioridade ao estabelecê-lo como árbitro perpétuo. A mesma dependência em que ele se coloca é também a dependência em que eles se colocam." Id. Ibid., p. 117.

${ }^{161}$ SEITENFUS, Ricardo. Prefácio, cit., p. xxii.
} 
aliança. Inclusive, de forma figurativa, Saint-Pierre compara os Estados às crianças, no sentido de que elas assim como os Estado, necessitam ter como perspectiva uma certeza de punição próxima que os impelem ao bom comportamento.

(5) Artigos suplementares poderiam adicionar-se aos atuais seguindo negociações diplomáticas realizadas pelos plenipotenciários dos Estados partes. Contudo, o seu alcance jamais poderia modificar o conteúdo destes cinco artigos fundamentais ${ }^{162}$.

Aqui o autor diz que a regulamentação dos artigos fundamentais é de competência dos Estados soberanos participantes da aliança. A complementação poderia inclusive ser feita por de leis internas (nacionais).

Interessante comentário sobre a obra de Saint-Pierre acerca da extensão dos efeitos do projeto para o mundo, nas palavras Gilberto Safarti:

"Outro elemento importante a ser observado é que o Abade acreditava
que a paz na Europa poderia ser expandida para o mundo, mas como?
A base do processo de integração europeia são os valores católicos
comuns das suas soberanias. Logo, se os valores católicos vencessem
os bárbaros, a expansão do catolicismo poderia significar o aumento
da área pacífica no mundo. Em outras palavras, o Abade expressa que
a base do processo de integração e pacificação são os valores comuns,
o que nos levaria contemporaneamente a discutir se os supostos
"valores europeus" são ameaçados pelo imigrantes das ex-colonias
europeias $163 . "$

\subsection{Jean-Jacques Rousseau: "Extrato e Julgamento do Projeto de Paz Perpétua de} Abbé de Saint-Pierre"

O propósito do presente é analisar o conceito de paz em Rousseau. Para tanto, é preciso ter presente três aspectos, a saber.

Primeiro, o contexto do século XVI e século XVII a partir de dois questionamentos centrais desta época: o crescimento da desigualdade entre os seres

\footnotetext{
${ }^{162}$ SEITENFUS, Ricardo. Prefácio, cit., p. xxii.

${ }^{163}$ SARFATI, Gilberto. op. cit., p. 79.
} 
humanos e a legitimidade do absolutismo político; segundo, a proposta de paz à Europa elaborada por Abbé de Saint-Pierre; terceiro, o projeto de paz articulado por Rousseau para a Europa.

Pode-se dizer que Jean-Jacques Rousseau ${ }^{164}$ é uma dos mais lidos e estudados filósofos modernos no ocidente por muitas razões.

A primeira, talvez seja a própria qualidade literária de seu texto, recheado de metáforas e comparações, que tornaram algumas de suas frases objeto de constantes citações, como por exemplo, "o homem nasce livre e, por toda parte, está preso em grilhões"165.

Todavia, cremos que a maior e significante razão é a abrangência e influência ${ }^{166}$ de suas reflexões na atualidade. E é justamente nesse diapasão, que inserimos as reflexões importantes e inovadoras de Rousseau acerca da guerra e da paz.

As ideias do autor sobre a paz devem ser entendidas em conexão com o marco maior de seu pensamento. Assim sendo, a construção de seus argumentos gerais sobre a vida social e o fenômeno da guerra encerra-se importante, haja vista que revela os

\footnotetext{
164“Jean-Jacques Rousseau nasce em Genebra em 1712 e morre em Ermenonville, na França, em 1778. Sua vida coincide, portanto, com o reinado de Luis XV e, com as primeiras fraturas sérias no absolutismo europeu, que culminam, na França, com o movimento revolucionário de 1789. O século XVIII assiste assim a um movimento de transformações na sociedade européia, mas transformações travadas, de um lado, pela prevalência de uma estrutura feudal e, de outro, pelo absolutismo. Como lembra Lecercle, "A ideologia de Rousseau foi formada em uma época pré-industrial, em uma França onde o desenvolvimento a burguesia ainda não havia apagado o seu caráter essencialmente camponês." A riqueza vem da agricultura e os mecanismos feudais obrigam os camponeses a reservar parte substancial da colheita para os direitos do senhor feudal e os impostos reais. Em meados do século, começa o processo de cercamento dos campos, já que o progresso da agricultura exige a formação das grandes propriedades. Lecercle observa que os senhores, com a cumplicidade do poder político, encontram pretextos para se apropriar dos bens comunais. "Os camponeses pobres, privados da possibilidade de pastar as suas vacas, protestam. O Estado Monárquico hesita, mas de modo geral favorece o interesse dos ricos contra os pobres. Em 1767, os decretos de cercamento de terras legalizam a prática, para grande prejuízo das comunidades camponesas. $\boldsymbol{O}$ progresso material é acompanhado assim de um progresso da desigualdade, e coube a Rousseau fundar a teoria desse processo dialético." Não é por acaso que seu primeiro grande trabalho é justamente Discours sur I'Origine et les Fondements de I'Inegalité parmi les bommes, que apresenta à Academia de Dijon em 1754", in: ROUSSEAU, Jean Jacques. Rousseau e as relações internacionais. Tradução: Sérgio Bath. Prefácio Gelson Fonseca Jr. São Paulo: Imprensa Oficial do Estado de São Paulo; Brasília: Ed. da UnB, 2003. p. XII-XIII. (Coleção Clássicos IPRI).

${ }^{165}$ Id. Ibid., p. IX.

${ }^{166}$ Sabe-se, por exemplo, que suas ideias tiveram grande influência no seu compatriota e filósofo Claude Henri de Rouvroy, o Conde de Saint-Simon assim como em Kant que dizia: “Eu teria que ler Rousseau até conseguir não me distrair mais pela beleza de sua expressão; somente então poderei examiná-lo com a razão". Citado por Ernst Cassirer, in Rousseau, Kant e Goethe. Nova York, Harper Torchbooks, 1963, p. 6. apud Id., loc. cit.
} 
próprios limites da capacidade humana de autotransformação e de conquista de liberdade $^{167}$.

De forma genérica, pode-se dizer que o ponto de partida da filosofia de Rousseau é a concepção de natureza humana representada pela famosa ideia segundo qual " $O$ homem nasce bom, a sociedade o corrompe", constante em sua obra "Contrato Social".

Verdade é, que os escritos rousseanianos sobre essa temática são poucos, fragmentados e quase desconhecidos pelos leitores do continente americano. Os mais conhecidos, são os seus comentários sobre o projeto de paz perpétua do Abbé de SaintPierre, que trataremos adiante, "Julgamento do projeto de paz perpétua do Abbé de SaintPierre" e o "extrato ${ }^{168 ", ~ d o ~ p r o j e t o ~ d o ~ r e l i g i o s o . ~}$

Deve-se ressalvar que Rousseau, no "Extrato" fez uma análise interpretativa do escrito de Saint-Pierre, e, em muitos aspectos, deformou as ideias originais do projeto; não o fez por mal o filósofo.

Ocorre que o Abade inspirou-se em um período distinto daquele vivido por Rousseau e, em sua reinterpretação da obra, Rousseau realizou uma verdadeira adaptação daquelas ideias ao seu próprio tempo, em suas palavras. "Assim, o livro de SaintPierre sobre Uma Paz Perpétua parece incapaz de fundá-la e desnecessário para mantê-la. "Trata-se portanto de um sonho vazio" - será o veredito do leitor impaciente. Mas, não: é uma obra de julgamento sólido, que tem para nós a maior importância ${ }^{169}$."

O fio condutor da crítica tecida ao texto de Saint-Pierre por Rousseau em seu "julgamento" consiste basicamente em quais seriam as condições necessárias para o estabelecimento da paz entre os Estados soberanos.

Para Rousseau diferentemente no que ocorria no projeto do abade, a questão do regime político interno era fundamental para estabelecer uma possibilidade de cooperação entre os estados. Essa visão pode ser exemplificada com o seguinte

\footnotetext{
${ }^{167}$ ROUSSEAU, Jean Jacques. Rousseau e as relações internacionais, cit., p. XI.

${ }^{168}$ Coube a Jean-Jacques Rousseau a tarefa de arrumar, selecionar e mandar editar os manuscritos do Abade de Saint-Pierre, falecido alguns anos antes no ano de 1743, quase nonagenário. Rousseau, filósofo consagrado na época, aceitou tal incumbência vislumbrando ser tarefa fácil. Assustou-se quando o sobrinho do Abade, o conde de Saint-Pierre, descarregou em seu escritório 23 volumes de manuscritos.

${ }^{169}$ ROUSSEAU, Jean Jacques. Extrato e julgamento do Projeto de Paz Perpétua de Abbé de Saint-Pierre. In: ___ Rousseau e as relações internacionais, cit., p. 101.
} 
questionamento: como um regime despótico poderia se unir a um regime democrático, mesmo que ambos tivessem o catolicismo em sua base ${ }^{170}$ ?

Nesse sentido, o texto de Rousseau, de acordo com Gelson Fonseca Jr., “embora partam da mesma perspectiva filosófica, há uma diferença de atitude entre o que propõe para a sociedade nacional e o que propõe para a sociedade internacional $^{171}$ ”.

Acreditava o filósofo, que a "confederação" preconizada por Saint-Pierre sempre seria imperfeita, ante a falta de coesão do povo nacional dentro dos próprios Estados, refletiria fora deles, na confederação.

Sua critica não para aí, pois Rousseau ataca a ideia de interdependência econômica como elemento pacificador, conforme apresentada por Saint-Pierre e resultará no aumento das tensões entre os países.

Assim, para Rousseau o equilíbrio de poder e a paz não são automáticos e deveriam ser trabalhados por meio da construção de sociedades ideais, ou seja, países pequenos e democráticos, à medida que esses países fossem soberanos em sua relação e legítimos intimamente.

Finalmente, ele sugere que a paz poderia ser possível pela formação de uma federação de Estados que seria soberano internamente, porem armados em conjunto contra as agressões externas e ligados pela economia, ou seja, federações do tipo da norte-americana ou dos cantões suíços.

Pois, de forma destacada no âmbito internacional Rousseau se mostra mais conformado em aceitar que a guerra marcará para sempre, a vida dos homens na sociedade dos Estados, enquanto que o equivalente não se opera na esfera de seu “contrato social” no âmbito nacional de cada Estado, individualmente.

Sendo assim, a inovação deste escrito é encontrada na passagem da vontade geral aquela que existe dentro de um Estado Soberano para uma vontade universal, ou seja, internacional.

\footnotetext{
${ }^{170}$ SARFATI, Gilberto. op. cit., p. 80.

${ }^{171}$ ROUSSEAU, Jean Jacques. Rousseau e as relações internacionais, cit., p. XI.
} 
“(...) podemos julgar o espírito com que os príncipes receberão provavelmente uma proposta que contraria um deles, e não parece mais favorável ao outro. Todos podem ver que a criação da assembleia da Europa determinará a constituição de cada Estado de forma tão inexorável quanto as suas fronteiras; que é impossível garantir o príncipe contra a rebelião dos seus súditos sem dar garantia a estes, ao mesmo tempo, contra a tirania do príncipe; e que, sem isso, a confederação não poderia se manter. Pergunto, assim, se haverá em todo o mundo um único soberano que, vendo-se desta forma limitado para sempre naquilo que mais preza, suportasse sem indignação a ideia de ver-se obrigado a ser justo não só com relação aos estrangeiros, mas até mesmo com seus próprios súditos ${ }^{172}$."

${ }^{172}$ ROUSSEAU, Jean Jacques. Extrato e julgamento do Projeto de Paz Perpétua de Abbé de Saint-Pierre, cit., p. 102. 


\section{CAPÍTULO 3. KANT E UM PROJETO FILOSÓFICO PARA A PAZ PERPÉTUA}

"Esta ideia racional de uma comunidade pacífica perpétua de todos os povos da Terra (mesmo quando não sejam amigos), entre os quais podem ser estabelecidas relações, não é um princípio filantrópico (moral), mas sim um princípio de direito”. (Kant)

Kant $^{173}$, ao longo de sua vasta e profícua produção filosófica empreendeu por tarefa ${ }^{174}$, a construção de um "edifício da filosofia" que pudesse oferecer possíveis soluções aos grandes questionamentos setorizados do conhecimento ${ }^{175}$.

Em uma alusão figurativa ao "edifício kantiano", temos que a obra Zum ewingen Frieden. Ein philosophischer entwurf ${ }^{176}$ representa o último andar de sua construção teórica, o que implica em uma abordagem preliminar dos conceitos fundamentais que serviram de alicerce para a estruturação desse edifício.

Em virtude da sistematicidade da obra kantiana, para analisarmos o projeto de paz perpétua de Kant e seus desdobramentos em determinadas searas da teoria e da

\footnotetext{
${ }^{173}$ Immanuel Kant nasceu em 1724, em uma cidade da Prússia Oriental denominada Königsberg. Filho de uma modesta e numerosa família de artesãos, recebeu de sua mãe educação segundo os princípios do pietismo, corrente radical do protestantismo prussiano. Estudou no Collegium Fridericianum, dirigido pelo pastor pietista F. A. Schultz. Entre 1740 e 1747, estudou na Universidade de sua cidade frequentando os cursos de ciência e filosofia. Durante os anos de 1747 e 1754 experimentou grandes dificuldades financeiras, tendo de trabalhar como preceptor, mas apesar das condições desfavoráveis, prosseguiu nos estudos, redundando na obtenção do título de doutor. Em seguida, conseguiu lecionar na Universidade de Königsberg como livre-docente em 1755. Naquela época, o professor, na categoria de livre-docente, recebia somente um valor correspondente ao número de horas de ensino e ao número de alunos que frequentava o curso. Mais tarde, em 1770, passou no concurso para professor ordinário com a dissertação "De mundi sensibilis atque intelligibilis forma et principiis"(Dissertação sobre as formas e os princípios do mundo sensível e do mundo inteligível). Uma das características mais marcantes do caráter moral deste autor, além de metódico e sistemático, foi sua aversão por carreirismo, renunciando qualquer forma de adulação. Kant se concentrava em sua pesquisa filosófica, de forma totalmente desinteressada em relação a qualquer possibilidade de fama ou riqueza. Segundo estudiosos de sua biografia, por volta de 1778 , chegou a receber um convite por parte do barão Von Zedlitz para assumir uma cátedra em Halle, o que lhe renderia um pagamento pelo menos três vezes maior do que o de Königsberg. Kant recusou tal oferta e com ela outra referente a um cargo público vinculado à mencionada cátedra.

${ }^{174}$ Ao analisarmos cronologicamente as obras de Kant, nota-se que com a chegada da maturidade do filósofo, que o texto kantiano não terá mais a preocupação excessiva em sua forma de apresentação ao leitor.

${ }^{175}$ Pode-se dizer que Kant envolveu-se com as grandes temáticas do conhecimento: espírito, ciência, moral e religião.

${ }^{176}$ Não há uma tradução uniforme para o opúsculo kantiano, sendo encontradas diversas variações para a tradução do alemão, dentre as quais podemos destacar: À Paz Perpétua, Para a Paz perpétua, Sobre a paz perpétua, Rumo à paz perpétua ou ainda Contribuições para o problema da paz.
} 
prática do direito internacional contemporâneo, que se encontra no próximo capítulo, faz-se necessário, mesmo que resumidamente, uma introdução geral ao pensamento do filósofo.

Nesse sentido, de antemão devemos assumir dois fios condutores do pensamento de Kant, tais como a concepção do homem como valor absoluto e dotado de dignidade e a necessidade da existência da liberdade para a efetivação da paz.

Assim, sob a ótica kantiana, o direito surge dentro dos limites da razão e da moral, para transformar-se em uma legislação universal, cujo fim será a paz perpétua.

A contribuição da moral para o desenvolvimento do direito, segundo Kant, reside no esforço que cada ser humano deve fazer para submeter a sua natureza às exigências do "dever ser", no sentido de que a chave para o fim de todos os conflitos está na consciência e, por conseguinte, no respeito dos indivíduos como seres portadores de dignidade.

Para o filósofo, é somente no domínio da moral que a razão poderá legitimamente manifestar-se em toda a sua plenitude, promovendo, no âmbito de seu pensamento concatenado, o futuro entendimento entre as nações e a paz mundial.

Demonstra o filósofo que seu projeto de paz não foi desenvolvido como uma quimera, como muitos autores costumam dizer. Ao contrário, Kant concebeu seu projeto como passível de execução, como o próprio asseverou neste trecho da Metafísica dos Costumes de 1797:

\footnotetext{
"Porque, que coisa há de ser mais metafisicamente sublime, se assim se pode dizer, do que essa mesma Ideia que, confessada por eles mesmos, alcança um valor objetivo inquestionável e inquestionado; Ideia que a experiência confirma e a única que, não ensaiada nem introduzida na prática pela violência das revoluções, isto é, pelo transtorno de uma constituição defeituosa (...) mas, ao contrário, realizada por meio de uma reforma lenta, insensivel e segundo princípios firmes, pode conduzir à paz perpétua, por meio de uma aproximação perpétua do soberano bem político!"177.
}

${ }^{177}$ KANT, Immanuel. Doutrina do direito, cit., p. 206-207. 
Na concepção de Kant, o estado de paz da humanidade só poderá ser alcançado apoiado em princípios racionais e morais firmes, mediante o cumprimento de três grandes etapas, sendo essas de natureza: pessoal, civil e cosmopolita.

Importante destacar que a paz perpétua de Kant não se funda na compaixão ou na caridade entre os indivíduos, mas sim em uma constante relação de direito. Direito esse intrínseco ao desenvolvimento de uma perspectiva racional da história da humanidade.

Kant confiou na possibilidade de um progresso histórico para melhor da humanidade $^{178}$, onde a liberdade seria conditio sine qua non para a paz perpétua, decorrendo dessa uma legislação universal com fundamento na razão pura, implantada como destino lógico da humanidade.

O questionamento assumido aqui por Kant para buscar uma possível solução é: O que posso esperar enquanto membro da sociedade humana? ${ }^{179} \mathrm{~A}$ resposta é a paz perpétua como a realização da justiça, nas nações e entre as nações.

É na paz perpétua que a humanidade atingirá sua moralidade mais perfeita pela eliminação da violência e, por conseguinte, obterá sua felicidade ante a ausência das guerras. Sendo assim, Kant considera a paz perpétua o único direito peremptório das nações.

O olhar de Kant sobre as grandes transformações de sua época, a visão do mundo por ele desenvolvida e sua utopia racionalista e ponderada ${ }^{180}$, constituem fonte de inspiração valiosa para o direito internacional contemporâneo ${ }^{181}$.

\footnotetext{
178 “Ora afirmo que posso predizer ao gênero humano, mesmo sem o espírito de um visionário, segundo os aspectos e os augúrios dos nossos dias, a consecução deste fim e, ao mesmo tempo, a sua progressão para o melhor e não mais de todo regressiva." KANT, Immanuel. Conflito das faculdades. Tradução: Arthur Mourão. Lisboa: Ed. 70, 1993. p. 105.

${ }^{179}$ SALGADO, Joaquim Carlos. Kant: revolução e reforma no caminho da Constituição Republicana: a paz perpétua. In: TRAVESSONI, Alexandre. Kant e o direito. Belo Horizonte: Mandamentos, 2009. p. 70.

${ }^{180}$ MELLO, Sérgio Vieira de. História filosófica e real: atualidade do pensamento político de Kant. In: MARCOVITCH, Jacques (Org.). Sérgio Vieira de Mello: pensamento e memória, cit., p. 36.

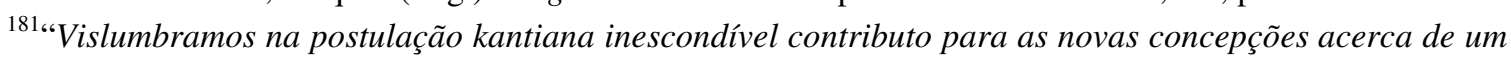
direito que tenha por finalidade a justiça social, posto que se impõem com o primado para de sua doutrina jurídica a noção de dignidade humana e um ideal de vida racional para a humanidade. Com isso, a filosofia do direito de Kant parece culminar em uma filosofia da história, porquanto uma república universal, condicãa da paz perpétua, não é apenas objetivo da doutrina do direito, mas o próprio devir de histórico da humanidade", in: LEITE, Flamarion Tavares. 10 lições sobre Kant. Petrópolis: Vozes, 2007. p. 127.
} 


\subsection{Breve introdução ao pensamento kantiano: critérios morais e racionais na investigação da paz}

Partindo-se de uma abordagem didática e objetiva com vistas ao encaminhamento do sistema kantiano para a paz perpétua, assumiremos uma ordenação temática de suas obras ${ }^{182}$, no intuito de traçar uma breve introdução geral do pensamento do filósofo.

Os escritos ${ }^{183}$ pré-críticos de Kant compreendem seus escritos da juventude e a sua produção oriunda da atividade docente na Universidade de Königsberg. Esse período é marcado por uma metafísica racionalista e pela grande influência de Leibniz e Newton. Destacamos o estudo História Universal da Natureza e Teoria do Céu (1755) e sua tese de titularidade para a cátedra de Lógica e Metafísica Dissertação sobre as formas e os princípios do mundo sensível e do mundo inteligível (1770), comumente citada como "Dissertação 1770".

Conforme os biógrafos de Kant afirmam, gradualmente o filósofo voltou o espírito da física para a metafísica transcendental, acordando de seu sono dogmático como o próprio disse na introdução de seus Prolegômenos a toda metafísica futura: "Confesso francamente: foi a advertência de David Hume que, há muitos anos, interrompeu o meu sono dogmático e deu às minhas investigações no campo da filosofia especulativa uma orientação inteiramente diversa ${ }^{184}$,.

Com a publicação da Crítica da Razão Pura (1781), assim como Copérnico, que para superar os impasses de uma crise da astronomia concebeu o modelo heliôcentrico, invertendo o geocentrismo, Kant inverte a questão tradicional da metafísica: em vez de procurar conhecer as coisas, é preciso examinar antes o próprio conhecimento e suas possibilidades.

\footnotetext{
${ }^{182}$ Importante consignar que as obras de Kant não serão citadas em conformidade com a edição da AKADEMIE.

${ }^{183}$ Neste período a temática kantiana resume-se basicamente ao estudo da física, lógica, matemática e ciências naturais.

${ }^{184}$ KANT, Immanuel. Prolegômenos a toda metafísica futura. Tradução: Arthur Morão. Lisboa: Edições 70, 2008. p. 17.
} 
O método utilizado pelo filósofo para desempenhar as investigações era a "crítica", ou seja, a análise reflexiva, na qual remonta-se o conhecimento às condições que o tornem legítimo.

Os "juízos" verdadeiros, isto é, necessários e universais, são, a priori, imperativos; in casu, categóricos. Um imperativo categórico, na linguagem kantiana, é aquele que independe da "sorte" da experiência. É particular e contingente.

Sobre o imperativo categórico Kant leciona:

"Da distinção entre o conhecimento teorético e o conhecimento
prático: “Conhecimentos práticos são:

1) Imperativos e, quanto tais, contraprõem-se aos conhecimentos teóricos; ou contêm:

2) os fundamentos para possíveis imperativos e, nessa medida, são opostos aos conhecimentos especulativos.

Por imperativo enteder-se-á, em geral, toda proposição que expressa uma ação livre possível, pela qual se deve alcançar realmente um certo fim. Por conseguinte, todo o conhecimento que contém imperativos é prático, e deve decerto chamar-se prático em oposição ao conhecimento teórico.

Mas este valor só é incondicionado, quando o fim a que se dirige o uso prático do conhecimento é um fim incondicionado. $O$ único fim incondicionado e derradeiro (fim último) a que, no fim de contas, se deve referir todo o uso prático do nosso conhecimento é a moralidade" ${ }^{185}$.

Ainda sobre o imperativo categórico e seus desdobramentos na Razão Prática, temos que Kant parte do pressuposto que o homem é provido de um dado a priori (uma forma a priori da razão prática) que, em última análise é um valor absoluto que não consegue negar a existência do dever, constituindo este, a priori, um imperativo categórico cuja fórmula é ${ }^{186}$ : “Age de tal modo que a máxima de tua vontade possa valer-

\footnotetext{
${ }^{185}$ KANT, Immanuel. Lógica. Tradução: Arthur Morão. Lisboa: Texto e Grafia, 2009. p. 86.

${ }^{186}$ LEITE, Flamarion Tavares. op. cit., p. 56.
} 
te sempre como princípio de uma legislação universal". ${ }^{187}$ Essa é a fórmula básica do imperativo categórico.

Derivam da formulação básica do imperativo categórico as fórmulas secundárias: "Age como se a máxima da tua ação se devesse tornar pela tua vontade em lei universal da natureza" e "Age de tal maneira que uses a humanidade, tanto na tua pessoa como na pessoa de qualquer outro, sempre e simultaneamente como fim e nunca simplesmente como meio".

Com base nas formulações, a básica e as secundárias, podemos perceber duas características acerca do imperativo categórico: a universalidade e o caráter de necessidade que ele impõe à ação.

Decorre de todas as formulações do imperativo categórico a apresentação do princípio da moral; então, conclui-se que, os imperativos categóricos são imperativos morais.

Entre 1784 e 1785, Kant publica uma série de escritos sobre a história, mas para nós cumpre citar Idéia de uma história universal de um ponto de vista cosmopolita (1785) e o Começo conjectural da história humana (1786).

\begin{abstract}
"Ideia de uma história universal a partir de um ponto de vista cosmopolita (1784), na qual Kant se propõe expressamente ver se possível descobrir no curso contraditório das coisas humanas "um desígnio da natureza, do qual se possa extrair, com seres que avançam sem um plano próprio uma historia que se desenvolva segundo um plano próprio natural determinado". A resposta de Kant é que o meio do qual a natureza se serve para operar o desenvolvimento de todas as disposições do homem é o antagonismo, por intermédio do qual o homem é induzido a desenvolver suas melhores qualidades e a passar, involuntariamente, da barbárie à civilização. Sem essa tendência ao isolamento, o homem teria permanecido pacifico dócil e servil como as ovelhas levadas ao pasto. "Graças sejam dadas então à natureza", exclama Kant, pela intratabilidade que gera, pela invejável emulação da vaidade, pela cobiça jamais satisfeita de haveres e também de dominio! Sem elas, todas as excelentes disposições naturais inseridas na humanidade permaneceriam o antagonismo desemboca sempre na luta cruenta; mas é certo que a luta cruenta é uma forma, ainda que extrema, de antagonismo. A distinção entre o sentimento profano e sentido arcano da história é expressa nitidamente nesta passagem: "O homem quer a concórdia; mas a natureza sabe melhor que ele o que é bom para a sua espécie: ela quer a discórdia”. E com maior força ainda: "O homem quer viver cômoda e pacificamente; mas a natureza quer que ele, saído do estado de preguiça e de satisfação inativa,
\end{abstract}

${ }^{187}$ KANT, Immanuel. Crítica da razão prática. Tradução: Paulo Barrera. São Paulo: Ícone, 2005. p. 32. 
enfrente dores e fadigas para inventar os meios de libertar-se também deles com a sua habilidade ${ }^{188, "}$.

A filosofia da história kantiana apresenta, resumidamente, implicações morais e políticas acerca de um conceito de história universal. Por meio desses escritos, identificamos o interesse de Kant em desenvolver de forma concatenada uma história da humanidade com base em fundamentos filosóficos, com vistas a contribuir para a história da civilização sob um aspecto novo: deveríamos pensar em uma história da humanidade de um ponto de vista universal e cosmopolita.

Sobre o escrito Começo conjectural da história humana (1786) tem por foco o passado do homem, para que possamos entender melhor o futuro desse mesmo homem. O fio condutor estabelecido por Kant são as primeiras páginas da Bíblia, e, ao estilo kantiano, essa narrativa das origens não é feita de forma dogmática, é submetida a uma reconstituição racional.

O trabalho no qual Kant se lança é o de mostrar como as fases da narrativa do Gênesis simbolizam etapas de evolução na história do homem: da tutela do estado de natureza para o estado de liberdade.

Ao final, sob a epígrafe "observação final”, Kant apresenta a condição histórica do homem com base na responsabilidade deste frente à felicidade, ao mal e ao progresso.

\begin{abstract}
"Este é o resultado de uma história humana primitiva, intentada com a ajuda da Filosofia: satisfação com a providência e com o curso geral das coisas humanas, que não transcorre do Bem para o Mal, mas que, pouco a pouco, se desenvolve do pior para o melhor. Para esse progresso cada um é chamado pela natureza a contribuir com a parte que lhe corresponda e segundo a medida de suas forças". 189
\end{abstract}

\footnotetext{
${ }^{188}$ BOBBIO, Norberto. O problema da guerra e as vias da paz. Tradução: Álvaro Lorencini. São Paulo: UNESP, 2002. p. 88.

${ }^{189}$ KANT, Immanuel. Começo conjectural da história humana. Tradução: Edmilson Menezes. São Paulo: UNESP, 2010. p. 39.
} 
O "estado de direito" à luz de uma interpretação kantiana do Direito, seria o estabelecimento pelo Estado de um "estado de coisas", onde cada um possa coexistir com os outros segundo uma lei universal de liberdade.

A confiança de Kant no regime do império da lei e não aos mandos e desmandos (caprichos) dos governantes, como disse Norberto Bobbio um dos melhores intérpretes do autor, ele confiava no governo das leis e não no governo dos homens.

Kant revela um otimismo quanto ao progresso da humanidade, todavia, sempre através de reformas implantadas por um governante, contidas nas leis emanadas de um Legislativo escolhido entre os melhores da população.

Importante ressaltar que o pensamento político filosófico de Immanuel Kant apresenta o Direito como a condição de existência das liberdades dos indivíduos isolados.

O desenvolvimento destas liberdades individuais dar-se-ia no âmbito de um sistema jurídico. Esta é a condição fundamental para o progresso da humanidade, motivo pelo qual, para Kant, o Direito ocupa um lugar central na História.

Por fim, as três principais obras de Kant sobre questões éticas, que para ele pertencem à outra dimensão de nossa racionalidade, a razão pratica e não à razão teórica, são: Fundamentação da metafísica dos costumes (1785), Crítica da razão prática (1788), que tratam da ética no sentido puro, e Metafísica dos costumes (1787), que consiste numa tentativa de aplicação dos princípios éticos.

\subsection{Apresentação da estrutura do projeto}

O projeto de Kant, para os fins deste estudo, foi dividido em quatro partes que seguem.

Primeira Parte: os artigos preliminares, onde o filósofo define o verdadeiro artigo de paz, concede a todos os Estados, independentemente do seu tamanho ou importância, o direito ilimitado de existência, exige a redução sucessiva das tropas e

proíbe realizar dívidas quanto às relações externas, assim como intervenções violentas à constituição e ao governo de outros Estados e, finalmente, prescreve que 
a hostilidade durante uma guerra que impossibilite um futuro acordo de paz deve ser evitada a todo custo.

Segunda Parte: seguem os artigos definitivos, ou seja, os núcleos imutáveis sem os quais em hipótese alguma se poderia alcançar a paz desejada por Kant. Adverte-se que a análise do terceiro artigo definitivo do projeto encontra-se no próximo capítulo, ante a relevância desse artigo para o direito internacional contemporâneo.

Terceira Parte: Ao estudo dos artigos seguem a exposição acerca da garantia e do artigo secreto para uma paz perpétua futura e a discussão sobre a moral e a política nos apensos.

Tal qual fizemos no capítulo anterior, no caso dos artigos tanto nos preliminares como nos definitivos, há a transcrição do texto original e, abaixo, sua análise respectiva.

Todavia, o próprio título da obra merece uma atenção especial, o que faremos agora.

Kant teria retirado o nome "pax perpetua" de uma inscrição satírica de uma tabuleta pendurada em uma pousada holandesa, debaixo de uma pintura que representava um cemitério.

\begin{abstract}
“...estaria dedicada aos "homens" em geral, ou especialmente aos governantes, nunca fartos de guerra, ou talvez somente aos filósofos, envoltos na fruição do doce sonho de paz?"190
\end{abstract}

Para alguns, somente no cemitério a humanidade alcançaria a paz perpétua.

Contudo, outra análise possível acerca do título do opúsculo kantiano seria por meio da própria construção linguística utilizada pelo autor em “À Paz Perpétua”. O adjetivo em questão não possui uma função sintática acessória na nomenclatura de seu projeto, ele é, em verdade, um elemento imprescindível deste ${ }^{191}$. Desta feita, o adjetivo

\footnotetext{
${ }^{190}$ KANT, Immanuel. Rumo à paz perpétua, cit., p. 19.

${ }^{191}$ ROHDEN, Valério (Org). Kant e a instituição da paz. Porto Alegre: Ed. da Universidade, 1997. p. 13.
} 
"perpétuo" determina os próprios conceitos da investigação que o filósofo se propõe a fazer do tema paz.

\subsubsection{Análise dos artigos preliminares}

ARTIGO 1: Nenhum tratado de paz deve valer como tal, se foi concluído reservando-se tacitamente matéria para uma guerra futura

Devemos inferir deste artigo que um tratado internacional nunca deve ser interpretado como um simples armistício, ou seja, como um mero adiamento das hostilidades.

Quanto às reservas, no sentido contemporâneo do termo (direito dos tratados) Kant veda expressamente a utilização do instituto jurídico, vez que, quando feitas, geralmente são imbuídas de má-fé, sendo utilizadas na primeira oportunidade favorável ao Estado que a impôs.

ARTIGO 2: Nenhum Estado existente por si (grande ou pequeno, tanto faz) poderá ser adquirido por outro Estado por herança, troca, compra ou doação.

Aqui temos bem clara a ideia de soberania. Para o filósofo, um Estado não é um patrimônio privado. Destarte, não poderá o Estado (personalidade jurídica pública) ser herdado, trocado, comprado ou doado.

Importante destacar que Kant assevera que a soberania conferida ao Estado propicia o direito de comando (governo) e disposição de seu território.

ARTIGO 3: Exércitos permanentes (miles perpetuus) devem ser inteiramente suprimidos com o tempo.

Em favor da abolição dos exércitos permanentes, Bobbio destaca que Kant aventa razões de ordem utilitária e moral. 
Entre as primeiras deve ser considerada a despesa excessiva com a manutenção militar, que por vezes, pode inclusive induzir um Estado à guerra. Quanto à segunda razão, de ordem moral, é o fato do soldado de um exército nacional permanente acabar se tornando um mero instrumento de fins e, portanto, acaba sendo degradado na sua própria dignidade pessoal ${ }^{192}$ :

ARTIGO 4: Não se podem contrair dívidas públicas tendo em vista conflitos externos do Estado.

Os exércitos deveriam ser abolidos por um motivo bem óbvio: de forma tácita eles incitam a guerra, vez que estão sempre preparados para um ato beligerante.

Ademais, na visão kantiana, o uso de pessoas como meras máquinas (leia-se soldados) ou ferramentas na mão do Estado Soberano não se coaduna com o direito da humanidade como pessoa em si mesma.

A interpretação se dá da seguinte forma: o Estado pode fazer "empréstimos" (obter ajuda) fora ou dentro de suas fronteiras em favor de sua economia interna, como por exemplo melhorar suas estradas, saneamento básico etc.

Contudo, não deve o Estado fazer dívidas exorbitantes, pois a bancarrota de um país pode propiciar o enfraquecimento do mesmo e o perigo iminente da guerra. Afinal, outros Estados podem aproveitar-se da situação desfavorável.

\section{ARTIGO 5: Nenhum Estado deve intervir pela força na constituição e no governo de outro Estado.}

Nenhum instituto moral, político e jurídico pode autorizar um Estado a intrometer-se na soberania de outro Estado.

\footnotetext{
${ }^{192}$ BOBBIO, Norberto. Direito e Estado no pensamento de Immanuel Kant. Tradução: Alfredo Fait. Brasília: Ed. da UnB, 1984. p. 256.
} 
Toda e qualquer forma de interferência em assuntos internos de um país é extremamente condenável pelo Direito Internacional.

\begin{abstract}
"Aqui Kant somente repete o principio, consagrado no direito internacional, da não intervenção, segundo o qual nenhum Estado pode intervir nos negócios internos ou externos de um outro Estado a não ser que isso seja previsto num tratado que vincule os dois. Existe um caso em que Kant admite o direito de intervenção, e é aquele no qual um Estado foi dilacerado por uma guerra civil: mas, nesse caso, ele comenta, a situação que se criou foi de anarquia não é mais um Estado, pelo contrário, é a ausência de qualquer forma de Estado ${ }^{193}$ ".
\end{abstract}

ARTIGO 6 - Nenhum Estado, em guerra com outro, deve permitir hostilidades de tal natureza que tornem impossível a confiança recíproca na paz futura: como a utilização de assassinatos, de envenenamentos, da violação de uma capitulação e do incitamento à traição no Estado com o qual se está em guerra.

Para Kant, todos estes estratagemas arrolados no artigo supracitado são desonrosos; mais especificadamente, imorais.

“(...) alguma confiança no modo de pensar do inimigo deve remanescer mesmo em meio à guerra, pois, do contrário, nenhuma paz poderia ser concluída, e as hostilidades resultariam numa guerra de extermínio (bellum internecinum); a guerra é por certo apenas o triste meio necessário no estado de natureza (em que não há nenhum tribunal que poderia julgar com força do direito), para afirmar pela violência o seu direito;em que nenhuma das duas partes pode ser declarada inimigo injusto ( porque isto já pressupõe uma sentença jurídica); porém, é o seu desenlace (como num dos assim chamados juizos de Deus) que decide de que lado se encontra o direito; entre os Estados, todavia, não é dado conceber qualquer guerra de punição (bellum punitivum) (porquanto entre eles não se verifica nenhuma relação de um superior com um subordinado).",194

Entre esses atos Kant cita o recurso a assassinos, envenenadores, espiões, ruptura de uma capitulação e instigação à traição.

\footnotetext{
${ }^{193}$ BOBBIO, Norberto. Direito e Estado no pensamento de Immanuel Kant, cit., p. 257.

${ }^{194}$ KANT, Immanuel apud GUINSBURG, J. (Org.). A paz perpétua: um projeto para hoje. Tradução: J. Guinsburg. São Paulo: Perspectiva, 2004. p. 36.
} 
Pode ser acrescentado que o uso de meios desonestos transformaria qualquer guerra em guerra de extermínio (Bellum Internecinum), que é uma forma ilícita de guerra. Além de guerra de extermínio, Kant considera ilícita a guerra de punição, porque é possível somente entre um superior e um inferior, uma vez que todos os estados são iguais entre si; e a guerra de conquista, porque a liberdade de um povo tem como efeito o aniquilamento moral do Estado.

\subsubsection{Análise dos artigos definitivos}

Antes de proceder à análise dos artigos definitivos do projeto kantiano, cabe ressalvar, mais uma vez, que a análise do terceiro artigo definitivo terá lugar no próximo capítulo, de forma apartada.

\section{1) A Constituição Civil em cada Estado deve ser republicana.}

Em sua ótica, uma Constituição Civil (republicana) é conditio sine qua non para o êxito do resultado tão desejado de seu projeto, qual seja; a paz.

Cabe ao próprio filósofo explicar os motivos de seu convencimento nos dois trechos abaixo, extraídos de obras distintas:

"Em uma Constituição republicana é inevitável o consentimento dos cidadãos para se decidir sobre a declaração de uma guerra, e é muito natural que eles tenham grande hesitação em embarcar em tão perigosa empresa. Tal decisão significaria trazer para si todas as misérias da guerra...Em uma Constituição na qual o assunto não é da alçada dos cidadãos, e por isso não é republicana, entrar em guerra é a coisa mais simples do mundo." 195

“(...) não se trata de saber se a paz perpétua é possível na realidade ou não, nem se nos enganamos em nosso juízo prático quando opinamos pela afirmativa, mas sim que devemos proceder como se este suposto, que talvez não se realizará, devesse, no entanto, realizar-se(...) e tratar de estabelecer entre nós, dando a constituição( talvez o republicanismo

${ }^{195}$ KANT, Immanuel apud NOUR, Soraya. op. cit., Prefácio, p. XVI. 
de todos os Estados em conjunto e em particular) que nos pareça mais própria para alcançar esse fim e pôr termo à guerra execrável, "196

\section{2) O Direito das Gentes deve ser fundado sobre um federalismo de Estados livres.}

Antes de redigir o “À paz perpétua”, Kant, em suas análises, já vislumbrava que a "razão prática" dos homens forçaria os Estados a abandonarem o "estado natural" que provoca as guerras.

E assim sendo, os Estados Soberanos, então, seriam impelidos a fundar uma ordem legal internacional com o objetivo de evitar guerras.

Segundo Kant, o estado de paz da humanidade é alcançado por duas grandes etapas: a primeira é a saída dos indivíduos do estado de natureza e a constituição dos Estados modernos. A segunda é a saída dos Estados do estado de natureza e a constituição de uma sociedade jurídica universal.

Em seus dizeres:

"Todo Estado pode e deve afirmar a sua própria estabilidade, sugerindo aos demais para que formem com ele uma espécie de constituição, semelhante à constituição política, que garanta o direito de cada um. Isto seria uma Sociedade de nações, à qual, contudo, não deverá ser um Estado de nações ${ }^{197 ", .}$

\subsubsection{A garantia e o artigo secreto para uma paz perpétua futura}

Nos dois apensos ao projeto de paz perpétua kantiano, o autor, de uma forma genérica, expõe uma relevante faceta de seu projeto: a relação entre o intelectual e o poder.

Nesse sentido, o autor explicita que imperiosamente deveria ser estabelecido um canal de comunicação entre os intelectuais e os governantes das nações.

\footnotetext{
${ }^{196}$ KANT, Immanuel. Doutrina do direito, cit., p. 205-206.

${ }^{197}$ Id. Rumo à paz perpétua. Tradução: Heloísa Sarzana Pugliesi. Edição Bilingüe. São Paulo: Ícone Ed., 2010. p. 49.
} 
E com fito nessa faceta revelada, apresentaremos sucintamente e por vezes em forma de tópicos, as ideias centrais dos suplementos.

\section{PRIMEIRO SUPLEMENTO: Da garantia da Paz Perpétua}

(1) Eis as disposições provisórias da natureza:

Primeira: cuidou ela que os homens possam viver em todas as partes do mundo.

Segunda: distribuiu-os, por meio da guerra, em todas as regiões, mesmo nas mais inóspitas, para que as povoem e habitem.

Terceira: por meio da própria guerra, obrigou os homens a entrar em relações mútuas mais ou menos legais.

(2) A natureza utiliza a guerra como um meio para povoar inteiramente a terra. A guerra, por sua vez, não necessita de motivos e impulsos especiais, pois parece enxertada no ânimo e entusiasma para a honra, sem necessidade de interesse egoísta que o movam.

(3) A constituição republicana é a única perfeitamente adequada ao direito dos homens; mas é muito difícil de estabelecer, porém, mais ainda de se conservar.

(4) A ideia do direito das gentes pressupõe a separação de numerosos Estados vizinhos, independentes uns dos outros. Esta situação é por si mesma bélica, a não ser que haja entre as nações uma união federativa que impeça a ruptura das hostilidades.

(5) Desse modo, a natureza garante a paz perpétua, utilizando em seu proveito o mecanismo das inclinações humanas. Imediatamente, resulta que essa garantia não é suficiente para poder vaticinar com segurança teórica o futuro; mas no sentido prático, moral, é suficiente para obrigar-nos a trabalhar coletivamente para conseguir esse fim, que não é mera ilusão. 


\title{
SEGUNDO SUPLEMENTO: Artigo secreto para a Paz Perpétua
}

O único e secreto artigo para a paz perpétua está incluso na seguinte proposição: As máximas dos filósofos sobre as condições da possibilidade da paz pública devem ser sempre levadas em contra e estudadas pelos Estados passíveis de um estado latente de guerra.

\subsubsection{A discussão sobre a moral e a política na paz: os apensos}

\section{APENSO 1: Sobre o desacordo entre a Moral e a Política quanto à Paz Perpétua}

Segue em destaque que bem consubstancia o conteúdo do apenso acima em epígrafe.

\begin{abstract}
"A politica diz: 'Sede prudentes como as serpentes'; a moral the acrescenta (como condição restritiva): 'e sem falsidade como as pombas'. Se ambas não podem coexistir em um mandamento, então há realmente um conflito entre a política e a moral; mas se ambas devem estar inteiramente unidas, então é absurdo o conceito do contrário, e nem sequer pode-se colocar como tarefa a questão de como ajustar semelhante conflito. Embora a sentença, "a honradez é a melhor política", contenha uma teoria que a prática infelizmente(!) contradiz muitas vezes, a sentença igualmente teórica, a honradez é melhor do que toda a política, está infinitamente acima de toda objeção, e é mesmo a condição ineludivel da política. $O$ deus Termo da moral não retrocede diante de Júpiter (o deus Termo do poder); pois encontra-se submetido ao destino, isto é, a razão não se acha bastante iluminada para abarcar a série de causas predeterminantes que permite predizer com certeza o resultado feliz ou infeliz das ações ou omissões dos homens segundo o mecanismo da natureza (ainda que permitam aguardá-lo conforme os nossos votos).,"198
\end{abstract}

\section{APÊEDICE 2: Da unanimidade da Política com a Moral segundo a noção transcendental do Direito Público}

Aqui o filósofo disserta acerca da importância de um "pacto internacional" concebido em consonância com a ideia de um contrato social primitivo.

${ }^{198}$ KANT, Immanuel apud GUINSBURG, J. (Org.). op. cit., p. 67. 
No alcance do espectro desse pacto internacional, os países teriam que se comprometerem no sentido de não intromissão nas discórdias internas das outras nações. Em contrapartida, garantiriam para si uma defesa recíproca em caso de ataques dos inimigos estrangeiros.

Garantindo para si, garantindo ao mesmo tempo defesa recíproca Kant concatena de forma ternária esse apêndice com apoio nas seguintes.

- direito público (jus civitatis);

- direito das gentes e;

- direito cosmopolita. 


\title{
CAPÍtulo 4. O PROJETO DE PAZ DE KANT E O DIREITO INTERNACIONAL CONTEMPORÂNEO
}

\begin{abstract}
"Se é um dever, e ao mesmo tempo uma esperança, contribuirmos todos para realizar um estado de direito público universal, mesmo que seja só em aproximação progressiva, a ideia da "paz perpétua", que se deduz dos até hoje falsamente chamamos tratados de paz - na realidade, armistícios -, não é uma vã fantasia, mas um problema que vai resolvendo poисо a pouco, aproximando-nos prontamente do fim almejado, já que o movimento do progresso há de ser, no futuro, mais rápido e eficaz do que no passado". (Kant - Parágrafo final de "À paz perpétua")
\end{abstract}

Discorrer sobre a atualidade e a importância do projeto de paz perpétua de Kant para o direito internacional contemporâneo não se encerra missão fácil, pois em uma atenta leitura do opúsculo kantiano se pode perceber muitos aspectos atuais para o direito internacional, sendo impossível para o espectro do trabalho realizar uma análise exauriente e detalhada.

Assim o que se propõe aqui realizar é introduzir o tema que nomeia o capítulo, de forma genérica mais à título de apresentação, alguns pontos de contato inferidos do projeto de paz perpétua kantiano com o direito internacional contemporâneo.

Diante do exposto seguem duas análises contrapostas quanto à estrutura e conteúdo de pesquisa, como se verá.

\subsection{Alguns apontamentos atuais sobre a influência dos elementos kantianos no direito internacional}

Seguem em tópicos e por enunciados temáticos seis aspectos atuais para o direito internacional contemporâneo que pode ser facilmente deduzido da leitura do projeto de Kant, ou ainda de sua teoria de paz, por meio de alguns elementos reconhecidamente kantianos, quais sejam:

1- a guerra sob a perspectiva de um assunto de interesse universal, não apenas dos Estados diretamente envolvidos; 
2- A ideia de unidade da humanidade, no qual a paz se insere como condição de vida harmônica e se torna um imperativo categórico;

3- A substituição da violência pelo "império do direito";

4- A autodeterminação social e política dos povos constante dos tratados das Organizações Internacionais contemporâneas;

5- A Constituição republicana de Kant que se identifica com a concepção contemporânea de democracia representativa e participativa e por fim;

6- A livre circulação de informações, de pessoas e de mercadorias.

Em Kant, a ideia de uma paz perpétua só é fantasiosa se for imaginada sua concretização imediata, pois a perpetuidade relaciona-se com a progressiva universalização dos meios pacíficos, mediante a aproximação dos povos e Estados.

Nesse exato sentido preleciona Casella:

"O conceito de I. KANT, no ensaio a respeito da ideia de história universal de ponto de vista cosmopolita (1784), corresponde ao ideal de racionalização da ordenação internacional: tem consciência de que o mundo não é estado de direito, mas tem de estar dotado de princípios e normas, e o conjunto de instituições internacionais pode ser aperfeiçoado. (...) Dentre os ideais cosmopolitas, a busca da paz como base de ordenação da convivência, entre as unidades do sistema internacional, faz (...) A crítica kantiana aos predecessores teóricos na busca da paz perpétua não se dá quanto ao objeto, mas quanto a crer que esse ideal possa breve e facilmente ser implementado ${ }^{199}$ ".

Ainda nesse sentido, podemos verificar a inspiração kantiana presente na Carta das Nações Unidas. Uma leitura mais atenta da Carta permite constatar que alguns artigos refletem algumas premissas indicadas no projeto de paz perpétua do filósofo alemão.

Um ótimo exemplo é a dicção do artigo segundo da Carta da ONU, em destaque: ${ }^{199}$ ACCIOLY, Hildebrando; SILVA, Geraldo Eulálio do Nascimento e; CASELLA, Paulo Borba. op. cit.,
p. 47. 
"Nenhum dispositivo da presente Carta autorizará as Nações Unidas a intervirem em assuntos que dependam essencialmente da jurisdição de qualquer Estado ou obrigará os membros a submeterem tais assuntos a uma solução, nos termos da presente Carta (...)”.

E o Quinto artigo preliminar kantiano: "Nenhum Estado deve intervir pela força na constituição e no governo de outro Estado”.

Não poderíamos deixar de citar outros documentos internacionais que possuem clara inspiração nos projetos de paz perpétua citados no trabalho, tais como: Convenção de Viena sobre relações diplomáticas, Declaração americana dos direitos e deveres do homem, Declaração Universal dos Direitos do Homem, Protocolo de Genebra e Protocolo de renúncia à guerra (Pacto Briand-Kellog).

\subsection{O direito cosmopolita kantiano: um estudo do terceiro artigo definitivo e sua influência no direito internacional contemporâneo}

Conforme asseverado previamente no capítulo anterior, tem lugar agora, o estudo do terceiro artigo definitivo do projeto kantiano. Importante salientar que o presente estudo destacado da análise dos demais artigos definitivos, teve por fundamento a leitura da análise realizada na tese de doutoramento de Soraya Nour ${ }^{200}$. Claro que o estudo que aqui pretende se encetar possui uma menor abrangência do que a realizada pela autora paradigma.

O enunciado do artigo em apreço é: o Direito Cosmopolita deve restringir-se às condições da hospitalidade universal.

Saliente-se que em diferentes obras e traduções por vezes o "direito cosmopolita" aparece como "direito cosmopolítico". Pesquisando sobre a diferença final dos termos, nota-se que quando o tradutor quer acentuar sua característica estatal, utiliza a segunda opção.

\footnotetext{
${ }^{200}$ NOUR, Soraya. O conceito de direito internacional em Kant e sua recepção na filosofia política do direito internacional e das relações internacionais. 1999. Tese (Doutorado) - Faculdade de direito da Universidade de São Paulo, São Paulo, 1999.
} 
Nesse sentido, não obstante a pequena diferença entre as duas formas, para os fins deste trabalho como um todo, ambas as designações ensejarão sempre o mesmo sentido.

O direito cosmopolita é estabelecido a partir do princípio de que todos, originariamente, têm o mesmo direito sobre o solo e, assim, ninguém tem mais direito que um outro indivíduo de estar em um determinado lugar do planeta Terra. Segundo Kant, a condição para a sua efetivação requer uma época da história em que a violação do direito ocorrida num ponto da Terra seja sentida em todos os demais pontos da Terra $^{201}$.

É o direito que um estrangeiro tem de entrar em um outro país (outro Estado que não seja o seu) e não ser tratado com hostilidade. O nacional do outro território pode até não querer recebê-lo, mas enquanto o estrangeiro comportar-se de maneira amistosa, aquele não deve tratá-lo de modo hostil.

Muitos acreditam e tratam, inadvertidamente, o direito cosmopolítico como uma espécie de "direito de visita". Todavia, o filósofo advertiu, de forma expressa em seu texto, não se tratar de filantropia, e sim de direito e hospitalidade.

Ainda acerca do tema no direito internacional contemporâneo, Luciano José Trindade, em seus dizeres, ensina que:

“A concepção de Kant sobre o direito cosmopolita é até hoje
fundamental para a análise e discussão sobre uma politíca universal de
direitos humanos e a possibilidade de compatibilizar os princípios
jurídicos do não intervencionismo e da intervenção humanitária. É
justamente a sensibilidade em relação á violação dos direitos, presente
na época histórica da criação da ONU, que leva à Declaração
Universal. Esta é uma expressão do potencial do jus cosmopoliticum,
de um direito novo, atento no plano internacional à relevância
axiológica de se respeitar a dignidade da pessoa humana ${ }^{202 " . ~}$

Optamos por encerrar a análise do referido artigo por meio das três digressões, abaixo em destaque, retiradas da Doutrina do Direito, primeira parte da Metafísica dos Costumes, de 1797, ou seja, obra do autor posterior e sequente ao seu

\footnotetext{
${ }^{201}$ TRINDADE, Luciano José. À Paz perpétua de Kant e a sociedade internacional contemporânea. Ijuí: Unijuí, 2010. (Coleção relações internacionais e globalização).

${ }^{202}$ Id. Ibid., p. 300-302.
} 
projeto de paz perpétua, no intuito de fomentar mais digressões acerca do Direito Cosmopolita na atualidade.

"A natureza encerrou todos os homens juntos, por meio da forma redonda que deu ao seu domicílio comum (globus terraqueus), num espaço determinado" ${ }^{, 203}$.

“(...) que a violência e os males sofridos num ponto de nosso globo se propaguem por todo o globo. Contudo, este inconveniente possível não pode privar do direito cosmopolítico de ensaiar a sociedade com todos e de percorrer com esse intento todos os países da Terra, ainda quando não haja direito de se estabelecer (jus incolatus) no território de outra nação a não ser por meio de um contrato particular(...),204.

"Este direito, como a união possível de todos os povos, com relação a certas leis universais de seu comércio possível, pode ser chamado de direito cosmopolítico (jus cosmopoliticum), ${ }^{, 205}$.

\footnotetext{
${ }^{203}$ KANT, Immanuel. Doutrina do direito, cit., p. 201.

${ }^{204}$ Id. Ibid., p. 202.

${ }^{205}$ Id., loc. cit.
} 


\title{
CAPÍtUlO 5. A BUSCA dA PAZ PERPÉtUA NA ATUALIDADE: AS ORGANIZAÇÕES INTERNACIONAIS
}

\begin{abstract}
"A construção de um sistema internacional em que a Política e a Ética deixem de ser esferas independentes, passando ao contrário, a se interpenetrarem cada vez mais nas linhas do ideal kantiano de uma razão abrangente do ponto de vista da humanidade". (Celso Lafer)
\end{abstract}

Aquilo que o Abade de Saint-Pierre e Kant nomearam de "paz perpétua" na modernidade tornou-se, no século XX, muito mais que um ideal: tornou-se, em verdade um bem a ser almejado por todos os povos; um bem que toda humanidade deveria sempre tutelar,: ou seja, "a paz"206.

Chegando a este ponto do trabalho, se percebe inútil procurar no ensaio de paz de Kant, ao menos uma alusão à estrutura exata da federação dos povos, ou ao conteúdo preciso da aliança permanente e pacífica que, supostamente, deveria reuni-los. Assim ocorre porque o autor coloca essa estrutura no plano dos princípios.

No entanto, são esses princípios e, sem sombra de dúvida, o segundo artigo definitivo aqui analisado, que inspiram os redatores do Pacto da Sociedade das Nações e, mais tarde, os da Carta das Nações Unidas.

Nesse sentido, Kant é o pai espiritual do tipo de aliança pacífica pelo qual os Estados na atualidade parecem ter optado.

Em síntese, o direito internacional contemporâneo caracteriza-se pela consolidação de um sistema de Estados nacionais destinados a abraçar todo o globo terrestre, em correlação com o direito anunciado cosmopolítico kantiano.

Inicialmente, com a experiência da "Liga das Nações Unidas" e em seguida com a "Organização das Nações Unidas", buscou-se um novo modelo universal de estruturação político-jurídica.

\footnotetext{
${ }^{206}$ TEIXEIRA, Anderson Vichinkeski. Teoria pluriversalista do direito internacional. São Paulo: VMF Martins Fontes, 2011. p. XVI.
} 
A inspiração kantiana se tornou flagrante na própria Carta das Nações Unidas, ao consagrar tácita e expressamente "a paz perpétua" como um ideal a ser buscado por todas as nações.

\begin{abstract}
"A ideia de um funcionalismo público internacional independente da influência dos Estados membros, que a Carta da ONU consagrou, não constava do Pacto da Sociedade das Nações. Entretanto, o antecedente do art. 100 foi o art. $1^{o}$ do Regulamento do Pessoal da Liga das Nações, que também previa o caráter exclusivamente internacional do secretariado da primeira organização internacional de vocação universal que surgiu no primeiro pós-guerra. As idéias de Kant inspiraram a criação da Liga das Nações, e Sérgio menciona em seu texto que o Projeto de Paz Perpétua era livro de cabeceira de Woodrow Wilson, o grande artífice da liga $a^{207}$,.
\end{abstract}

\title{
5.1. O direito internacional contemporâneo e a realização institucional da paz
}

Não obstante suas repercussões jurídicas, notadamente aquelas decorrentes de sua institucionalização, a consolidação da cooperação internacional foi, antes de qualquer coisa, um processo histórico e um dos vetores centrais do direito internacional no século XX.

As Organizações Internacionais se desenvolveram num processo de intensificação e estreitamento da cooperação internacional. Dessa forma, para compreendermos o processo histórico e as forças que motivaram a sua criação, além das implicações de sua contínua evolução funcional, parece-nos indispensável tratá-las como uma etapa do processo de transformação do direito internacional e, também, como um avanço na construção e implantação da paz na atualidade.

Comumente entendemos que as Organizações Internacionais são resultantes da vontade dos Estados, possuindo uma existência como ente que emana do interesse coletivo, não se confundindo com os indivíduos ou as entidades que as constituíram ou as compuseram.

Encerram-se também como um conjunto de normas de conduta que regula a coexistência dos Estados nacionais, conservando-se a soberania de cada um.

\footnotetext{
${ }^{207}$ LAFER, Celso. Kant e a razão abrangente da humanidade no percurso de Sérgio Vieira de Mello. In: MARCOVITCH, Jacques (Org.). Sérgio Vieira de Mello: pensamento e memória, cit., p. 31.
} 
As Organizações Internacionais surgiram efetivamente nos finais do século XIX e contribuíram de forma considerável para o desenvolvimento do direito internacional contemporâneo.

O final da Primeira Guerra Mundial trouxe a constituição da Liga das Nações, que teve sua atuação prejudicada pela ausência de comprometimento dos Estados membros, bem como na sua estruturação igualitária, pela qual qualquer membro teria poder de veto às determinações da Organização.

Neste esteio, a criação de diversas Organizações Internacionais de alcance global ou regional teve seu ápice ao final da Segunda Guerra Mundial, como a Organização do Tratado do Atlântico do Norte - OTAN - e o Conselho Europeu, dentre outras organizações internacionais, sendo necessário ressaltar que a Organização dos Estados Americanos - OEA - é anterior a Primeira Guerra mundial, ainda que rudimentarmente estruturada.

\subsubsection{Da Liga das Nações à Organização das Nações Unidas}

O primeiro documento programático sobre uma reorganização da sociedade internacional no pós-Segunda Guerra Mundial foi a Carta do Atlântico, de 14 de agosto de 1941. Essa Carta foi, em verdade, uma declaração conjunta do primeiro-ministro britânico Winston Churchill e do presidente norte-americano Roosevelt.

Os norte-americanos reivindicam a criação da Liga das Nações, mas parecenos que é imperativa a inspiração de algumas reflexões teóricas aqui apresentadas, com especial destaque para Kant.

Alcançar uma paz duradoura entre os Estados é um objetivo antigo na história do direito internacional, conforme procuramos demonstrar ao longo do presente trabalho, e seus marcos iniciais mais importantes, remontam para a Paz de Vestfália, de $1648 .^{208}$

\footnotetext{
${ }^{208}$ Nessa linha, Luiz Ricardo Miranda escreve, em tese de doutoramento, que "podemos eleger como marco de uma tentativa de institucionalização da paz no mundo, a denominada "Paz de Vestfália", de 24 de outubro de 1648, foi ela a primeira grande assembleia da paz na Europa, colocou um ponto final nas ações belicosas do Império Romano-Germânico. Essa paz era mais que um acordo de paz, era uma
} 
A institucionalização da cooperação internacional constituiu uma transformação copérnica no direito internacional contemporâneo.

Em $1^{\text {o }}$ de janeiro de 1942 foi assinada em Washington a "Declaração das Nações Unidas", usando-se pela primeira vez a expressão "Nações Unidas" atribuída à Franklin Delano Roosevelt.

Três anos depois, em 1945 é convocada na cidade de São Francisco (cidade norte-americana) uma conferência, cuja duração foi do dia 25 de abril a 26 de junho do mesmo ano.

O fruto da reunião foi a "Carta das Nações Unidas" e, por conseguinte, a constituição de uma nova Organização Internacional: a ONU. A Carta da ONU foi elaborada pelos 50 países presentes na conferência mencionada.

A própria designação "Carta”, no âmbito do Direito Internacional Público, é de extrema relevância, pois se dá essa nomenclatura ao acordo multilateral internacional cujo objeto seja universal.

Assim sendo, a única Carta em vigência na atualidade é, justamente, a das Nações Unidas. Luigi Ferrajoli, em A Soberania no Mundo Moderno, lembra que a Carta constitui marco de um novo direito internacional, com traços de um verdadeiro contrato social.

Nesse contexto, o jurista italiano argumenta que a Carta teria transformado a estrutura do direito internacional, que, na sua evolução, passou de um corpus que ele denomina pactício, baseado em tratados bilaterais, a um ordenamento jurídico

ordenação pacifista fundamental para o Antigo Regime e para o Universo europeu. O objetivo desse congresso de paz era um ordenamento de alcance europeu, de caráter universal e permanente. Consequentemente, a pax começou como seguinte artigo "Pax sit christiana, universalis, perpetua veraque...eaque ita sincere e serioque servetur et colatur, ut utraque pars alterius utilitatem, honorem ac commodum promoveat(...)", que a paz seja cristã, universal, perpétua e verdadeira.....e deveria ser mantida e cultivada sinceramente e seriamente a fim de cada uma das partes promova a utilidade, a honra e a vantagem da outra(...). As negociações de Münster e Osnabrück (cidades na Vestfália), em verdade realizaram no âmbito político as reflexões teóricas sobre a guerra e a paz anteriormente desenvolvidas." MIRANDA, Luiz Ricardo. O Grupo Banco Mundial e a regulação internacional do financiamento de projetos (Project finance). 2013. Tese (Doutorando) - Faculdade de direito da Universidade de São Paulo, São Paulo, 2013. p. 14-16. 
propriamente, um ordenamento supraestatal, caracterizado pela vigência não só de um pactum associationis, mas também de um pactum subiectiones. ${ }^{209}$

O preâmbulo da Carta das Nações Unidas traz em seu texto os ideais e os propósitos dos povos que se uniram para constituir uma Organização Internacional como anseio direto das reflexões teóricas de paz que encontra suas raízes nos projetos de paz apresentados nos capítulos iniciais deste trabalho.

Temos, em última análise, que os membros da ONU foram unidos visceralmente pela Carta, essa enunciadora dos direitos e deveres dos membros da comunidade internacional $^{210}$ e que ela reflete uma lição da História: a paz só pode ser mantida ao adotarmos uma estrutura capaz de viabilizá-la.

Sabidamente, a ONU foi criada para ser uma estrutura voltada às operações diplomáticas $^{211}$, pois, depois das penosas experiências bélicas da Primeira e da Segunda Guerras Mundiais, percebeu-se que somente a diplomacia poderia selar a paz.

Contudo, ressalta-se que a Organização em apreço não é um mecanismo exclusivo, mas um instrumento "suplementar de todos os outros métodos de relações

\footnotetext{
209“"A carta da ONU assinala, em suma, o nascimento de um novo direito internacional e o fim do velho paradigma - o modelo Vestfália -, que se firmara três séculos antes com o termino de outra guerra europeia dos trinta anos. Tal carta equivale a um verdadeiro contrato social internacional - histórico e não metafórico, efetivo ato constituinte e não simples hipótese teórica ou filosófica -, com o qual o direito internacional muda estruturalmente, transformando-se de sistema pactício, baseado em tratados bilaterais inter pares (entre partes homogêneas), num verdadeiro ordenamento jurídico supra-estatal: não mais um simples pactum associationis (pacto associativo), mas também pactum subiectiones (pacto de sujeição). Mesmo porque a comunidade internacional, que até a Primeira Guerra Mundial ainda era identificada com a comunidade das "nações cristãs" ou civilizadas - Europa e América -, é estendida pela primeira vez a todo o mundo como ordem jurídica mundial." FERRAJOLI, Luigi. op. cit.

${ }^{210} \mathrm{Em}$ seu curso de direito internacional público, o professor Celso D. de A. Mello diferencia "comunidade internacional" da "sociedade internacional": "A comunidade apresentaria as características: formação natural; vontade orgânica (energia própria ao organismo, manifestando-se no prazer, no hábito e na memória); e os indivíduos participam de maneira mais profunda da vida comum.

211 “'The main themes are power and accountability. Where does power-legal and political-lie within the organization? Is the exercise of power legitimate, in the sense not only of complying with the constitutional order but also of inducing member state into voluntary compliance? Transparency is part of the that question. If an organ's decision are regarded as legitimate, the greater likehood that the membership will accept and implement them. This goes to the heart of the effectiveness of the UN system." WHITE, Nigel D. The United Nations system: toward international justice. Colorado: Rienner, 2002. p. 70.
} 
internacionais, e também não é um órgão que suplantaria inteiramente aqueles últimos"212.

Por ocasião dos 60 anos da ONU Casella teceu as seguintes considerações que merecem destaque.

\begin{abstract}
"Justamente no esforço de criação da ONU e de instauração de novo e mais elevado patamar de regulação do uso da força pelo direito internacional se buscou conferir efetividade e consistência que haviam faltado a duas tentativas anteriores, que conservam seu papel como precedentes e como indicadores de tendência, a seguir retomada no seio da nova organização.
\end{abstract}

A ONU e as demais organizações intergovernamentais vieram mudar significativamente $o$ direito internacional atual, resultantes do aumento das relações internacionais e da necessidade da cooperação entre os Estados, em assuntos os mais variados, em âmbitos quer regional como multilateral em sua acepção mais ampla, como no caso da ONU. A multilateralidade se torna elemento característico do direito internacional atual, sem prejuízo do papel de acordos regionais, como teria prenunciado o sistema interamericano e como demonstra o processo europeu de integração.

(...)

A nova configuração operacional do direito internacional vigente vem reforçar os imperativos de construção de base consensual e de mútua aceitação das regras desse campo normativo. Em arena como a de uma organização intergovernamental de vocação mundial os estados não pode pretender que "todos sejam iguais, mas uns sejam mais iguais que os outros", na formulação da "revolução dos bichos" de ORWELL: a igualdade soberana e isonomia jurídica, a necessidade de observância dos mesmos limites à ingerência em assuntos internos e a base consensual do sistema normativo internacional tem de ser observadas por todos, sob pena de esvaziar o todo."

${ }^{212}$ PASVOLKY, Leo. Discurso na Universidade de Illinois em 2 de maio de 1950, apud GROSS, Ernest A. As Nações Unidas: estrutura da paz. Tradução: Waldemir Nogueira Araújo. Rio de Janeiro: Edições GDR, 1964. p. 22.

${ }^{213}$ CASELLA, Paulo Borba. ONU pós-Kelsen. In: MERCADANTE, Araminta de Azevedo; MAGALHÃES, José Carlos de (Orgs.). Reflexões sobre os 60 anos da ONU. Ijuí: Unijuí, 2005. p. 19 e ss. 


\subsection{Assembleia Geral da ONU como reflexo do pensamento de paz kantiano}

A Assembleia Geral norteia sua atuação pela Carta das Nações Unidas e pelo seu Regimento, aprovado pelos seus membros, a partir do artigo 10 de referida Carta. Ela tem por função fazer recomendações sobre os princípios da cooperação internacional para a manutenção da paz e da segurança mundial. Haja vista que ela representa a opinião da sociedade internacional, a Assembleia também pode discutir quaisquer questões afetas à paz e a segurança, desde que esta situação não esteja sendo discutida pelo Conselho de Segurança.

A competência residual da Assembleia Geral da ONU foi consagrada na Resolução $377^{214}$ de 1950, conhecida como "Uniting for peace" ou "Dean Acheson Resolution", tendo sido esse o meio encontrado pelo Secretário de Estado dos Estados Unidos para ultrapassar o boicote soviético à sessão que analisaria a crise provocada pela Guerra na Coreia, em 1950. Ainda que a Resolução da Assembleia Geral não possua coercibilidade, ela emprestou legitimidade ao uso da força por recomendar o uso de tal procedimento com apoio do artigo 11 da Carta da ONU.

O exercício da competência residual que ela reserva à Assembleia será possível quando o Conselho de Segurança não exercer a função que lhe cabe, como órgão originariamente competente para manutenção da paz e segurança internacional.

Outras funções da Assembleia Geral são incentivar e iniciar estudos que tenham por escopo promover a cooperação política internacional, o desenvolvimento do Direito Internacional e sobremaneira a sua codificação, bem como apreciar os relatórios do Conselho de Segurança e de qualquer outro órgão ou organismo do sistema das Nações Unidas.

Contudo, uma de suas atribuições mais importantes é eleger os dez membros não-permanentes do Conselho de Segurança.

\footnotetext{
214 “(...) In light of the subsequent practice - and despite of the fact that the legality of the resolution has continued to remain controversial - it is possible to state today that such action would not be contrary to the Charter. Since 1950, practice demonstrates an acceptance for a larger role of the General Assembly. The Council referred disputes to the General Assembly, even though the latter did not recommend a use of force. Some instances of this practices include the Suez crisis (1956), where the USSR itself cited the Acherson Resolution as a ground; following the Soviet invasion of Hungary (1956) (...)” KOLB, Robert. An introduction to the law of the United Nations. Oregon: Oxford and Portland, 2010. p. 90.
} 
A Assembleia Geral também pode participar, concomitantemente com o Conselho de Segurança, na eleição dos juízes da Corte Internacional de Justiça e é a ela que cabe nomear o Secretário Geral, por meio de recomendação do Conselho de Segurança. No tocante ao orçamento da Organização, cabe à Assembleia aprová-lo, determinar a cota de contribuição de cada membro e apreciar, também, o orçamento das agências especializadas.

Cabe comentar, por fim, outro importante órgão da ONU, que é o Conselho de Segurança, pelo qual as grandes potências conseguiram assegurar um direito de controle no interior da Organização. Daí termos, nele, a preponderância de alguns países no domínio da paz e da segurança internacional.

De pronto, podemos perceber que o órgão em apreço é, indubitavelmente, o mais polêmico das Nações Unidas. É também o mais conhecido e criticado de uma forma geral, dada a sua publicidade pela mídia. Para alguns doutrinadores, o Conselho de Segurança é o responsável "exclusivo" da manutenção da paz no mundo, conforme já comentado sobre a Resolução "Uniting for Peace”. A despeito desta possibilidade, temos, parafraseando Manuel de Almeida Ribeiro, que a preponderância do Conselho de Segurança na matéria seria explicada por sua composição, organização, processo de decisão, poderes e a engenharia da própria $\mathrm{ONU}$, que estabelece os termos das relações do Conselho com seus demais órgãos. ${ }^{215}$

No tocante às suas competências, temos que o Conselho de Segurança é o órgão político por excelência das Nações Unidas. Como se disse, cabe a ele, de forma precípua, manter a paz e a segurança no mundo em consonância com os propósitos da ONU.

Incumbe ao órgão em comento, também, ficar atento a qualquer controvérsia que possa transformar-se em um atrito internacional, estando os países-membros da Organização obrigados a aceitar e cumprir as suas decisões. Justamente por essa obrigatoriedade, as decisões do Conselho se distinguiriam das decisões dos demais órgãos da ONU.

${ }^{215}$ RIBEIRO, Manuel de Almeida. A Organização das Nações Unidas. Coimbra: Almedina, 1998. p. 74. 
Talvez as atuações mais pontuais deste órgão sejam as aplicações das chamadas sanções econômicas nos países que transgridam os valores da Carta e empreender a ações militares.

O funcionamento do Conselho de Segurança dá-se de forma contínua e sempre um representante de cada um dos seus membros deve estar sempre presente na sede das Nações Unidas. Sua presidência é exercida dentro de um sistema de rodízio, inclusive pelos membros não-permanentes, no período de um mês. 


\section{CONCLUSÃO}

“Ele não propunha nenhuma solução já pronta, apenas princípios e a vontade de prosseguir em sua busca. Era dessa liberdade que Kant nos falava, ao nos lembrar que "devemos agir como se a coisa, que talvez não seja, fosse"(...) Mais do que nunca, ao olharmos a nossa volta, uma evidência nos interpela: o futuro é para ser inventado. Afastar-se desse nobre desígnio equivaleria a renunciar à nossa razão de ser, que consiste em sermos razão". (Sérgio Vieira de Mello)

A definição do conceito de "paz" ao longo da história da humanidade, e também do direito internacional, guardou estreita conexão com o conceito de "guerra", impondo-se a constatação de que entre dois termos opostos, um é definido por meio do outro, como um "movimento", no caso dos dois contrários - paz e guerra - é sempre o primeiro que é definido por meio do segundo ${ }^{216}$.

Nesse sentido, enquanto o conceito de "guerra" é definido de forma positiva com a enumeração de conotados caracterizantes, o conceito de "paz" é definido negativamente, como a ausência de guerra ${ }^{217}$.

Todavia, o que se buscou no trabalho foi promover uma subversão, conceituar e valorar a paz de forma desconecta ao conceito da guerra, no intuito claro de demonstrar a sua existência independente.

Em uma passagem da Crítica do Juízo, Kant disse que, na ausência de um sistema jurídico de todos os Estados, a guerra é inevitável, asseverando que ela é oriunda da irresponsabilidade inerente dos homens, mas logo em seguida acrescenta que a guerra "talvez esconda profundamente um projeto da sabedoria suprema, pelo menos para preparar, se não para estabelecer, a conciliação da legalidade com a liberdade dos Estados, e, portanto a união destes num sistema moralmente fundado ${ }^{218}$ ".

\footnotetext{
${ }^{216}$ BOBBIO, Norberto. O positivismo jurídico: lições de filosofia do direito. Tradução: Márcio Pugliesi, Edson Bini e Carlos E. Rodrigues. São Paulo: Ícone, 2006. p. 139-140.

${ }^{217}$ Id. Ibid., p. 140.

${ }^{218}$ KANT, Immanuel apud BOBBIO, Norberto. O problema da guerra e as vias da paz, cit., p. 87. Pela tradução de A. Gargiulio. Bari: Laterza, 1923. p. 305.
} 
Por esse motivo, optou-se em trazer no bojo do trabalho a simbólica da paz por meio da investigação teórica do conceito, na tradição dos projetos de paz perpétua do pensamento ocidental, em especial os projetos do período moderno.

Assim, percebe-se que a tônica da pesquisa recaiu no ideal da construção da paz ao longo da história e do direito internacional.

Indubitável que as contribuições teóricas acerca da paz em junção com os projetos de paz perpétua serviram de fundamento para a investigação realizada por Kant, que resultou em uma verdadeira sistematização racional do tema pelo filósofo.

Pode-se perceber que Kant introduz e inova na construção de sua teoria de paz, vez que entende que essa não é apenas uma ideia vazia ou um sonho. A paz é, sim, um dever prescrito para a humanidade.

Na sua lição, a instituição de uma paz universal é o objetivo último e principal do Direito Internacional Público, que pode ser tomado como arma para se lutar por essa paz com a força da razão no lugar da força das armas.

Em síntese, o fim para o qual tendeu a história humana foi realmente a constituição de uma sociedade jurídica que busca uma paz com liberdade de soberania interna, ao molde do que já previa Kant em sua "Liga das Nações", preconizada por seu projeto de paz perpétua.

No direito internacional contemporâneo, a institucionalização da contínua busca pela paz consubstanciou-se na criação das Organizações Internacionais, e para o presente trabalho a Organização que melhor representa a proposta kantiana é a ONU.

A Organização das Nações Unidas, na atualidade, avocou para si a responsabilidade de ser um foro de discussão dos problemas mundiais, com o propósito de manter a paz e a segurança internacionais, além de tentar desenvolver relações de cooperação internacional entre as nações ${ }^{219}$.

\footnotetext{
${ }^{219}$ MENEZES, Wagner. A contribuição da ONU para a formação do direito internacional contemporâneo. In: MERCADANTE, Araminta de Azevedo; MAGALHÃES, José Carlos de (Orgs.). Reflexões sobre os 60 anos da ONU. Ijuí: Unijuí, 2005. p. 552.
} 
Com efeito, acerca do direito cosmopolita, Kant não o vê como uma quimera, uma representação fantástica de mentes exaltadas. Ele o vê como uma das condições necessárias para a busca da paz perpétua, com fundamento em um direito público da humanidade, para uma época da história em que a violação ao direito ocorrida num ponto do planeta venha a ser sentida em todos os outros.

Cumpre dizer que, apesar de articulado em torno do legado de Kant, o trabalho não é, pois, tão ingênuo ou deslumbrado perante o "problema da paz" quanto pode parecer. Procurou-se abordar a paz, fruto de esforços de todas as ordens, com destaque para o direito internacional ao longo de sua história e, atualmente, por meio da atuação das Organizações Internacionais, em vista da construção de uma paz possível.

Kant teria dito que devemos trabalhar pela paz universal mesmo que não saibamos se "a paz perpétua" é uma coisa real ou um contrassenso, isto é, "devemos agir sobre o seu fundamento, como se a coisa fosse possível", e é assim que acreditamos. 


\section{REFERÊNCIAS}

ACCIOLY, Hildebrando. Tratado de direito internacional público. 3. ed. São Paulo: Quartier Latin, 2009. v. 1 e 2.

; SILVA, Geraldo Eulálio do Nascimento e; CASELLA, Paulo Borba. Manual de direito internacional público. 17. ed. São Paulo: Saraiva, 2009.

AGO, R.; SCHIEDERMAIR, W; RIPHAGEN, A; TRUYOL SERRA; FEENSTRA, R. Commemoration of the Fourth Centenary of the Birth of Grotius. Recueil des Cours, Haye, v. 232, n. 1, p. 399, 1992. (Collected Courses of The Hague Academy of International Law).

ALLISON, Henry E. Idealism and freedom: essays on Kant's theoretical and practical philosophy. Cambridge: Cambridge, 1996.

AMARAL JÚNIOR, Alberto do. Curso de direito internacional público. 2. ed. São Paulo: Atlas, 2011.

ARAUJO, Luiz Ivani de Amorim. Os organismos especializados da ONU. In: MERCADANTE, Araminta de Azevedo; MAGALHÃES, José Carlos de (Orgs.). Reflexões sobre os 60 anos da ONU. Ijuí: Unijuí, 2005. p. 13-82.

ARENDT, Hannah. Lições sobre a filosofia política de Kant. Tradução: André Duarte de Macedo. Rio de Janeiro: Relume-Dumará, 1993.

ARIOSI, Mariângela. Conflitos entre tratados Internacionais e Leis internas: o judiciário brasileiro e a nova ordem internacional. Rio de Janeiro: Renovar, 2000.

ARISTÓTELES. Ética a Nicômaco. Tradução: Pietro Nassetti. São Paulo: Martin Claret, 2003.

ARON, Raymond. Paz e guerra entre as Nações. Tradução: Sérgio Bath. São Paulo: UnB, 2002.

BAILEY, Sidney D. A história das Nações Unidas. Tradução: João Paulo Monteiro. Rio de Janeiro: Lidador, 1965.

BARCIA TRELLES, Camilo. Francisco de Vitoria et l'ecole moderne du droit internacional. Recueil des Cours, Haye, t. 17, v. 2, p. 109-342, 1927. (Collected Courses of The Hague Academy of International Law). 
BARCIA TRELLES, Camilo. Francisco Suarez (1548-1617): les théologiens espagnols du XVI siècle et l'école moderne du Droit international). Recueil des Cours, Haye, v. 43, p. 388-553, 1933. (Collected Courses of The Hague Academy of International Law).

BENTHAM, Jeremy. An introduction to the principles of morals and legislation. New York: Dover, 2007.

Ensaio IV: um plano para uma paz universal e perpétua. Brazilian Journal of International Relations, v. 1, n. 1, p. 158-186, 2012. Disponível em: $<$ http://pt.scribd.com/doc/88879765/BENTHAM-J-Um-plano-para-uma-paz-universal-eperpetua $>$.

Essay IV: a plan for an universal and perpetual peace (1843), from The Works of Jeremy Bentham v. 2, edited by John Bowring (Edinburgh: William Tait, 1843). Disponível em: <http://perpetualpeaceproject.org/resources/bentham.php>. Acesso em: 21 mar. 2013.

BITTAR, Eduardo C. B.; ALMEIDA, Guilherme Assis de. Curso de filosofia do direito. 8. ed. São Paulo: Atlas, 2010.

BOBBIO, Norberto. Direito e Estado no pensamento de Immanuel Kant. Tradução: Alfredo Fait. Brasília: Ed. da UnB, 1984.

. A era dos direitos. Tradução: Carlos Nelson Coutinho. 13. tir. Rio de Janeiro: Elsevier, 2004.

. O positivismo jurídico: lições de filosofia do direito. Tradução: Márcio Pugliesi, Edson Bini e Carlos E. Rodrigues. São Paulo: Ícone, 2006.

O problema da guerra e as vias da paz. Tradução: Álvaro Lorencini. São Paulo: UNESP, 2002.

BOUVIER, Antoine A. Direito internacional humanitário e direito dos conflitos armados. Williamsburg (EUA): Instituto para Treinamento em Operações de Paz, 2011.

BROWNLIE, Ian. International law at the fiftieth anniversary of the United Nations: General Course on Public International Law. Recueil des Cours, Haye, t. 255, v. 1, 1995. (Collected Courses of The Hague Academy of International Law).

Princípios de direito internacional público. Tradução: Maria Manuela Farrajota, Maria João Santos, Victor Richard Stockinger e Patrícia Galvão Teles. 4. ed. Lisboa: Calouste Gulbenkian, 1997. 
CAMPOS, João Mota de (Org.). Organizações internacionais. Lisboa: Fundação Calouste Gulbenkian, 1999.

CARREAU, Dominique. Droit internacional. 7. ed. Paris: Éditions A. Pedone, 2001.

CASELLA, Paulo Borba. Desenvolvimento do direito internacional na concepção de Cornelius van Bynkershoek. Revista da Faculdade de Direito da Universidade de São Paulo, São Paulo, v. 103, p. 563-592, 2008.

. Direito internacional no Tempo Antigo. São Paulo: Atlas, 2012.

. Direito internacional no Tempo Medieval e Moderno até Vitória. São Paulo: Atlas, 2012.

_ Fundamentos do direito internacional pós-moderno. São Paulo: Quartier Latin, 2008.

. ONU pós-Kelsen. In: MERCADANTE, Araminta de Azevedo; MAGALHÃES, José Carlos de (Orgs.). Reflexões sobre os 60 anos da ONU. Ijuí: Unijuí, 2005. p. 13-64.

Pax perpetua - a review of the concept from the perspective of economic integration. In: (Coord.). Dimensão internacional do direito: estudos em homenagem a G. E. do Nascimento e Silva. São Paulo: LTr, 2000. p. 69-88.

. Tratado de Versalhes na história do direito internacional. São Paulo: Quartier Latin, 2007.

; NASCIMENTO, Guilherme Figueiredo. Direitos dos povos indígenas: releitura de Francisco de Vitória enfatizando os 500 anos de descobrimento. Revista da Faculdade de Direito da Universidade de São Paulo, São Paulo, v. 95, p. 121-128, 2000.

CASSESE, Antonio. International law. 2. ed. Oxford: New York, 2005.

CÍCERO, Marcos Túlio. Da República. Tradução: Amador Cisneiros. 2. ed. São Paulo: Edipro, 2011.

. Tratado das Leis. Tradução: Marino Kury. Caxias do Sul: Educs, 2004.

COMPARATO, Fábio Konder. A afirmação histórica dos direitos humanos. 3. ed. 2. tir. São Paulo: Saraiva, 2004.

Ética, direito e religião no mundo moderno. 3. ed. São Paulo: Companhia das Letras, 2006. 
CONFORTI, Benedetto. The law and practice of the United Nations. Haia: Kluwer Law International, 1996.

DAL RI JUNIOR, Arno. Evolução histórica e fundamentos político-jurídicos da cidadania. In: ; OLIVEIRA, Odete Maria de (Orgs.). Cidadania e nacionalidade: efeitos, perspectivas, nacionais, regionais, globais. 2. ed. Ijuí (RS): Ed. Ijuí, 2003.

DELMAS-MARTY, Mireille. Três desafios para um direito mundial. Tradução: Fauzi Hassan Choukr. Rio de Janeiro: Lúmen Júris, 2003.

DINH, Nguyen Quoc; DAILLIER, Patrick; PELLET, Alain. Direito internacional público. Tradução: Vítor Marques Coelho. 2. ed. Lisboa: Calouste Gulbenkian, 2003.

DINSTEIN, Yoram. Guerra, agressão e legítima defesa. 3. ed. Barueri: Manole, 2004.

DU NIPPOLD, O. Le développement historique droit international depuis le Congrès de Vienne. Recueil des Cours, Haye, v. 1, n. 2, p. 1-121, 1924. (Collected Courses of The Hague Academy of International Law).

DUPUY, Charles. Les antécédents de la société des nations. Recueil des Cours, Haye, n. 2, p. 1-109, 1937. (Collected Courses of The Hague Academy of International Law).

EICHELBERG, Clark M. UN: The first ten years. New York: Harper and Brothers, 1955.

FERRAJOLI, Luigi. A soberania no mundo moderno. Tradução: Carlo Coccioli, Marcio Lauria Filho. 2. ed. São Paulo: Martins Fontes, 2007.

FERRY, Luc. Kant: uma leitura das três críticas. Tradução: Karina Jannini. 2. ed. Rio de Janeiro: Difel, 2010.

FLOH, Fabio. Direito internacional contemporâneo: elementos para a configuração de um direito internacional na Ordem internacional Neo-Vestifaliana. In: CASELLA, Paulo Borba; CELLI JR., Umberto; MEIRELLES, Elizabeth de Almeida; POLIDO, Fabrício Bertini Pasquot (Orgs). Direito internacional, humanismo e globalidade. São Paulo: Atlas, 2008. p. 219-235.

FRIEDMANN, Wolfgang. The changing structure of international law. New York: Columbia University Press, 1964.

FUSTEL DE COULANGES, Numa Denis. A cidade antiga: estudo sobre o culto, o direito e as instituições da Grécia e de Roma. Tradução: Roberto Leal Ferreira. São Paulo: Martin Claret, 2009. 
GENTILE, Alberico. O direito de guerra. Tradução: Ciro Mioranza. Ijuí: Unijuí, 2005.

GILISSEN, John. Introdução histórica ao direito. Tradução: A. M. Hespanha e L.M. Macaísta Malheiros. 4. ed. Lisboa: Calouste Gulbenkian, 2003.

GROSS, Ernest A. As Nações Unidas: estrutura da paz. Tradução: Waldemir Nogueira Araújo. Rio de Janeiro: Edições GDR, 1964.

GROTIUS, Hugo. O direito da guerra e da paz. Tradução: Ciro Mioranza. 2. ed. Ijuí: Unijuí, 2005. v. 1 e 2.

Mare liberum. The Hague: Brill, 2009.

GUINSBURG, J. (Org.). A paz perpétua: um projeto para hoje. Tradução: J. Guinsburg. São Paulo: Perspectiva, 2004.

GUYER, Paul. Introdução: o céu estrelado e a lei moral. In: GUYER, Paul (Org.). Kant. Tradução: Cassiano Terra Rodrigues. Aparecida/SP: Idéias e Letras, 2009. p. 17-44.

HABERMAS, Jürgen. A constelação pós-nacional e o futuro da democracia. In:

A constelação pós-nacional: ensaios políticos. Tradução: Márcio Selligmann-Silva. São Paulo: Littera Mundi, 2001. p.75-142.

La paix perpétuelle: le bicentenaire dúne idée kantienne. Tradução: Rainer Rochlitz. Paris: Humanités, 2005.

I. Retorno à metafísica? 2. A metafísica após Kant. In: Pensamento pósmetafísico: ensaios filosóficos. Tradução: Lumir Nahodil. Coimbra: Almedina, 2004. p. $37-52$.

THE HAGUE ACADEMY OF INTERNATIONAL LAW. History. Disponível em: <http://www.hagueacademy.nl/?history>. Acesso em: 13 nov. 2012.

HEIDEGGER, Martin. Kant et le problème de la métaphysique. Tradução: Alphonse de Waelhens e Walter Biemel. Frankfurt: Gallimard, 1965.

HUNTINGTON, Samuel P. The clash of the civilizations and the remaking of world order. New York: Simon and Schuster Paperbacks, 2003.

JUNG, Carl Gustav. Técnicas para uma alteração da disposição humana em prol da paz mundial. Tradução e Adaptação: Petho Sandor. Resposta a uma solicitação da UNESCO em 1948. São Paulo: Sedes Sapientae (arquivos), 2000. 
KANT, Immanuel. Começo conjectural da história humana. Tradução: Edmilson Menezes. São Paulo: UNESP, 2010.

. Conflito das faculdades. Tradução: Arthur Mourão. Lisboa: Ed. 70, 1993.

. Crítica da faculdade do juízo. Tradução: Valério Rohden e António Marques. 3. ed. Rio de Janeiro: Forense Universitária, 2012.

Crítica da razão prática. Tradução: Paulo Barrera. São Paulo: Ícone, 2005.

. Crítica da razão pura. Tradução: Lucimar A. Coghi Anselmi e Fulvio Lubisco. São Paulo: Ícone, 2011.

Doutrina do direito. Tradução: Edson Bini. 2. ed. São Paulo: Ícone, 1993.

. Escritos pré-críticos. Tradução: Jair Barbosa, Joãosinho Beckemkamp, Luciano Codato, Paulo Licht dos Santos e Vinicius de Figueiredo. São Paulo: Ed. UNESP, 2005.

. O fim de todas as coisas. In: TEXTOS seletos. Tradução: Floriano de Sousa Fernandes. 8. ed. Petrópolis: Vozes, 2012. p. 92-107.

. Fundamentação da metafísica dos costumes. In: . Fundamentação da metafísica dos costumes e outros escritos. Tradução: Leopoldo Holzbarch. São Paulo: Martin Claret, 2005. p. 13-96.

Ideia de uma história universal de um ponto de vista cosmopolita. Tradução: Ricardo R. Terra e Rodrigo Naves. 3. ed. 2. tir. São Paulo: Martins Fontes, 2011.

. Lógica. Tradução: Arthur Morão. Lisboa: Texto e Grafia, 2009.

A metafísica dos costumes. Tradução: Edson Bini. São Paulo: Folha de São Paulo, 2010. (Coleção Folha: livros que mudaram o mundo, v. 8).

. Prolegômenos a toda metafísica futura. Tradução: Arthur Morão. Lisboa: Edições 70, 2008.

Que significa orientar-se no pensamento? In: TEXTOS seletos. Tradução: Floriano de Sousa Fernandes. 8. ed. Petrópolis: Vozes, 2012. p. 46-62.

Resposta à pergunta: Que é "Esclarecimento" (Aufklärung)? In: TEXTOS seletos. Tradução: Floriano de Sousa Fernandes. 8. ed. Petrópolis: Vozes, 2012. p. 63-71. 
KANT, Immanuel. Rumo à paz perpétua. Tradução: Heloísa Sarzana Pugliesi. Edição Bilingüe. São Paulo: Ícone Ed., 2010.

. Sobre a discordância entre a moral e a política a propósito da paz perpétua? In: TEXTOS seletos. Tradução: Floriano de Sousa Fernandes. 8. ed. Petrópolis: Vozes, 2012. p. 79-91.

Sobre um suposto direito de mentir por amor à humanidade. In: TEXTOS seletos. Tradução: Floriano de Sousa Fernandes. 8. ed. Petrópolis: Vozes, 2012. p. 72-78.

KELSEN, Hans. The law of the United Nations. New York: Frederick A. and Praeger, 1951.

A paz pelo direito. Tradução: Lenita Ananias do Nascimento. São Paulo: Martins Fontes, 2011.

Princípios do direito internacional. Tradução: Ulrich Dressel e Gilmar Antonio Bedin. Ijuí: Unijuí, 2010.

. Teoria geral do direito e do Estado. Tradução: Luís Carlos Borges. São Paulo: Martins Fontes, 2000.

KOLB, Robert. An introduction to the law of the United Nations. Oregon: Oxford and Portland, 2010.

KORFF, Serge A. Introduction à l'histoire du droit international. Recueil des Cours, Haye, v. 1, p. 5-23, 1923. (Collected Courses of The Hague Academy of International Law).

LACROIX, Jean. Kant e o kantismo. Tradução: Maria Manuela Cardoso. Porto: Rés, 1996.

LAFER, Celso. Na confluência entre o pensar e o agir: sobre uma experiência com os conceitos de Hannah Arendt. In: . Hannah Arendt: pensamento, persuasão e poder. 2. ed. São Paulo: Paz e Terra, 2003. p. 173-194.

Kant e a razão abrangente da humanidade no percurso de Sérgio Vieira de Mello. In: MARCOVITCH, Jacques (Org.). Sérgio Vieira de Mello: pensamento e memória. 1. ed. São Paulo: Saraiva, 2004. p. 27-34.

A reconstrução dos direitos humanos: um diálogo com o pensamento de Hannah Arendt. 6. ed. São Paulo: Companhia das letras, 2006. 
LEDERMANN, László. Les précurseurs de l'organisation internacionale. Nêuchatel: Èditions de la Baconnière, 1945.

LEITE, Flamarion Tavares. 10 lições sobre Kant. Petrópolis: Vozes, 2007.

LOSANO, Mario G. (Org). Direito internacional e Estado soberano. Tradução: Marcela Varejão. São Paulo: Martins Fontes, 2002.

MAGNOLI, Demétrio (Org.). História da paz. São Paulo: Contexto, 2008.

MAQUIAVEL. Nicolau. O Príncipe. Tradução: Pietro Nassetti. São Paulo: Martin Claret, 2004.

MARQUES, Viriato Soromenho. História e política no pensamento de Kant. Portugal: Publicações Europa-América, 1994.

MASCARO, Alysson Leandro. Introdução à filosofia do direito: dos modernos aos contemporâneos. São Paulo: Atlas, 2002.

MATTOS, Adherbal Meira. Organização das Nações Unidas-60 anos. In: MERCADANTE, Araminta de Azevedo; MAGALHÃES, José Carlos de (Orgs.). Reflexões sobre os 60 anos da ONU. Ijuí: Unijuí, 2005. p. 13-82.

MELLO, Celso Duvivier de Albuquerque. Curso de direito internacional público. 13. ed. Rio de Janeiro: Renovar, 2001. v. 1 e 2.

MELLO, Sérgio Vieira de. A consciência do mundo: a ONU diante do irracional na História. In: MARCOVITCH, Jacques (Org.). Sérgio Vieira de Mello: pensamento e memória. 1. ed. São Paulo: Saraiva, 2004. p. 69-90.

- História filosófica e real: atualidade do pensamento político de Kant. In: MARCOVITCH, Jacques (Org.). Sérgio Vieira de Mello: pensamento e memória. 1. ed. São Paulo: Saraiva, 2004. p. 35-60.

MELlO, Valerie de Campos. Novas ameaças a paz e segurança: o papel da ONU. Cadernos Adenauer (Reformas na ONU), Rio de Janeiro, ano 6, n. 1, p. 13-28, 2005.

MENEZES, Wagner. A contribuição da ONU para a formação do direito internacional contemporâneo. In: MERCADANTE, Araminta de Azevedo; MAGALHÃES, José Carlos de (Orgs.). Reflexões sobre os 60 anos da ONU. Ijuí: Unijuí, 2005. p. 546-562. 
MERCADANTE, Araminta de Azevedo. Algumas questões específicas no direito internacional: língua dos tratados e reforma da ONU. In: CASELLA, Paulo Borba; CELLI JR., Umberto; MEIRELLES, Elizabeth de Almeida; POLIDO, Fabrício Bertini Pasquot (Orgs). Direito internacional, humanismo e globalidade. São Paulo: Atlas, 2008. p. 373-390.

MIRANDA, Luiz Ricardo. O Grupo Banco Mundial e a regulação internacional do financiamento de projetos (Project finance). 2013. Tese (Doutorando) - Faculdade de direito da Universidade de São Paulo, São Paulo, 2013.

MONCADA, L. Cabral de. Filosofia do direito e do Estado. Coimbra: Coimbra Ed., 1995.

MONTEAGUDO, Ricardo. Autonomia em Rousseau e Kant. In: MARTINS, Clélia Aparecida; MARQUES, Ubirajara Rancan de Azevedo (Orgs.). Kant e o Kantismo: heranças interpretativas. São Paulo: Brasiliense, 2009. p. 303-313.

MONTESQUIEU, Charles-Louis de Secondat. Do espírito das Leis. Tradução: Jean Melville. São Paulo: Martin Claret, 2002.

MORE, Thomas. Utopia. Tradução: Paulo Neves. Porto Alegre: L e PM, 2011.

MORRIS, Clarence (Org). Os grandes filósofos do direito. Tradução: Reinaldo Guarany. São Paulo: Martins Fontes, 2002.

MOURÃO, Fernando Augusto Albuquerque. Reminiscências de Francisco Vitória nas lições de Guido Soares. In: CASELLA, Paulo Borba; CELLI JR., Umberto; MEIRELLES, Elizabeth de Almeida; POLIDO, Fabrício Bertini Pasquot (Orgs). Direito internacional, humanismo e globalidade. São Paulo: Atlas, 2008. p. 391-398.

NOUR, Soraya. O conceito de direito internacional em Kant e sua recepção na filosofia política do direito internacional e das relações internacionais. 1999. Tese (Doutorado) Faculdade de direito da Universidade de São Paulo, São Paulo, 1999.

À paz perpétua de Kant: filosofia do direito internacional e das relações internacionais. São Paulo: Martins Fontes, 2004.

PENN, William. The peace of Europe, the fruits of solitude. Great Britain: Everyman, 1993.

PERES, Daniel T. Direito, política e história em Kant. In: TRAVESSONI, Alexandre. Kant e o direito. Belo Horizonte: Mandamentos, 2009. p. 68-73. 
PETIT, Yves. Droit international du maintien de la paix. Paris: L.G.D.J., 2000.

PLATÃO. A República. Tradução: Pietro Nassetti. São Paulo: Martin Claret, 2003.

RAMEL, Frédéric; CUMIN, David. Philosophie des relations internationales. Paris: Presses de Sciences Po, 2002.

RANGEL, Vicente Marotta. Prefácio. In: VATTEL, Emmerich. O direito das gentes ou princípios da lei natural aplicados à condução e aos negócios das nações e dos governantes. Tradução: Ciro Mioranza. Ijuí: Unijui, 2008.

RAWLS, John. O construtivismo kantiano na teoria moral (1980). In: Justiça e democracia. Tradução: Irene A. Paternot. 2. ed. São Paulo: Martins Fontes, 2002. p. 43111.

O direito dos povos. Tradução: Luís Carlos Borges. 2. ed. São Paulo: Martins Fontes, 2004.

RENAUT, Alain. Kant aujord'hui. Paris: Aubier, 1997.

RIBEIRO, Manuel de Almeida. A Organização das Nações Unidas. Coimbra: Almedina, 1998.

ROHDEN, Valério (Org). Kant e a instituição da paz. Porto Alegre: Ed. da Universidade, 1997.

ROMANO, Roberto. Ensaio para um Posfácio. In: GUINSBURG, J. (Org.). A paz perpétua: um projeto para hoje. Tradução: J. Guinsburg. São Paulo: Perspectiva, 2004. p. 101-153.

ROSENFELD, Anatol. O problema da paz universal: Kant e as Nações Unidas. In: GUINSBURG, J. (Org.). A paz perpétua: um projeto para hoje. Tradução: J. Guinsburg. São Paulo: Perspectiva, 2004. p. 89-99.

ROUSSEAU, Jean Jacques. Discurso sobre a origem e os fundamentos da desigualdade entre os homens. Tradução: Lourdes Santos Machado. São Paulo: Nova Cultural, 1999. p. 5-157. (Os Pensadores).

Do contrato social. Tradução: Pietro Nassetti. São Paulo: Martin Claret, 2003. 
ROUSSEAU, Jean Jacques. O Estado de guerra nascido do Estado social. In:

Rousseau e as relações internacionais. Tradução: Sérgio Bath. Prefácio Gelson Fonseca Jr. São Paulo: Imprensa Oficial do Estado de São Paulo; Brasília: Ed. da UnB, 2003. p. 45-54. (Coleção Clássicos IPRI).

. Extrato e julgamento do Projeto de Paz Perpétua de Abbé de Saint-Pierre. In: Rousseau e as relações internacionais. Tradução: Sérgio Bath. Prefácio Gelson Fonseca Jr. São Paulo: Imprensa Oficial do Estado de São Paulo; Brasília: Ed. da UnB, 2003. p. 69-100. (Coleção Clássicos IPRI).

Fragmentos sobre a guerra. In: Rousseau e as relações internacionais. Tradução: Sérgio Bath. Prefácio Gelson Fonseca Jr. São Paulo: Imprensa Oficial do Estado de São Paulo; Brasília: Ed. da UnB, 2003. p. 61-69. (Coleção Clássicos IPRI).

Rousseau e as relações internacionais. Tradução: Sérgio Bath. Prefácio Gelson Fonseca Jr. São Paulo: Imprensa Oficial do Estado de São Paulo; Brasília: Ed. da UnB, 2003. (Coleção Clássicos IPRI).

SAINT-PIERRE, Abbé de. Projeto para tornar perpétua a paz na Europa. Tradução: S. Duarte. São Paulo: Imprensa Oficial; Brasília: Ed. da UnB, 2003. (Coleção Clássicos IPRI).

SALGADO, Joaquim Carlos. Kant: revolução e reforma no caminho da Constituição Republicana: a paz perpétua. In: TRAVESSONI, Alexandre. Kant e o direito. Belo Horizonte: Mandamentos, 2009. p. 68-73.

SALGADO, Karine. A paz perpétua de Kant: atualidade e efetivação. Belo Horizonte: Mandamentos, 2008.

SARFATI, Gilberto. Teorias de relações internacionais. São Paulo: Saraiva, 2005.

SEITENFUS, Ricardo. Manual das Organizações internacionais. 5. ed. Porto Alegre: Livr. do Advogado, 2012.

Prefácio. In: SAINT-PIERRE, Abbé de. Projeto para tornar perpétua a paz na Europa. Tradução: Sérgio Duarte. São Paulo: Imprensa Oficial; Brasília: Ed. da UnB, 2003. (Coleção Clássicos IPRI).

SHAW, Malcom N. Direito internacional. São Paulo: Martins Fontes, 2010. International law. 6. ed. Cambridge: Cambridge, 2008. 
SILVA, Carlos Eduardo Lins da. A ONU e a consciência do mundo diante do Possível. In: MARCOVITCH, Jacques (Org.). Sérgio Vieira de Mello: pensamento e memória. 1. ed. São Paulo: Saraiva, 2004. p. 61-68.

SOARES, Guido Fernando Silva. Curso de direito internacional público. São Paulo: Atlas, 2002.

SWINARSKI, Christophe. Direito internacional humanitário: como sistema de proteção internacional da pessoa humana (principais noções e institutos). São Paulo: Ed. Revista dos Tribunais; USP/NEV, 1990.

TEIXEIRA, Anderson Vichinkeski. Teoria pluriversalista do direito internacional. São Paulo: VMF Martins Fontes, 2011.

TETSUYA, Toyoda. Theory and politics of the law of nations: political bias in international law discourse of seven German Court counciliors in the seventeenth and eighteenth centuries. Leiden: Brill, 2011.

TRINDADE, Antônio Augusto Cançado. Direito das organizações internacionais. 3. ed. Belo Horizonte: Del Rey, 2003.

International law for humankind: towards a new jus gentium. Leiden: Martinus Nijhoff, 2010.

TRINDADE, Luciano José. À Paz perpétua de Kant e a sociedade internacional contemporânea. Ijuí: Unijuí, 2010. (Coleção relações internacionais e globalização).

TRUYOL Y SERRA, Antonio. História do direito internacional público. Tradução: Henrique Barrilaro Ruas. Lisboa: Instituto Superior de Novas Profissões, 1996. (Coleção Estudos Gerais).

UGARTE, José Manuel. Los conceptos jurídicos e políticos de la seguridad y la defensa. Buenos Aires: Plus Ultra, 2003.

VATTEL, Emmerich. O direito das gentes ou princípios da lei natural aplicados à condução e aos negócios das nações e dos governantes. Tradução: Ciro Mioranza. Ijuí: Unijui, 2008.

VERGEZ, André; HUISMAN, Denis. Curso moderno de filosofia. Tradução: Lélia de Almeida González. 7. ed. Rio de Janeiro: Freitas Bastos, 1980.

; HUISMAN, Denis. História dos filósofos ilustrada pelos textos. Tradução: Lélia de Almeida Gonzáles. 6. ed. Rio de Janeiro:Freitas Bastos, 1984. 
VERGUEIRO, Luiz Fabrício Thaumaturgo. Implementação da cooperação jurídica internacional vertical. 2012. Tese (Doutorado) - Faculdade de Direito da Universidade de São Paulo, São Paulo, 2012.

VISSCHER, Charles de. Théories et réalités en droit internacional public. 4. ed. Paris: Éditions A. Pedone, 1970.

VITORIA, Francisco de. Os índios e o direito da guerra. Tradução: Ciro Mioranza. Ijuí: Unijuí, 2006.

WEISS, Thomas G.; FORSYTHE, David P.; COATE, Roger A.; PEASE, Kelly-Kate. The United Nations and changing world politics. 5. ed. Colorado: Westview, 2007.

WHITE, Nigel D. The United Nations system: toward international justice. Colorado: Rienner, 2002.

WILLIFORD, Miriam. Jeremy Bentham on Spanish America: an account of his letters and proposals to the new world. Louisiana: Louisiana State University Press, 1980.

ZUCCHERINO, Ricardo Miguel. Derecho internacional privado. Buenos Aires: Lexis Nexis, 2008. 
ANEXO - ILUSTRAÇÃO 


\section{MAPA DE REORGANIZAÇÃO DA EUROPA DO DUQUE DE SULLY (MAXIMILIEN DE BETHUNE)}

Mapa da Europa proposto por Maximilien de Bethune, mais conhecido como Duque de Sully, baseado na ideia do "projeto para estabelecer uma Organização Geral, uma Arbitragem Permanente e uma proteção recíproca entre os Soberanos Cristãos", de Henrique IV, o Grande, no século XVII.

Phanche V LE PROJET de RÉORganisation EUROPEenNe DE SULLY

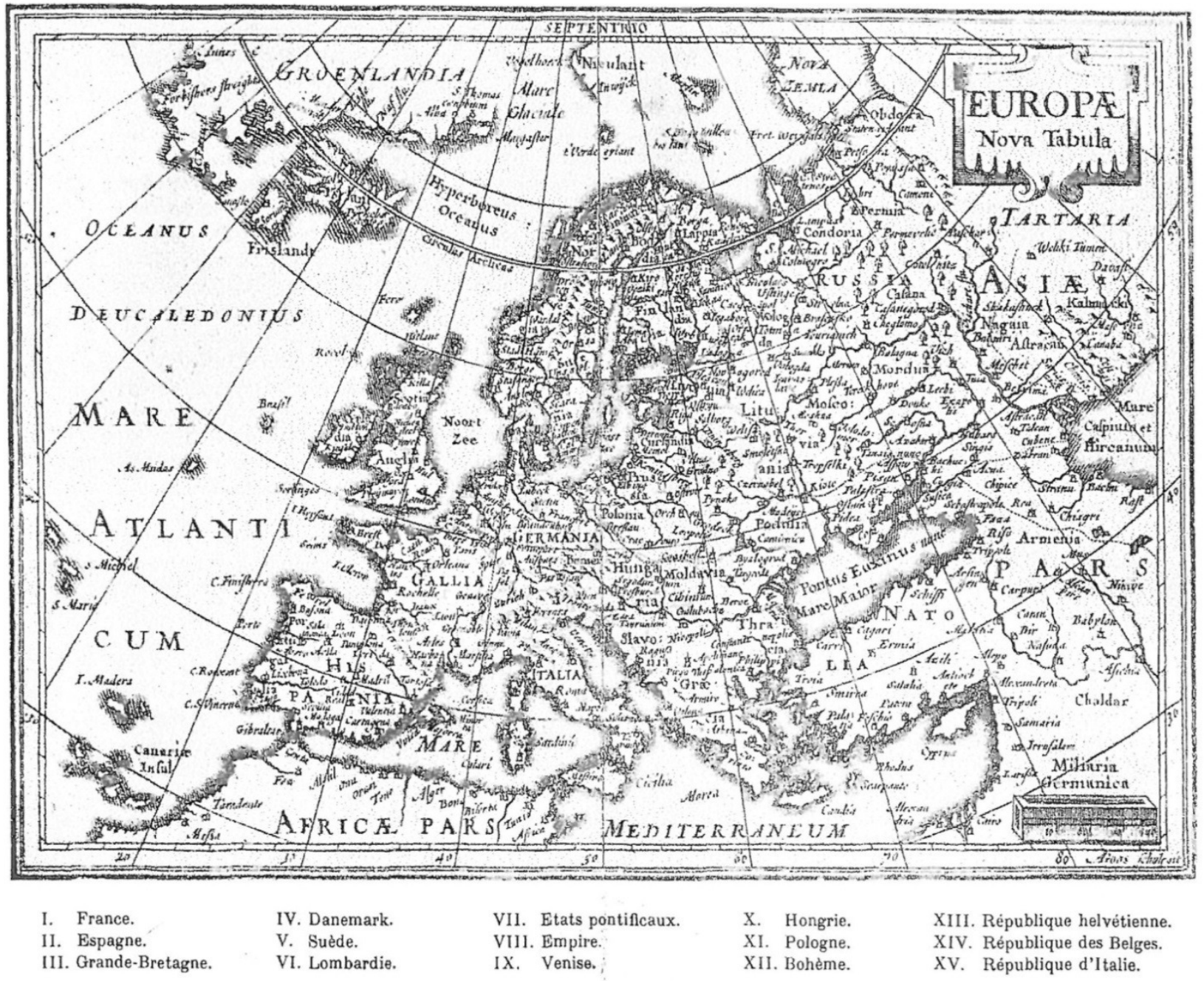

I. Mapa de Reorganização da Europa do Duque de Sully (Maximilien de Bethune)

Fonte: LEDERMANN, László. Les précurseurs de l'organisation internacionale. Nêuchatel: Ėditions de la Baconnière, 1945. p. 89. 
APÊNDICE 


\section{TÉCNICAS PARA UMA ALTERAÇÃO DA DISPOSIÇÃO HUMANA EM PROL DA PAZ MUNDIAL POR CARL GUSTAV JUNG: RESPOSTA A UMA SOLICITAÇÃO DA UNESCO EM $1948^{220}$}

"Toda reforma interior e toda mudança para melhor dependem exclusivamente da aplicação do nosso próprio esforço”. (Kant)

\section{DA JUSTIFICATIVA DO ANEXO}

O presente anexo traz um trecho da resposta dada a UNESCO ${ }^{221}$, em 1948, pelo psiquiatra suíço Carl Gustav Jung, fundador da chamada psicologia analítica ou junguiana, que introduz na psicologia os conceitos de inconsciente coletivo $^{222}$, sincronicidade e individuação.

A escolha do mencionado anexo fundamenta-se na temática abordada no trabalho através da investigação kantiana sobre a paz à luz do progresso moral da $\underline{\text { humanidade }}^{223}$ e sua influência nos argumentos apresentados por Jung.

Importante dizer que, Jung, era um leitor entusiasta de Kant. Tanto que, o psiquiatra suíço chegou a declarar em 1941 que, epistemologicamente, apoiava-se no filósofo.

Assim sendo, o ponto de partida da investigação junguiana no tocante a alteração da disposição humana em prol da paz mundial, coincide com a de Kant. No sentido de que ambos partem da crença de que a mente (racionalidade) em si, e

\footnotetext{
${ }^{220} \mathrm{JUNG}$, Carl Gustav. Técnicas para uma alteração da disposição humana em prol da paz mundial. Tradução e Adaptação: Petho Sandor. Resposta a uma solicitação da UNESCO em 1948. São Paulo: Sedes Sapientae (arquivos), 2000.

${ }^{221}$ A UNESCO é uma agência especializada do Sistema das Nações Unidas.

${ }^{222} \mathrm{Em}$ apertada síntese e de acordo com a teoria desenvolvida por Jung, o "inconsciente coletivo" é a camada mais profunda da mente humana. De acordo com a teoria analítica, a mente seria constituída pelos materiais que foram herdados geneticamente, além dos chamados traços funcionais, tais como as imagens virtuais que seriam comuns a todos os seres humanos. O "inconsciente coletivo junguiano" também é atrelado as pré-disposições funcionais de organização do psiquismo, comparando-se nesse sentido às condições a priori da experiência, da teoria kantiana.

${ }^{223}$ Progressão que se daria por meio de mudanças operadas primeiramente no âmbito individual de cada ser humano, como parte de um todo, para depois refletir na coletividade, podendo-se aqui entender por coletividade as mais diferentes nações.
} 
não o mundo além dela, é o objeto mais imediato da percepção, e que tudo o que alegamos conhecer é de certa maneira dela derivado.

\section{EXTRATO $^{224}$ DA RESPOSTA DE JUNG A UNESCO}

Uma nação é a soma de seus indivíduos. O "caráter nacional” corresponde à média moral dos indivíduos. Ninguém está imune contra um "mal" nacionalmente difundido.

No entanto, a imunidade ao mal nacionalmente difundido, depende inteiramente da existência de uma minoria dominante, ou seja, depende da existência de indivíduos imunes e, portanto, capazes de combater o poderoso efeito sugestivo da aparente possibilidade de satisfação dos desejos individuais. Jung assevera que, caso os governantes (liderança da nação) não sejam imunes, inevitavelmente serão vítimas de seu próprio poder.

A cobiça acumulada de uma nação será totalmente incontrolável se não for contrarrestada por todos os meios de poder de natureza cívica e militar à disposição de um governo.

Com apoio nas premissas enunciadas, Jung faz duas sugestões:

1) Divulgar as ideias acima em círculos de debates que poderiam influenciar aqueles poucos em condições de chegar às suas próprias deduções e;

2) Propiciar uma oportunidade aos indivíduos que adotam a convicção de que a sua própria disposição necessita ser revista, ou seja, um tratamento individual analítico.

Por óbvio, "alterar a disposição" é uma noção bastante indeterminada. Assim sendo, deve ser salientado que, sob tal denominação, entende-se uma transmutação fomentada pela integração de conteúdos anteriormente inconscientes, à consciência. Com tal acréscimo ocorre inevitavelmente uma alteração, como tal bem percebível, e que nunca é "neutra".

\footnotetext{
${ }^{224}$ Tentou-se com a feitura do extrato impor uma linguagem mais familiar ao direito internacional retirandose as questões específicas psicológicas que permeiam o original. Importante dizer que a tradução contém muitos vocábulos jurídicos que padecem de precisão.
} 
A alteração da disposição humana em prol da paz é essencialmente uma expansão da consciência, dependendo inteiramente do caráter do indivíduo a forma que ao fim tomará. Quem sabe?

O desenvolvimento progressivo da consciência do ser humano e por conseguinte da humanidade como um todo. 